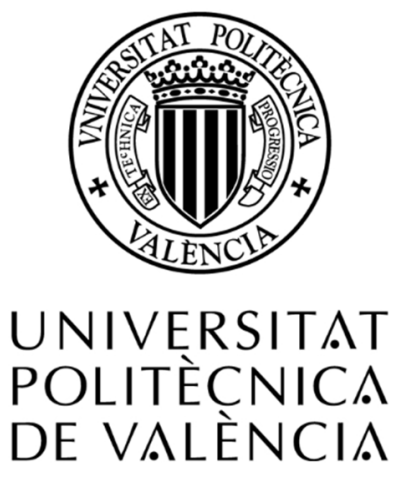

\title{
SELECTION FOR OVULATION RATE AND LITTER SIZE IN RABBITS
}

\author{
Ph.D. Thesis by \\ Ahmed Yehia Badawy Elmoghazy \\ Supervisors \\ Dr. María Antonia Santacreu Jerez \\ Dr. Rosa Peiró Barber \\ Instituto de Ciencia y Tecnología Animal \\ Universidad Politécnica de Valencia
}

Valencia, September 2016 


\title{
SELECTION FOR OVULATION RATE AND LITTER SIZE IN RABBITS
}

\begin{abstract}
This thesis has been submitted in fulfillment of the requirements for the degree of doctor of philosophy in Animal Breeding and Genetics at the Polytechnic University of Valencia
\end{abstract}

\section{By}

\section{Ahmed Yehia Badawy Elmoghazy}

Signature

Thesis Supervisors

Dr. María Antonia Santacreu Jerez

Signature
Dr. Rosa Peiró Barber

Signature 
"He who leaves his home in search of knowledge, walks in the path of GOD" Prophet Muhammad

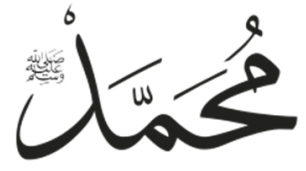


In this world

You have to be a human

But you must know and realize that the pain of humanity is not endurable

Such pain may kill you

Ahmed Yehia 
Ta My Own Family,

My Lavely wife Manay

My Sans Youssef and Mahamed

My Daughter Layra

Lave you all. 


\section{ACKNOWLEDGEMENTS}

Thanks to ALLAH (GOD),

Thanks to ALLAH for being always with me during my life and giving me the ability to finish this work,

Thanks to ALLAH for giving me more than I hope and want,

Thanks to ALLAH being always there when nobody else was.

I would like to express my sincere thanks and gratitude to my supervisors Dra. María Antonia Santacreu and Dra. Rosa Peiró Barber for their continuous support of my Ph.D. study and related research, for their patience, motivation, and immense knowledge. Their guidance helped me in all the time of research and writing of this thesis. I could not have imagined having a better advisors and mentors for my Ph.D. study. Toñi, I really appreciate everything you did for me especially during the period of learning the procedure of laparoscopy. Rosa, I really have learned a lot from you, especially the statistical analysis using different programs and also handling of databases.

Besides my supervisors, I would like to thank all the members of Animal Genetic Improvement Group. In Particular Prof. Dr. Agustin Blasco (head of our working group), for his support and advice all the time and also for taking me into the Bayesian statistics world and putting me in a new area of scientific research. Agustin, I really cannot find words to express my appreciation. Prof. Dr. Manuel Baselga, for his insightful comments, continuous encouragement and advice. Manolo, I really enjoyed attending courses with you and I have learned a lot from you. Many thanks for Prof. Dr. Pilar Hernández for her interest and support all the time, Pilar, I will never forget your words supporting me.

Toñi, Rosa, Agustin, Manolo and Pilar, it was an honor working with you all. Additionally, My thanks to Prof. Dr. Juan José Pascual for his continuous encouragement. Special thanks to Federico Pardo Bernat for his effort with me during my work in the farm. Fede, I have learned a lot from you and it was an honor working with you.

My deepest and sincere thanks to my friends Vero, Cris, Marina, Carlos, Samuel, Jesus, Judith and José for their encouragement all the time and thanks for let 
me being one of you. Vero, I am very thankful for you accompanying me during my work in both farm and laboratory.

I would like to express my thanks to my Egyptian friends here in Spain Mohamed Ragab, Ayman El-Nagar, Tarek Sloma, Saif Agha, Mohamed Maher, Mohamed Alaa, Abdallah Abd-Elazeem, Ahmed Ezzat, Ahmed Fawzy, Abdelsattar Gamal, Ragab Fayez, Abdel-Rahman Hussein, Ramy Shaltout, Abeer El-Sayed, Hanan Sadek and beautiful couple Mostafa and Suzan for their support and encouragement.

Also, my sincere thanks goes to my professors and colleagues in the Animal production department, Faculty of Agriculture, Suez Canal University, Egypt for their support. My special thanks to Prof. Dr. Ahmed Abdel-Ghany for his interest and support all the time, Prof. Dr. Hani Sabri, Prof. Dr. Mounir Khattab and Dr. Mohamed El-Zarei.

My grateful thanks to the Cultural Affairs and Mission Sector, Egyptian Ministry of Higher Education for supporting me with a scholarship during my first two years. My thanks to all the members of the Egyptian Cultural and Educational Bureau in Madrid, Prof. Dr. Basem Daoud (the present Cultural Counselor), Prof. Dr. El Sayed Soheim (the ex-cultural Counselor) and Mr. Hani El-Maadawi for their support and providing me the right ambience and removing all obstacles which allowed and gave me the opportunity for full-time scientific research.

Thanks to the Spanish Interministerial Commission of Science and Technology for supporting our project "CICYT- AGL2011- 29831-C03-01" and Generalitat Valenciana research program for their fund (Prometeo 2009/125).

Last but not the least, I would like to express the deepest thanks to my big family, to the people who are the reason of what I become today, my father, my mother, my father and mother in law and my lovely sisters (Iman \& Hanan) for supporting me all the time throughout my study and my life in general. 


\section{INDEX}

$\begin{array}{lr}\text { ABSTRACT } & \text { I } \\ \text { RESUMEN } & \text { V } \\ \text { RESUM } & \text { IX }\end{array}$

CHAPTER 1: Introduction

1.1. Rabbit production 1

1.1.1. Rabbit meat characteristics 1

1.1.2. Rabbit meat production 2

1.2. Genetic improvement in rabbits 3

1.2.1. Selection for litter size 5

1.2.1.1. Genetic parameters 5

1.2.1.2. Response to selection for litter size 8

1.2.2. Litter size components: ovulation rate and prenatal survival 11

1.2.2.1. Ovulation rate 11

Ovulation process 11

Estimation of ovulation rate $\quad 13$

$\begin{array}{ll}\text { 1.2.2.2. Prenatal survival. } & 14\end{array}$

Embryonic and foetal development 14

First stages of development until implantation $\quad 14$

Placentation and late stages of gestation 15

Causes and distribution of prenatal mortality 17

Estimation of prenatal survival 19

$\begin{array}{ll}\text { 1.2.2.3. Selection for ovulation rate } & 19\end{array}$

Genetic parameters 20

Response to selection $\quad 22$

High ovulation rate and prenatal mortality 22

1.2.2.4. Selection for uterine capacity 25

1.2.2.5. Selection for ovulation rate and litter size 28

1.3. References 29

CHAPTER 2: Objectives

2.1. Objectives 
CHAPTER 3: Selection for Ovulation Rate and Litter Size Using Independent Levels in Rabbits: Genetic Parameters, Direct and Correlated Responses on Reproductive Traits $\quad 47$

3.1. Abstract 49

3.2. Introduction 50

3.3. Materials and methods 51

3.3.1. Animals and experimental design 51

3.3.2. Traits 52

3.3.3. Statistical Analysis $\quad 53$

3.4. Results and discussion $\quad 55$

3.4.1. Genetic parameters 56

3.4.1.1. Heritability 56

3.4.1.2. Repeatability $(r) \quad 59$

3.4.1.3. Genetic correlations between litter size and other traits 60

3.4.1.4. Genetic correlations between ovulation rate and other traits 62

3.4.1.5. Correlations between permanent effects 63

3.4.1.6. Phenotypic correlations 64

3.4.2. Response to selection $\quad 68$

3.4.2.1. Selection for ovulation rate 68

3.4.2.2. Selection by independent culling levels for ovulation rate $\begin{array}{ll}\text { and litter size } & 71\end{array}$

3.5. Conclusion 74

3.6. References 74

CHAPTER 4: Selection for Ovulation Rate and Litter Size Using Independent Levels in Rabbits: Genetic Parameters and Correlated Responses on Growth Traits 81

4.1. Abstract 83

4.2. Introduction 84

$\begin{array}{lr}\text { 4.3. Materials and methods } & 85\end{array}$

4.3.1. Animals and experimental design 85

4.3.2. Traits 87

$\begin{array}{ll}\text { 4.3.3. Statistical Analysis } & 87\end{array}$ 
4.4. Results and discussion $\quad 89$

4.4.1. Genetic parameters 90

4.4.1.1. Heritability 90

4.4.1.2. Maternal effect $\left(m^{2}\right)$ and common litter effect $\left(c^{2}\right) \quad 91$

4.4.1.3. Correlations between reproductive traits and growth 93 traits

4.4.1.4. Response to selection 96

4.5. Conclusion 98

4.6. References 98

CHAPTER 5: Effect of Increased Ovulation Rate on Embryo and Foetal Survival as A Model for Selection by Ovulation Rate in Rabbits 103

5.1. Abstract 105

5.2. Introduction 107

$\begin{array}{ll}\text { 5.3. Materials and methods } & 108\end{array}$

5.3.1. Animals 108

$\begin{array}{ll}\text { 5.3.2. Treatment with eCG } & 108\end{array}$

$\begin{array}{ll}\text { 5.3.3. Traits } & 108\end{array}$

$\begin{array}{ll}\text { 5.3.4. Statistical Analyses } & 109\end{array}$

$\begin{array}{ll}\text { 5.4. Results and discussion } & 110\end{array}$

5.4.1. Ovulation rate, number of implanted embryos and foetuses 112

5.4.2. Survival rates 113

5.4.3. Placenta and foetus weight 116

$\begin{array}{ll}\text { 5.5. Conclusion } & 118\end{array}$

$\begin{array}{ll}\text { 5.6. References } & 119\end{array}$

CHAPTER 6: General Discussion

$\begin{array}{ll}\text { 6.1. Background } & 123\end{array}$

$\begin{array}{ll}\text { 6.2. Relevant findings } & 125\end{array}$

6.2.1. Selection for ovulation rate 125

High ovulation rate and prenatal mortality 126

Selection for ovulation rate and litter size $\quad 128$

$\begin{array}{ll}\text { 6.3. References } & 131\end{array}$ 


\section{CHAPTER 7: Conclusions}

Genetics and environmental parameters 137

Response to selection 137

High ovulation rate and prenatal mortality 138 


\section{LIST OF TABLES}

\section{CHAPTER 1}

Table 1.1. Comparative composition of rabbit, chicken, beef and pig meat.

Table 1.2. Heritability $\left(h^{2}\right)$ and repeatability $(r)$ estimates for litter size traits (litter size (LS, total number of kits born), number of kits born alive (NBA), number of kits at weaning (NW) and number of rabbits at marketing (NM)) in different rabbit lines.

Table 1.3. Direct response in number of kits at weaning (NW) or number of kits born alive (NBA) estimated per generation $(G)$ in rabbits.

Table 1.4. Correlated response in litter size (LS, total number of kits born), number of kits born alive (NBA), number of rabbits at marketing $(\mathrm{NM})$, ovulation rate (OR, ova) and prenatal survival (PS) estimated per generation in rabbits after selection for litter size at weaning (NW).

Table 1.5. Chronology of the major events observed from fertilization until implantation in rabbit.

Table 1.6. Heritability $\left(h^{2}\right)$ estimates for ovulation rate in different species.

Table 1.7. Genetic correlation $\left(r_{g}\right)$ estimates between ovulation rate and other litter size components in different species.

Table 1.8. Direct response per generation in ovulation rate (OR, ova) and correlated response in litter size (LS, total number of kits born), number of kits born alive (NBA), number of implanted embryos (IE), prenatal survival (PS) and foetal survival (FS) estimated per generation in rabbits, pigs and mice.

Table 1.9. Direct response in uterine capacity (UC) and correlated response in ovulation rate $(\mathrm{OR}$, ova), litter size (LS, total number of kits born) and prenatal survival (PS) after selection for increased uterine capacity in rabbits, pigs and mice. 


\section{CHAPTER 3}

Table 3.1. Descriptive analysis for ovulation rate (OR, ova), number of implanted embryos (IE), number of live foetus at 12 days of gestation ( $\left.\mathrm{LF}_{12}\right)$, litter size (LS, total number of kits born), number of kits born alive (NBA), number of kits born dead (NBD), number of kits at weaning (NW), number of rabbits at marketing (NM), embryo survival (ES), foetal survival (FS) and prenatal survival (PS).

Table 3.2. Features of the marginal posterior distributions of the heritability $\left(h^{2}\right)$ of ovulation rate (OR), number of implanted embryos (IE), number of live foetus at 12 days of gestation $\left(\mathrm{LF}_{12}\right)$, litter size (LS, total number of kits born), number of kits born alive (NBA), number of kits born dead (NBD), number of kits at weaning (NW) and number of rabbits at marketing (NM).

Table 3.3. Features of the marginal posterior distributions of the heritability $\left(h^{2}\right)$ of embryonic survival (ES), foetal survival (FS) and prenatal survival (PS).

Table 3.4. Features of the marginal posterior distributions of the repeatability (r) for ovulation rate (OR), number of implanted embryos (IE), number of live foetus at 12 days of gestation $\left(\mathrm{LF}_{12}\right)$, embryo survival (ES), litter size (LS, total number of kits born), number of kits born alive (NBA), number of kits born dead (NBD), number of kits at weaning $(\mathrm{NW})$ and number of rabbits at marketing (NM).

Table 3.5. Features of the marginal posterior distributions of the genetic correlation $\left(\boldsymbol{r}_{\boldsymbol{g}}\right)$ between litter size (LS, total number of kits born) and ovulation rate (OR), number of implanted embryos (IE), number of live foetus at 12 days of gestation $\left(\mathrm{LF}_{12}\right)$, number of kits born alive (NBA), number of kits born dead (NBD), number of kits at weaning $(\mathrm{NW})$, number of rabbits at marketing (NM), embryo survival (ES), foetal survival (FS) and prenatal survival (PS). 
Table 3.6. Features of the marginal posterior distributions of the genetic correlation $\left(\boldsymbol{r}_{\boldsymbol{g}}\right)$ between ovulation rate $(\mathrm{OR})$ and number of implanted embryos (IE), number of live foetus at 12 days of gestation $\left(\mathrm{LF}_{12}\right)$, number of kits born alive (NBA), number of kits born dead (NBD), number of kits at weaning (NW), number of rabbits at marketing (NM), embryo survival (ES), foetal survival (FS) and prenatal survival (PS).

Table 3.7. Features of the marginal posterior distributions of the correlation between permanent effects ( $\left.r_{\text {permanent }}\right)$ for litter size (LS, total number of kits born) and ovulation rate (OR) with number of implanted embryos (IE), number of live foetus at 12 days of gestation ( $\left.\mathrm{LF}_{12}\right)$, embryo survival (ES), number of kits born alive (NBA), number of kits born dead (NBD), number of kits at weaning (NW) and number of rabbits at marketing (NM).

Table 3.8. Features of the marginal posterior distributions of the phenotypic correlation $\left(\boldsymbol{r}_{\boldsymbol{p}}\right)$ between litter size (LS, total number of kits born) and ovulation rate (OR), number of implanted embryos (IE), number of live foetus at 12 days of gestation $\left(\mathrm{LF}_{12}\right)$, number of kits born alive (NBA), number of kits born dead (NBD), number of kits at weaning (NW), number of rabbits at marketing (NM), embryo survival (ES), foetal survival (FS) and prenatal survival (PS).

Table 3.9. Features of the marginal posterior distributions of the phenotypic correlation $\left(\boldsymbol{r}_{\boldsymbol{p}}\right)$ between ovulation rate (OR) and number of implanted embryos (IE), number of live foetus at 12 days of gestation $\left(\mathrm{LF}_{12}\right)$, number of kits born alive (NBA), number of kits born dead (NBD), number of kits at weaning (NW), number of rabbits at marketing (NM), embryo survival (ES), foetal survival (FS) and prenatal survival (PS). 


\section{CHAPTER 4}

Table 4.1. Descriptive statistics for weaning weight (WW, kg), marketing weight (MW, kg) and growth rate (GR, $\mathrm{kg}$ ) after selection for six generations for ovulation rate and 11 generations for ovulation rate and litter size.

Table 4.2. Features of marginal posterior distributions of the heritability $\left(h^{2}\right)$ of weaning weight (WW), marketing weight (MW) and growth rate (GR) during fattening period.

Table 4.3. Features of marginal posterior distributions of proportion of the maternal effect variance $\left(\mathrm{m}^{2}\right)$ respect to phenotypic variance for weaning weight (WW), marketing weight (MW) and growth rate (GR).

Table 4.4. Features of marginal posterior distributions of the proportion of the common litter effect variance $\left(c^{2}\right)$ respect to phenotypic variance for weaning weight (WW), marketing weight (MW) and growth rate (GR).

Table 4.5. Features of marginal posterior distributions of the genetic correlation $\left(r_{g}\right)$ of litter size (LS) and ovulation rate (OR) with weaning weight (WW), marketing weight (MW) and growth rate (GR).

Table 4.6. Features of the marginal posterior distributions of the correlation between permanent effects ( $r_{\text {permanent }}$ ) for litter size (LS) and ovulation rate (OR) with weaning weigh (WW), marketing weight (MW) and growth rate (GR).

Table 4.7. Features of marginal posterior distributions of the phenotypic correlation $\left(r_{p}\right)$ of litter size (LS) and ovulation rate (OR) with weaning weight (WW), marketing weight (MW) and growth rate (GR).

\section{CHAPTER 5}

Table 5.1. Raw mean, standard deviation (SD) and coefficient of variation (CV) for studied traits for untreated females. 
Table 5.2. Mean of the posterior distribution for treated and untreated females and features of the marginal posterior distributions of the differences between treated and untreated females for ovulation rate (OR, ova), ovaries weight (OW, g), number of implanted embryos (IE), number of live foetuses at 12 day of gestation $\left(\mathrm{LF}_{12}\right)$, total number of foetus at 18 day of gestation $\left(\mathrm{TF}_{18}\right)$, and number of live foetuses at 18 day of gestation $\left(\mathrm{LF}_{18}\right)$.

Table 5.3. Mean of the posterior distribution for treated and untreated females and features of the marginal posterior distributions of the differences between treated and untreated females in embryo survival (ES), foetal survival of live foetuses at both $12\left(\mathrm{FS}_{\mathrm{LF} 12}\right)$ and 18 (FS $\left.\mathrm{LF18}_{\mathrm{L}}\right)$ days of gestation, foetal survival between 12 and 18 days of gestation $\left(\mathrm{FS}_{\mathrm{LF} 18 / \mathrm{LF} 12}\right)$, prenatal survival of live foetuses at 18 day of gestation (PS $\left.\mathrm{PF}_{\mathrm{L} 18}\right)$.

Table 5.4. Mean of the posterior distribution for treated and untreated females and features of the marginal posterior distributions of the differences between treated and untreated females in live foetus weight (LFWm, g), live foetus placental weight (LFPWm, g), and dead foetus placental weight (DFPWm, g) at 18 day of gestation.

Table 5.5. Mean of the posterior distribution for treated and untreated females and features of the marginal posterior distributions of the differences between treated and untreated females in the variability on live foetus weight (LFWv, g) and variability on live foetus placental weight (LFPWv, g) at 18 day of gestation. 



\section{LIST OF FIGURES}

\section{CHAPTER1}

Figure 1.1. World production of rabbit meat (tonnes) from 1961 to 2013. (FAO-STAT, 2015).

Figure 1.2. Genetic improvement process diagram.

Figure 1.3. Ovulation stimulation process in rabbit.

Figure 1.4. Description of the laparoscopy procedure performed at day 12 of gestation to record ovulation rate and number of implanted embryos. (A) Prepare and anesthetizing the doe. (B) Ready doe to do laparoscopy (in trendelenburg position). (C) Visualization of foetus. (D) Corpora lutea.

Figure 1.5. Picture of rabbit foetus and its placenta near term.

Figure 1.6. Percentage of embryonic mortality (EM) and foetal mortality (FM) in rabbits during gestation. Implantation occurs at day seven of gestation.

\section{CHAPTER 3}

Figure 3.1. Genetic trends for ovulation rate (OR) and litter size (LS) of ORLS line, initially selected for ovulation rate at second gestation from generation 0 to 6 and later for ovulation rate at second gestation and litter size of the first two parities from generation 7 to 17 .

Figure 3.2. Genetic trends for number of implanted embryos (IE) and number of live fetuses at 12 days of gestation $\left(\mathrm{LF}_{12}\right)$ of OR-LS line, initially selected for ovulation rate at second gestation from generation 0 to 6 and later for ovulation rate at second gestation and litter size of the first two parities from generation 7 to 17 .

Figure 3.3. Genetic trends for embryo survival (ES), foetal survival (FS) and prenatal survival (PS) of OR-LS line, initially selected for ovulation rate at second gestation from generation 0 to 6 and later for ovulation rate at second gestation and litter size of the first two parities from generation 7 to 17 . 
Figure 3.4. Genetic trends for number of kits born alive (NBA), number of kits born dead (NBD), number of kits at weaning (NW) and number of rabbits at marketing (NM) of OR-LS line, initially selected for ovulation rate at second gestation from generation 0 to 6 and later for ovulation rate at second gestation and litter size of the first two parities from generation 7 to 17 .

\section{CHAPTER 4}

Figure 4.1. Genetic trends for weaning weight (WW; kg), marketing weight (MW; kg) and growth rate (GR; kg) of OR-LS line, initially selected for ovulation rate at second gestation from generation 0 to 6 and later for ovulation rate at second gestation and litter size of the first two parities from generation 7 to 17 . 


\section{LIST OF ABBREVIATIONS}

\begin{tabular}{|c|c|}
\hline B-R & Best Linear Unbiased Prediction-Restricted Maximum Likelihood \\
\hline$c^{2}$ & $\begin{array}{l}\text { Proportion of the common litter effect variance respect to phenotypic } \\
\text { variance }\end{array}$ \\
\hline Cryo-CP & Cryopreserved control population \\
\hline $\mathrm{CV}$ & Coefficient of variation \\
\hline $\mathrm{D}$ & Posterior mean of differences between treated and untreated females \\
\hline DFPWm & Dead foetus placental weight \\
\hline eCG & equine chorionic gonadotropin \\
\hline EM & Embryonic mortality \\
\hline ES & Embryo survival \\
\hline FM & Foetal mortality \\
\hline FS & Foetal survival \\
\hline FSH & Follicle-stimulating hormone \\
\hline $\mathrm{FS}_{\mathrm{LF} 12}$ & Foetal survival of live foetuses at 12 days of gestation \\
\hline $\mathrm{FS}_{\mathrm{LF} 18}$ & Foetal survival of live foetuses at 18 days of gestation \\
\hline $\mathrm{FS}_{\mathrm{LF} 18 / \mathrm{LF} 12}$ & Foetal survival between 12 and 18 days of gestation \\
\hline G & Generation \\
\hline $\mathrm{GnRH}$ & Gonadotropin-releasing hormone \\
\hline GR & Growth rate \\
\hline$h^{2}$ & Heritability \\
\hline $\mathrm{HPD}_{95 \%}$ & High posterior density interval at $95 \%$; \\
\hline IE & Number of implanted embryos \\
\hline $\mathrm{LF}_{12}$ & Number of live foetuses at 12 days of gestation \\
\hline $\mathrm{LF}_{18}$ & Number of live foetuses at 18 days of gestation \\
\hline LFPWm & Live foetus placental weight \\
\hline LFPWv & Variability on live foetus placental weight \\
\hline LFWm & Live foetus weight \\
\hline LFWv & Variability on live foetus weight \\
\hline LH & Luteinizing hormone \\
\hline LS & Litter size, total number of kits born \\
\hline$m^{2}$ & Proportion of the maternal effect variance respect to phenotypic variance \\
\hline Max. & Maximum \\
\hline
\end{tabular}




$\begin{array}{ll}\text { Min. } & \text { Minimum } \\ \text { MW } & \text { Marketing weight } \\ \text { NBA } & \text { Number of kits born alive } \\ \text { NBD } & \text { Number of kits born dead } \\ \text { NM } & \text { Number of rabbits at marketing } \\ \text { NW } & \text { Number of kits at weaning } \\ \text { OR } & \text { Ovulation rate } \\ \text { OW } & \text { Ovaries weight } \\ P & \text { Probability } \\ \text { PS } & \text { Prenatal survival } \\ \text { PS } & \text { PF18 } \\ r & \text { Repenatal survival of live foetuses at } 18 \text { days of gestation } \\ r_{g} & \text { Genetic correlation } \\ r_{p} & \text { Phenotypic correlation } \\ r_{p e r m a n e n t} & \text { Correlation between permanent effects } \\ \text { SD } & \text { Standard deviations } \\ \text { TF } 18 & \text { Total number of foetuses at 18 days of gestation } \\ \text { UC } & \text { Uterine capacity } \\ \text { U-CP } & \text { Unselected control population } \\ \text { WW } & \text { Weaning weight }\end{array}$




\section{ABSTRACT}

The general aim of this thesis was to evaluate the productive performance of a rabbit line (OR-LS) selected by ovulation rate during first 6 generations (period 1), and later by ovulation rate (OR) and litter size (LS) during 11 generations using independent culling levels (period 2). Genetic parameters, direct response for OR and LS and the correlated response for embryo (ES), foetal (FS) and prenatal survival (PS) were estimated. Also, the correlated response on growth rate (GR), weaning (WW) and marketing weight (MW) were estimated. Lately, it was studied the magnitude and timing of embryo and early foetal survival in females with high ovulation rate using hormonal treatment as a model for selection by ovulation rate.

The objective of chapter 3 was to estimate the genetic parameters of the productive traits and the response to selection by OR and LS of OR-LS line. For traits analysis, Bayesian methods were used. Heritability values of litter size traits were low, $0.10,0.07,0.07$ and 0.07 for number of total born (LS), number of born alive (NBA), number of kits at weaning (NW) and marketing (NM), respectively, while it was 0.14 for number of born dead (NBD). Heritability for ovulation rate (OR) obtained was moderate $(0.25)$, while it was low $(0.13$ and 0.14$)$ for number of implanted embryos (IE) and number of live foetuses at 12 days of gestation $\left(\mathrm{LF}_{12}\right)$, respectively. Low heritability values for survival traits were found, 0.09 for embryo survival (ES), 0.16 for foetal survival (FS) and 0.14 for prenatal survival (PS). Repeatability estimates were low for all litter size traits, ranged from 0.14 to 0.17 except for NBD (0.24). For OR, IE, $\mathrm{LF}_{12}$, repeatability values were moderate $(0.30,0.22$ and 0.22 , respectively) and low for ES (0.18). In the second period, after 11 generations of selection by OR and LS, a genetic response of 0.17 kits per generation for LS was achieved. This response was 
higher than the obtained in period 1 ( 0.07 kits per generation), in which just selection by OR was performed. The opposite effect was found for OR; the highest response for OR appeared in the first period ( 0.24 ova per generation) versus the second period $(0.17$ ova per generation). This reduction in OR response can be due to the decrease in selection differential during the second period of selection. Since high genetic correlations were obtained for LS and other litter size traits, a positive correlated response was observed for NBA, NW and $\mathrm{NM}(0.12,0.12$ and 0.11 kits per generation, respectively) in the second period. In the first period, no correlated response on ES was observed and a decrease in FS (-0.04) was found. Nevertheless, in the second period a correlated response on PS appeared due to an improvement in both ES (0.04) and FS (0.03). Summarizing, the improvement in litter size in the second period is due to an increase in ovulation rate as well as an increase in prenatal survival.

The objective of chapter 4 was to study the correlated response on growth traits in the OR-LS line in both periods of selection, the selection by OR during six generations and the selection by independent levels by OR and LS during 11 generations. The heritability estimates were low for weaning weight (WW), marketing weight (MW) and growth rate (GR), 0.09, 0.13 and 0.14 , respectively. The estimated genetic correlations of WW, GR and MW with LS were around zero and with OR were positive and from low $(0.19)$ to moderate $(0.38)$. The positive moderate genetic correlation estimated between OR and MW could explain the correlated response found in MW. Correlated response on WW could be explained by positive and high genetic correlation between MW and WW.

Selection for ovulation rate in prolific specie has not improved litter size due to an increase in prenatal mortality. Most of the mortality was observed in the foetal period. The aim of chapter 5 was to investigate magnitude and timing of embryo and 
early foetal survival in females with high ovulation rate using hormonal treatment as a model for selection by ovulation rate, as it was commented before. Two groups of females (treated and untreated) were used. Treated females were injected with $50 \mathrm{IU}$ eCG 48 hours before mating. Females were slaughtered at day 18 of gestation. Ovulation rate (OR), number of implanted embryos (IE), number of live foetuses at 12 and $18 \mathrm{~d}\left(\mathrm{LF}_{12}\right.$ and $\mathrm{LF}_{18}$, respectively) were recorded. Besides, embryo survival (ES= IE/OR), foetal survival at $18 \mathrm{~d}$ of gestation $\left(\mathrm{FS}_{\mathrm{LF} 18}=\mathrm{LF}_{18} / \mathrm{IE}\right)$ and foetal survival between 12 and $18 \mathrm{~d}$ of gestation $\left(\mathrm{FS}_{\mathrm{LF} 18 / \mathrm{LF} 12}=\mathrm{LF}_{18} / \mathrm{LF}_{12}\right)$ and prenatal survival $\left(\mathrm{PS}_{\mathrm{LF} 18}=\mathrm{LF}_{18} / \mathrm{OR}\right)$ were estimated. For each female, the mean and variability of the weight for live foetuses (LFW and VLFW, respectively) and their placentas (LFPW and VLFPW, respectively) were calculated. Treated females had a higher ovulation rate (3.02 ova) than untreated females with a probability of 0.99 . An increase in the differences (D) between treated and untreated females was observed from implantation to day 18 of gestation $\left(\mathrm{D}=-0.33,-0.70\right.$ and -1.28 for $\mathrm{IE}, \mathrm{LF}_{12}$ and $\mathrm{LF}_{18}$, respectively). These differences had a low accuracy and the probability that treated females had a lower number of foetuses also increased along gestation $(\mathrm{D}=0.60,0.70$ and 0.86 for IE, $\mathrm{LF}_{12}$ and $\mathrm{LF}_{18}$, respectively). According to the previous results for $\mathrm{OR}$ and $\mathrm{LF}_{18}$, treated females showed a lower survival rate from ovulation to $18 \mathrm{~d}$ of gestation $(D=-0.12$, $\mathrm{P}=0.98$ for $\left.\mathrm{PS}_{\mathrm{LF} 18}\right)$. Treated females also had lower embryo and foetal survival $(\mathrm{D}=-$ 0.10 and $\mathrm{P}=0.94$ for $\mathrm{ES}$ and $\mathrm{D}=-0.08$ and $\mathrm{P}=0.93$ for $\left.\mathrm{FS}_{\mathrm{LF} 18}\right)$. Main difference in foetal survival appeared from day 12 to 18 of gestation $\left(\mathrm{D}=-0.09\right.$ and $\mathrm{P}=0.98$ for $\left.F S_{L F 18 / 12}\right)$. Unexpectedly, treated females showed similar foetus weight and higher foetal placenta weight than untreated females $(\mathrm{D}=0.25 \mathrm{~g}, \mathrm{P}=0.98)$ and lower variability for these traits $(\mathrm{D}=-0.02 \mathrm{~g}, \mathrm{P}=0.72$ for $\mathrm{VLFW}$ and $\mathrm{D}=-0.05 \mathrm{~g}, \mathrm{P}=0.83$ for VLFPW). These results are not related to a lower number of IE or $\mathrm{LF}_{18}$. Then, the effect of increasing three ova in 
rabbits leads to a lower embryo and early foetal survival. It seems there is not a relationship between foetal mortality and foetus weight. 


\section{RESUMEN}

El objetivo general de esta tesis fue evaluar el tamaño de camada de una línea de conejo (línea OR-LS) seleccionada por tasa de ovulación durante las primeras seis generaciones (Periodo 1) y después por tasa de ovulación (OR) y el tamaño de camada (LS) durante 11 generaciones mediante el método de niveles independientes (Período 2). Se estimaron los parámetros genéticos, la respuesta directa para OR y la respuesta correlacionada en la supervivencia embrionaria (ES), fetal (FS) y prenatal (PS). Además, se estudió la respuesta correlacionada en los caracteres de crecimiento, peso al destete (WW), peso al sacrificio (MW) y ganancia de peso entre destete y sacrificio (GR). Por último, se estudió en qué momento del periodo fetal se produce la mortalidad cuando la tasa de ovulación se incrementa y cómo afecta al desarrollo del feto y de la placenta fetal en hembras con elevada tasa de ovulación. Para aumentar la tasa de ovulación se realizó un tratamiento hormonal como modelo para evaluar el efecto de la selección por tasa de ovulación.

El objetivo del capítulo 3 fue estimar los parámetros genéticos de los caracteres reproductivos y la respuesta a la selección por OR y LS mediante niveles independientes de línea OR-LS. Para el análisis de los caracteres se utilizaron métodos bayesianos. Los valores de heredabilidad de los caracteres del tamaño de camada fueron bajos. Estos valores fueron de 0.10, 0.07, 0.07 y 0.07 para número de nacidos totales (LS), nacidos vivos (NBA), número al destete (NW) y número al sacrificio (NM), respectivamente; mientras que fue de 0.14 para nacidos muertos (NBD). La heredabilidad estimada para OR fue moderada (0.25), mientras que fue baja (0.13 y 0.14) para el número de embriones implantados (IE) y el número de fetos vivos a los 12 días de gestación $\left(\mathrm{LF}_{12}\right)$, respectivamente. Para los caracteres de 
supervivencia se obtuvieron valores bajos de heredabilidad, 0.09 para ES, 0.16 para FS y 0.14 para PS. Las estimaciones de la repetibilidad fueron bajas para todos los caracteres del tamaño de camada, variaron de 0.14 a 0.17 , excepto para NBD que fue de 0.24 . Se encontraron valores moderados de repetibilidad para OR, IE y LF ${ }_{12},(0.30$, 0.22 y 0.22 , respectivamente), y bajos para ES (0.18). En el segundo periodo, tras 11 generaciones de selección por OR y LS, se obtuvo una respuesta genética de 0.17 gazapos por generación para LS. Esta respuesta fue mayor que la obtenida en el periodo 1, 0.07 gazapos por generación, en el que solo se seleccionó por tasa de ovulación durante seis generaciones. En el caso de la tasa de ovulación, la mayor respuesta para OR fue en el primer periodo ( 0.24 óvulos por generación) versus $(0.17$ óvulos por generación) en el segundo periodo. Esta reducción en la respuesta de OR se puede atribuir a la disminución del diferencial de selección durante el segundo período de selección. Dada la alta correlación genética entre LS y otros caracteres del tamaño de camada, se observó una respuesta correlacionada positiva en NBA, NW y NM (0.12, 0.12 y 0.11 gazapos por generación, respectivamente) en el segundo periodo. En el primer periodo no se observa respuesta correlacionada en la supervivencia embrionaria y se produce una disminución de la supervivencia fetal (0.04). Sin embargo, en el segundo periodo se produce una respuesta correlacionada en la supervivencia prenatal que se debe a una mejora de la supervivencia embrionaria (0.04) y fetal (0.03). En resumen, la mejora del tamaño de camada en el segundo periodo se debe tanto a un aumento de la tasa de ovulación como a un aumento de la supervivencia prenatal.

El objetivo del capítulo 4 fue estudiar la respuesta correlacionada en los caracteres de crecimiento en la línea OR-LS en los dos periodos de selección, la selección por tasa de ovulación durante seis generaciones y la selección por niveles 
independientes por tasa de ovulación y tamaño de camada durante 11 generaciones, respectivamente. Las estimas de heredabilidad fueron bajas para los caracteres peso al destete (WW; 0.09), peso sacrificio (MW; 0.13) y ganancia de pesos durante el periodo de engorde (GR; 0.14). Las correlaciones genéticas estimadas de LS con WW, MW y GR fueron cercanas a cero; con la tasa de ovulación, las correlaciones fueron positivas y variaban de bajas a moderadas (de 0.19 a 0.38). La correlación genética moderada entre OR y MW podría explicar la respuesta correlacionada encontrada para MW. Por otra parte, la alta correlación entre MW y WW podría explicar la respuesta correlacionada obtenida para WW.

Dado que cuando se selecciona por tasa de ovulación no se mejora el tamaño de camada por un aumento de la mortalidad fetal, el objetivo de capítulo 5 fue estudiar en hembras con alta tasa de ovulación en qué momento se producen las mayores pérdidas fetales y cómo se ve afectado el desarrollo fetal. Para ello, de un total de 51 hembras, 24 hembras fueron pinchadas con 50 UI de eCG 48 horas antes de la cubrición para aumentar la tasa de ovulación. Las hembras tratadas tuvieron una tasa de ovulación 3,02 óvulos mayor que las no tratadas. Este aumento es similar a la respuesta obtenida tras diez generaciones de selección por tasa de ovulación. Debido a una mayor mortalidad embrionaria en las hembras tratadas, ambos grupos de hembras no presentaron diferencias para el número de embriones implantados (IE). A partir de la implantación hasta los 18 días de la gestación, la diferencia entre hembras tratadas y no tratadas aumentó $(-0.33,-0.70$ y -1.28 para $\mathrm{IE}$, número de fetos vivos a los 12 y 18 días de gestación $\left(\mathrm{LF}_{12}\right.$ y $\mathrm{LF}_{18}$, respectivamente)). Estas diferencias tenían una baja precisión y la probabilidad de que las hembras tratadas tuvieran un menor número de fetos fue aumentando a lo largo de la gestación $\left(0.60,0.70\right.$ y 0.86 para $\mathrm{IE}, \mathrm{LF}_{12}$ y $\mathrm{LF}_{18}$, respectivamente). 
De acuerdo con los resultados previos obtenidos para $\mathrm{OR}$ y $\mathrm{LF}_{18}$, las hembras tratadas mostraron una supervivencia más baja desde la ovulación hasta los 18 días de gestación (-0.12) y tuvieron una menor supervivencia embrionaria $(0.10)$ y fetal (0.08). Las principales diferencias en la supervivencia fetal aparecieron entre los días 12 y 18 de gestación (-0.09). Sin embargo, las hembras tratadas mostraron un peso de los fetos similar y mayor peso de la placenta fetal que las hembras no tratadas $(0.25$ gramos), además de una menor variabilidad en estos caracteres. Estos últimos resultados no están relacionados con un menor número de IE o número de fetos vivos a los 18 días de gestación. En conclusión, el aumento de la tasa de ovulación en conejos produce una menor supervivencia embrionaria y una menor supervivencia en las primeras etapas del desarrollo fetal. 


\section{RESUM}

L'objectiu general d'esta tesi va ser avaluar la millora de la grandària de ventrada d'una línia de conill (línia OR-LS) seleccionada per tasa d'ovulació durant les primeres sis generacions (Període 1) i després per tasa d'ovulació (OR) i la grandària de ventrada (LS) durant 11 generacions per mitjà del mètode de nivells independents (Període 2). Es van estimar els paràmetres genètics, la resposta directa per a OR i la resposta correlacionada en la supervivència embrionària (ES), fetal (FS) i prenatal (PS). A més, es va estudiar la resposta correlacionada en els caràcters de creixement, pes al deslletament (WW), pes al sacrifici (MW) i guany de pes entre el deslletament y el sacrifici (GR). Finalment, es va estudiar en quin moment del període fetal es produeix la mortalitat quan la tasa d'ovulació s'incrementa i com afecta el desenvolupament del fetus i de la placenta fetal.

L'objectiu del capítol 3 va ser estimar els paràmetres genètics dels caràcters reproductius i la resposta a la selecció per OR i LS per mitjà de nivells independents de línia OR-LS. Per a l'anàlisi dels caràcters es van utilitzar mètodes bayesians. Els valors d'heretabilitat dels caràcters de la grandària de ventrada van ser baixos. Estos valors van ser de $0.10,0.07,0.07$ i 0.07 per a nombre de nascuts totals (LS) i nascuts vius (NBA), nombre de deslletats (NW) i sacrificats (NM), respectivament; mentres que va ser de 0.14 per a nascuts morts (NBD) . L'heretabilitat estimada per a OR va ser moderada $(0.25)$, mentres que va ser baixa $(0.13$ i 0.14$)$ per al nombre d'embrions implantats (IE) i el nombre de fetus vius als 12 dies de gestació ( $\mathrm{LF}_{12}$ ) , respectivament. Per als caràcters de supervivència es van obtindre valors baixos d'heretabilitat, 0.09 per a ES, 0.16 per a FS i 0.14 per a PS. Les estimacions de la repetibilitat van ser baixes per a tots els caràcters de la grandària de ventrada, $i$ van 
variar de 0.14 a 0.17 , excepte per a NBD que va ser de 0.24 . Es van trobar valors moderats de repetibilitat per a OR, IE i $\mathrm{LF}_{12},(0.30,0.22$ i 0.22 , respectivament), i baixos per a ES (0.18). En el segon període, després d'11 generacions de selecció per OR i LS, es va obtindre una resposta genètica de 0.17 llorigons per generació per a LS. Esta resposta va ser major que l'obtinguda en el període 1, 0.07 llorigons per generació, en el que només es va seleccionar per tasa d'ovulació durant sis generacions. En el cas de la tasa d'ovulació, la major resposta per a OR va ser en el primer període ( 0.24 òvuls per generació) versus ( 0.17 òvuls per generació) en el segon període. Esta reducció en la resposta d'OR es pot atribuir a la disminució del diferencial de selecció durant el segon període de selecció. Donada l'alta correlació genètica entre LS i altres caràcters de la grandària de ventrada, es va observar una resposta correlacionada positiva en NBA, NW i NM $(0.12,0.12$ i 0.11 llorigons per generació, respectivament) en el segon període. En el primer període no s'observa resposta correlacionada en la supervivència embrionària i es produeix una disminució de la supervivència fetal (-0.04). No obstant això, en el segon període es produeix una resposta correlacionada en la supervivència prenatal que es deu a una millora de la supervivència embrionària (0.04) i fetal (0.03). En resum, la millora de la grandària de ventrada en el segon període es deu tant a un augment de la tasa d'ovulació com a un augment de la supervivència prenatal.

L'objectiu del capítol 4 va ser estudiar la resposta correlacionada en els caràcters de creixement en la línia OR-LS en els dos períodes de selecció, la selecció per tasa d'ovulació durant sis generacions i la selecció per nivells independents per tasa d'ovulació i grandària de ventrada durant 11 generacions, respectivament. Les estimes d'heretabilitat van ser baixes per als caràcters pes al deslletament (WW; 0.09), pes sacrifici (MW; 0.13) i guany de pes durant el període d'engreixament (GR; 0.14). 
Les correlacions genètiques estimades de LS amb WW, MW i GR van ser pròximes a zero; amb la tasa d'ovulació, les correlacions van ser positives i variaven de baixes a moderades (de 0.19 a 0.38 ). La correlació genètica moderada entre OR i MW podria explicar la resposta correlacionada trobada per a MW. D'altra banda, l'alta correlació entre MW i WW podria explicar la resposta correlacionada obtinguda per a WW.

Donat que quan se selecciona per tasa d'ovulació no es millora la grandària de ventrada per un augment de la mortalitat fetal, l'objectiu de capítol 5 va ser estudiar en femelles amb alta tasa d'ovulació en quin moment es van produir les majors pèrdues fetals i com es veu afectat el desenvolupament fetal. Per a això, d'un total de 51 femelles, 24 femelles van ser punxades amb 50 UI d'eCG 48 hores abans del cobriment per a augmentar la tasa d'ovulació. Les femelles tractades van tindre una tasa d'ovulació 3,02 òvuls major que les no tractades. Este augment és semblant a la resposta obtinguda després de deu generacions de selecció per tasa d'ovulació. A causa d'una major mortalitat embrionària en les femelles tractades, ambdós grups de femelles no van presentar diferències per al nombre d'embrions implantats (IE). A partir de la implantació fins als 18 dies de la gestació, la diferència entre femelles tractades $\mathrm{i}$ no tractades va augmentar $(-0.33,-0.70 \mathrm{i}-1.28$ per a IE, nombre de fetus vius als 12 i 18 dies de gestació ( $\mathrm{LF}_{12}$ i $\mathrm{LF}_{18}$, respectivament)). Estes diferències tenien una baixa precisió i la probabilitat de que les femelles tractades tingueren un menor nombre de fetus va ser augmentant al llarg de la gestació $(0.60,0.70$ i 0.86 per a IE, $\mathrm{LF}_{12} \mathrm{i} \mathrm{LF}_{18}$, respectivament). D'acord amb els resultats previs obtinguts per a OR i $L_{18}$, les femelles tractades van mostrar una supervivència més baixa des de l'ovulació fins als 18 dies de gestació (-0.12) i van tindre una menor supervivència embrionària (0.10) i fetal (-0.08). Les principals diferències en la supervivència fetal van aparèixer entre els dies 12 i 18 de gestació (-0.09). No obstant això, les femelles 
tractades van mostrar un pes dels fetus semblant i major pes de la placenta fetal que les femelles no tractades (0.25 grams), a més d'una menor variabilitat en estos caràcters. Estos últims resultats no estan relacionats amb un menor número d'IE o nombre de fetus vius als 18 dies de gestació. 


\section{CHAPTER ONE}

INTRODUCTION 



\subsection{RABBIT PRODUCTION}

One of the most important problems in the world is insufficient animal protein, mainly in the developing countries. Animal protein is considered as a high quality protein because it provides a sufficient amount of the essential amino acids. Continuous increase in human population needs more meat production to meet the increasing demand for animal protein. Rabbit meat is one of the recommended animal protein sources, especially in developing countries since rabbit does not compete with man for food (McNitt et al., 2013).

\subsubsection{Rabbit meat characteristics}

Rabbit meat is characterized with some advantages that make its candidacy to be a cheap source of animal protein in comparison to other meat types:

1. Rabbit meat is free to consume; no religion taboo or social stigma prohibit the consumption of this meat.

2. Economically, rabbit has superiority in converting the consumed protein into edible meat $(20 \%)$ better than pigs (15-18\%) and cattle (9-12\%), and closer to the percent achieved by broiler chickens (22-23\%), (Suttle, 2010 cited by Adeniji et al., 2015).

3. Rabbit meat is considered as a delicacy and healthy food product, easy to digest because of the highly protein content, low in calories, fat and cholesterol contents (Table 1.1). Thus, it is suitable for feeding children and old people (Zotte, 2000). Also, rabbit meat contains calcium and phosphorus with a percentage higher than other meats and it is riche in B vitamins group [B2, B3, B5 and B12] (Combes, 2004 cited by Nistor et al., 2013). Finally, rabbit meat is very tender and juicy (Szkucik and Pyz-Łukasik, 2009). 
Table 1.1. Comparative composition of rabbit, chicken, beef and pig meat (Nistor et al., 2013).

\begin{tabular}{lcccc}
\hline Ingredient & Rabbit & Chicken & Beef & Pig \\
\hline Moisture $(\mathrm{g} / 100 \mathrm{~g})$ & $68.5 \pm 1.05$ & $68.1 \pm 1.19$ & $53.2 \pm 1.21$ & $43.7 \pm 2.13$ \\
Protein $(\mathrm{g} / 100 \mathrm{~g})$ & $21.2 \pm 0.79$ & $20.1 \pm 0.27$ & $26.3 \pm 0.16$ & $27.3 \pm 0.22$ \\
Fat $(\mathrm{g} / 100 \mathrm{~g})$ & $9.2 \pm 0.38$ & $10.8 \pm 0.08$ & $19.6 \pm 0.09$ & $28.2 \pm 0.13$ \\
Ash $(\mathrm{g} / 100 \mathrm{~g})$ & $1.1 \pm 0.08$ & $1.0 \pm 0.05$ & $0.9 \pm 0.07$ & $0.8 \pm 0.11$ \\
Calcium $(\mathrm{mg} / 100 \mathrm{~g})$ & $21.4 \pm 0.09$ & $12.1 \pm 0.04$ & $10.9 \pm 0.38$ & $9.3 \pm 0.47$ \\
Phosphorus $(\mathrm{mg} / 100 \mathrm{~g})$ & $347.0 \pm 0.26$ & $252.0 \pm 0.06$ & $179.0 \pm 3.62$ & $176.4 \pm 3.36$ \\
Sodium $(\mathrm{mg} / 100 \mathrm{~g})$ & $40.5 \pm 0.89$ & $71.4 \pm 0.92$ & $63.0 \pm 0.90$ & $67.3 \pm 0.91$ \\
Cholesterol $(\mathrm{mg} / 100 \mathrm{~g})$ & $56.4 \pm 0.92$ & $68.3 \pm 2.14$ & $114.5 \pm 11.68$ & $108.4 \pm 10.31$ \\
\hline
\end{tabular}

\subsubsection{Rabbit meat production}

Rabbit production meat represents about $3.5 \%$ of the total meat production around the world. World's production of rabbit meat in 2013 reached 1.78 million tonnes (FAO-STAT, 2015), while the world's higher production has been achieved in 2007 with 1.86 million tonnes of rabbit meat (Figure 1.1).

China came in the first place for rabbit meat production all over the world and Asia with a production in 2013 of 727,000 tonnes and Venezuela came next with production of 275,000 tonnes (FAO-STAT, 2015). Egypt was ranked in the first place in Africa with a $66 \%$ of total African production of rabbit meat (54,500 tonnes in 2013). In European Union, Italy achieved the highest production (262,500 tonnes) followed by Spain (63,289 tonnes) and France (52,131 tonnes), (FAO-STAT, 2015). In Spain, the highest production Autonomous Community is Catalonia, with one-third of Spanish production (33.1\%), followed by Aragon (14.5\%), Galicia (13.8\%) and Valencian Community (9.2\%). Also, smaller amount from Castile and León, Castilla-La Mancha and Andalusia are produced (EFSA, 2005). 


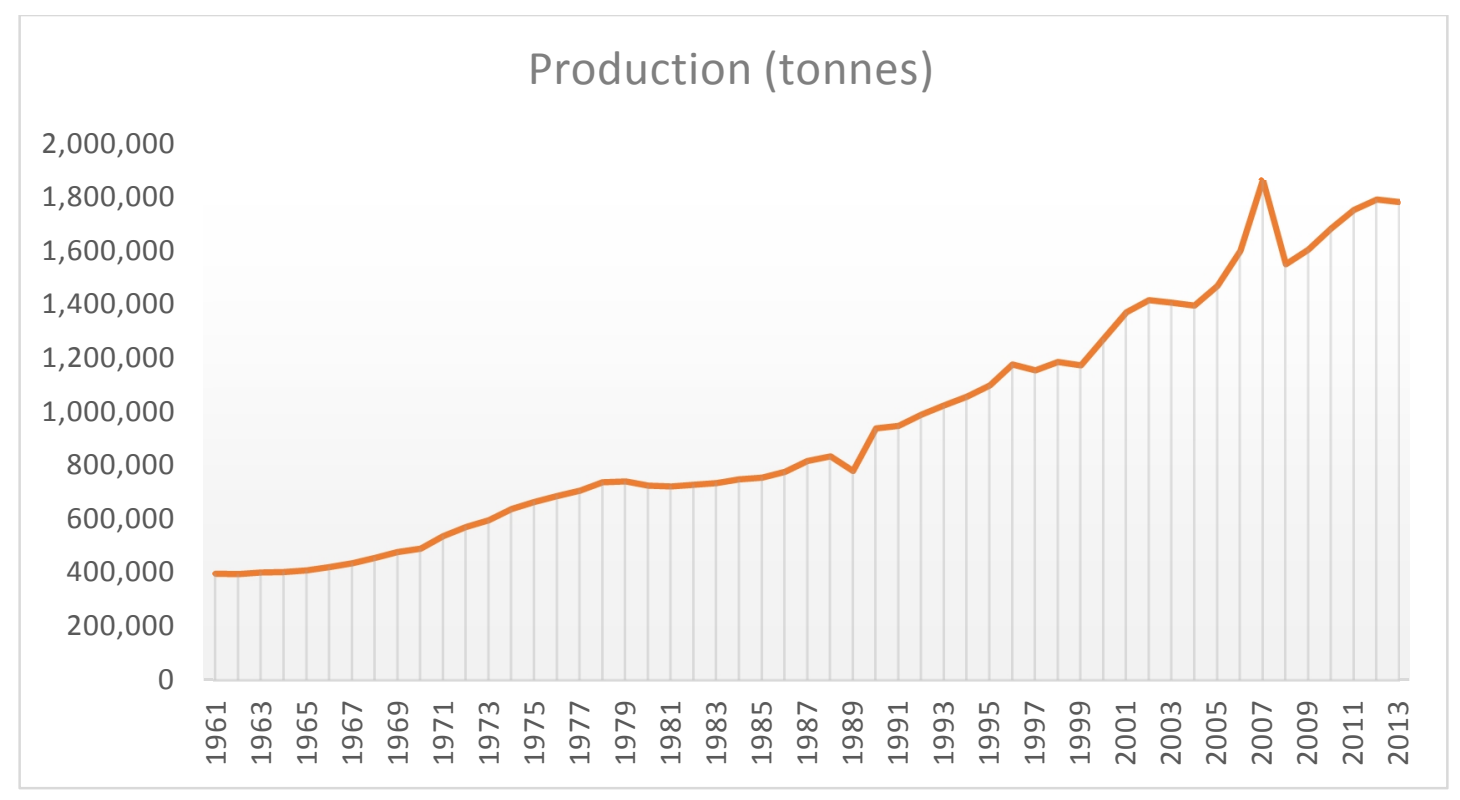

Figure 1.1. World production of rabbit meat (tonnes) from 1961 to 2013. (FAO-STAT, 2015)

\subsection{GENETIC IMPROVEMENT IN RABBITS}

The main traits in rabbit meat production are feed conversion rate and litter size (Armero and Blasco, 1992; Eady and Garreau, 2007; Cartuche et al., 2014). Improvement of feed conversion rate reduces the feeding costs, which are the main part of the variable costs of the product sold. Feed conversion rate is difficult and expensive to measure, thus correlated traits like growth rate are often used instead, but always with the objective of improving food conversion rate (Baselga and Blasco, 1989). On the other hand, an increase in litter size reduces the fixed costs because costs can be distributed among a higher number of animals (Cartuche et al., 2014). Hence, growth rate and litter size are involved in most rabbit genetic improvement programs.

Rabbit's genetic improvement programs are organized in a pyramidal structure with three levels (Figure 1.2): nucleus populations on the top of the pyramid, multipliers and commercial farms on the bottom. In most nucleus populations, selection is performed on three specialized rabbit lines, two maternal lines, selected to increase 
litter size, and a paternal line, selected for growth rate. In the multipliers, animals from both maternal lines are mated to obtain hybrids. Performing crosses between maternal lines has different benefits: (i) hybrid females present heterosis in reproductive traits, which leads to higher litter size, (ii) a reduction of the genetic material cost and (iii) a depreciation of accumulated inbreeding within the selected lines. Finally, in the commercial farms, hybrid females are mated to males from the paternal line, usually selected for growth rate, and the final product is sent to slaughterhouse. Therefore, three way crosses are usually carried out. Although maternal lines are not selected for growth traits, they should have acceptable level for growth traits because commercial progeny received $50 \%$ of their genetic material from maternal lines. Commercial rabbits exploit the complementarity of the crosses.

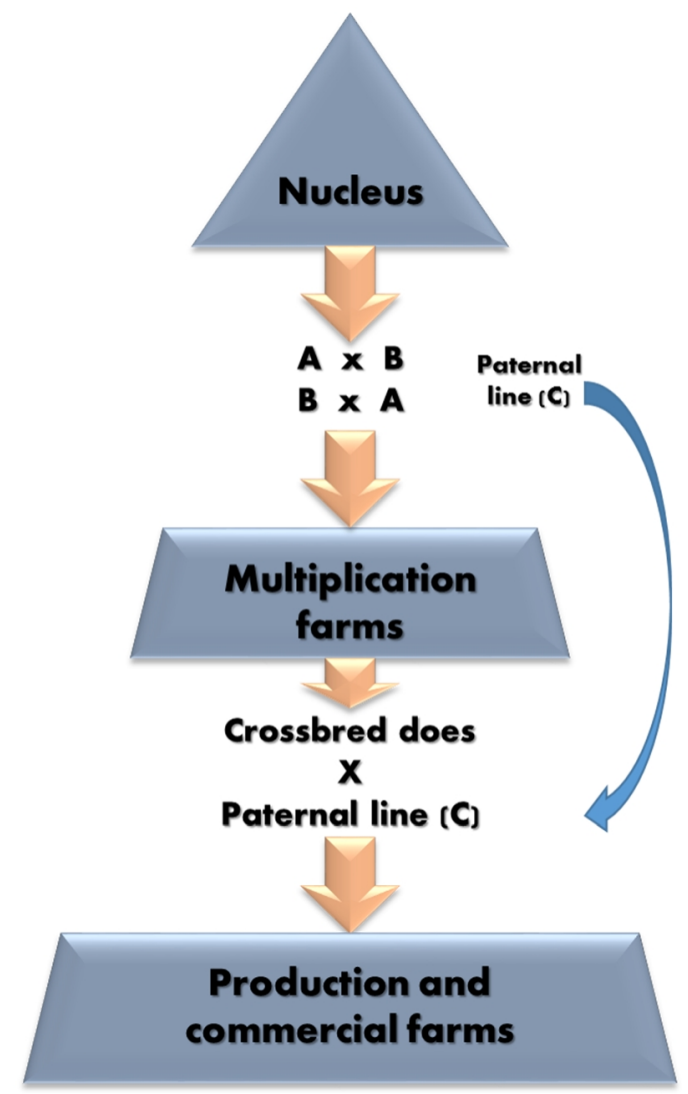

Figure 1.2. Genetic improvement process diagram, A and B are two maternal lines and $\mathrm{C}$ is a paternal one. 


\subsubsection{Selection for litter size}

Litter size in rabbits is considered as one of the most important economic components on intensive meat production (Eady and Garreau, 2007; Cartuche et al., 2014) as it was quoted in the previous section. Litter size at birth and litter size at weaning have been the two main selection criteria considered in genetic programs. Litter size at weaning is usually measured at 28 days of age. Most of the maternal lines are selected by litter size at weaning since this trait reflects both the prolificacy as well as the milking and nursing ability. Also, litter size at weaning has a positive and high genetic correlation with litter size at marketing (Nofal et al., 2008), usually measured at 63 days of age. A disadvantage in using litter size at weaning as selection criteria is its lower heritability, compared to number of kits born alive.

\subsubsection{Genetic parameters}

Nowadays, there is no doubt that the heritability of litter size is low, around 0.10 (for a review see Rochambeau, 1988 and Blasco et al., 1996; and references from 1996 in Table 1.2). Like in rabbits, estimated heritabilities for litter size at birth in pigs were low. Similar values to heritability have been estimated for the permanent environmental effect of litter size (Table 1.2). Generally, estimates of heritability tended to decrease from litter size at birth to weaning time (Table 1.2). Variation in heritability estimates could be attributed to the used line and also the bias due to the model and method of estimation and the environmental variability.

Estimated genetic correlations between litter size at different moments (birth, weaning and marketing age) are high, around 0.90, and positive (García and Baselga, 2002 a,b; Ragab and Baselga, 2011). 
Table 1.2. Heritability $\left(h^{2}\right)$ and repeatability $(r)$ estimates for litter size traits (litter size (LS, total number of kits born), number of kits born alive (NBA), number of kits at weaning (NW) and number of rabbits at marketing (NM)) in different rabbit lines.

\begin{tabular}{|c|c|c|c|c|}
\hline Trait & $h^{2}$ & $r$ & Breed/line & Reference \\
\hline \multirow[t]{13}{*}{$\mathbf{L S}$} & 0.08 & 0.15 & $\mathrm{H}$ & Cifre et al. (1998) \\
\hline & $0.10 \pm 0.01$ & 0.22 & $\mathrm{~V}$ & García and Baselga (2002a) \\
\hline & $0.15 \pm 0.02$ & 0.24 & $\mathrm{~A}$ & García and Baselga (2002b) \\
\hline & $0.14 \pm 0.02$ & - & $\mathrm{A}$ & \multirow{3}{*}{ Piles et al. (2006) } \\
\hline & $0.11 \pm 0.01$ & - & Prat & \\
\hline & $0.10 \pm 0.01$ & - & $\mathrm{V}$ & \\
\hline & $0.14 \pm 0.01$ & 0.24 & $\mathrm{~A}, \mathrm{~V}, \mathrm{H}$ and $\mathrm{LP}$ & Ragab and Baselga (2011) \\
\hline & $\begin{array}{c}0.09 \\
{[0.03,0.14]^{1}}\end{array}$ & - & OR & Laborda et al. (2011) \\
\hline & $0.09 \pm 0.10$ & $0.34 \pm 0.03$ & APRI & Abou Khadiga et al. (2012) \\
\hline & $0.13 \pm 0.02$ & - & A & \multirow{4}{*}{ Fernández (2016) } \\
\hline & $0.16 \pm 0.02$ & - & $\mathrm{V}$ & \\
\hline & $0.09 \pm 0.02$ & - & $\mathrm{H}$ & \\
\hline & $0.16 \pm 0.03$ & - & LP & \\
\hline \multirow[t]{14}{*}{ NBA } & 0.08 & 0.15 & $\mathrm{H}$ & Cifre et al. (1998) \\
\hline & $0.07 \pm 0.01$ & 0.17 & $\mathrm{~V}$ & García and Baselga (2002a) \\
\hline & $0.13 \pm 0.02$ & 0.21 & $\mathrm{~A}$ & García and Baselga (2002b) \\
\hline & $0.12 \pm 0.02$ & - & $\mathrm{A}$ & \multirow{3}{*}{ Piles et al. (2006) } \\
\hline & $0.08 \pm 0.01$ & - & Prat & \\
\hline & $0.07 \pm 0.01$ & - & $\mathrm{V}$ & \\
\hline & $0.15 \pm 0.02$ & 0.25 & $\mathrm{~V}$ & Sánchez et al. (2008) \\
\hline & $0.10 \pm 0.01$ & 0.20 & $\mathrm{~A}, \mathrm{~V}, \mathrm{H}$ and $\mathrm{LP}$ & Ragab and Baselga (2011) \\
\hline & $\begin{array}{c}0.08 \\
{[0.03,0.14]^{1}}\end{array}$ & - & OR & Laborda et al. (2011) \\
\hline & $0.12 \pm 0.01$ & $0.30 \pm 0.03$ & APRI & Abou Khadiga et al. (2012) \\
\hline & $0.11 \pm 0.02$ & - & $\mathrm{A}$ & \multirow{4}{*}{ Fernández (2016) } \\
\hline & $0.12 \pm 0.01$ & - & $\mathrm{V}$ & \\
\hline & $0.07 \pm 0.02$ & - & $\mathrm{H}$ & \\
\hline & $0.09 \pm 0.03$ & - & LP & \\
\hline
\end{tabular}

${ }^{1}$ High posterior density interval at $95 \%$.

Updated from Ragab (2012). 
Table 1.2. Continued. Heritability $\left(h^{2}\right)$ and repeatability $(r)$ estimates for litter size traits (litter size (LS, total number of kits born), number of kits born alive (NBA), number of kits at weaning (NW) and number of rabbits at marketing (NM)) in different rabbit lines.

\begin{tabular}{|c|c|c|c|c|}
\hline Trait & $h^{2}$ & $r$ & Breed/line & Reference \\
\hline \multirow[t]{13}{*}{ NW } & 0.06 & 0.12 & $\mathrm{H}$ & Cifre et al. (1998) \\
\hline & $0.05 \pm 0.01$ & 0.13 & $\mathrm{~V}$ & García and Baselga (2002a) \\
\hline & $0.11 \pm 0.02$ & 0.18 & A & García and Baselga (2002b) \\
\hline & $0.11 \pm 0.02$ & - & $\mathrm{A}$ & \multirow{3}{*}{ Piles et al. (2006) } \\
\hline & $0.06 \pm 0.01$ & - & Prat & \\
\hline & $0.04 \pm 0.01$ & - & $\mathrm{V}$ & \\
\hline & $0.08 \pm 0.01$ & 0.15 & LP & Sánchez et al. (2008) \\
\hline & $0.08 \pm 0.01$ & 0.16 & $\mathrm{~A}, \mathrm{~V}, \mathrm{H}$ and $\mathrm{LP}$ & Ragab and Baselga (2011) \\
\hline & $0.10 \pm 0.01$ & $0.27 \pm 0.04$ & APRI & Abou Khadiga et al. (2012) \\
\hline & $0.09 \pm 0.02$ & - & A & \multirow{4}{*}{ Fernández (2016) } \\
\hline & $0.09 \pm 0.01$ & - & $\mathrm{V}$ & \\
\hline & $0.04 \pm 0.02$ & - & $\mathrm{H}$ & \\
\hline & $0.08 \pm 0.02$ & - & LP & \\
\hline \multirow[t]{7}{*}{ NM } & 0.06 & 0.11 & $\mathrm{H}$ & Cifre et al. (1998) \\
\hline & 0.05 & 0.12 & V & García and Baselga (2002a) \\
\hline & $0.12 \pm 0.02$ & 0.17 & A & García and Baselga (2002b) \\
\hline & $0.08 \pm 0.01$ & 0.15 & $\mathrm{~A}, \mathrm{~V}, \mathrm{H}$ and $\mathrm{LP}$ & Ragab and Baselga (2011) \\
\hline & $0.10 \pm 0.02$ & - & $\mathrm{A}$ & \multirow{3}{*}{ Fernández (2016) } \\
\hline & $0.08 \pm 0.01$ & - & $\mathrm{V}$ & \\
\hline & $0.04 \pm 0.02$ & - & $\mathrm{H}$ & \\
\hline
\end{tabular}

Updated from Ragab (2012).

Estimated correlations between litter size and its components are scarce in the literature. Litter size seems to show low correlation with ovulation rate, ranging from 0.20 to 0.36 , with a high standard error (Blasco et al., 1993b; Laborda et al., 2011). In pigs, estimated values from 0.24 to 0.52 were also reported with a low accuracy (Johnson et al., 1999; Cunningham et al., 1979; Ruiz-Flores and Johnson, 2001). The nature of this kind of experiments, which need laparoscopies, laparotomies or slaughtering the female to measure ovulation rate and implanted embryos prevent from 
collecting a large number of data, making the estimation of accurate genetic correlations difficult (Laborda, 2011).

Litter size was positively correlated with embryo, foetal and prenatal survival. Genetic correlations of litter size with embryo and foetal survival were moderate (around 0.70 for both traits) and with prenatal survival was high (around 0.90) (Blasco et al., 1993 a,b for a review; Laborda et al., 2012a). The positive correlations between litter size and survival rates agree with the estimates found in pigs (Johnson et al., 1999 and Rosendo et al., 2007a). These results should be taken with caution due to high standard errors.

There were also very few estimates of genetic correlations between litter size and growth traits in rabbits. Studies do not show any clear pattern but generally estimated correlations are null or low, usually from -0.03 to 0.06 , and with a high standard error in maternal lines selected for litters size at weaning or at birth (Camacho and Baselga, 1990; Rochambeau, 1994; Gómez et al., 1998; García and Baselga, 2002c; Mínguez et al., 2012) and in a paternal line selected for growth rate (Garreau et al., 2000).

\subsubsection{Response to selection for litter size}

Responses estimated in closed populations were close to 0.1 rabbits per generation (Table 1.3). These results are in agreement with those found in pigs by several authors after selection for number of born alive (reviewed by Rothschild and Bidanel, 1998). In mice, higher response (from 0.15 to 0.20 kits per generation) was obtained from direct selection for litter size (Bradford, 1968, 1969; Falconer, 1971; Bakker et al., 1978; Gion et al., 1990). Recently, Nielsen et al. (2013) reported a higher response at litter size at birth in pigs ( 0.19 piglets per generation) after selection for litter size at day 5 from birth. 
Statistical methods (Mixed model methodology or Bayesian inference) and the use of a control population (unselected population or contemporary population from frozen embryos) were used to estimate the response to selection in litter size. In many cases, there was a good agreement between the responses estimated using both types of methodologies (Rochambeau et al, 1998; García and Baselga, 2002a; Tudela et al., 2003)

Table 1.3. Direct response for number of kits at weaning (NW) or number of kits born alive (NBA) estimated per generation $(\mathrm{G})$ in rabbits.

\begin{tabular}{lccccl}
\hline $\begin{array}{c}\text { Criteria of } \\
\text { selection }\end{array}$ & Direct response & G & Line & Method & Reference \\
\hline & 0.09 & $6^{\mathrm{a}}$ & V & $\begin{array}{c}\text { Cryo-CP } \\
\text { B-R }\end{array}$ & García and Baselga \\
& 0.09 & 21 & & (2002b) \\
\cline { 2 - 6 } NW & 0.09 & $9^{\mathrm{b}}$ & A & Cryo-CP & García and Baselga \\
& 0.18 & 26 & & B-R & (2002a) \\
\cline { 2 - 6 } & 0.08 & 18 & A1077 & U-CP & Rochambeau et al. \\
& 0.08 & 18 & & B-R & (1998) \\
\hline NBA & 0.13 & - & A2066 & - & Rochambeau et al. \\
& & & & & (1994) \\
\hline
\end{tabular}

${ }^{\mathrm{a}}$ The control population was the generation 15 and the selected one was the generation 21 .

${ }^{\mathrm{b}}$ The control population was the generation 17 and the selected one was the generation 26 .

Cryo- $\mathrm{CP}=$ Cryopreserved control population, $\mathrm{B}-\mathrm{R}=$ Best Linear Unbiased PredictionRestricted Maximum Likelihood, U-CP= Unselected control population.

The increase observed in litter size after numerous generations of selection was usually due to an increase in ovulation rate $(0.18$ oocytes per generation in line $\mathrm{V}$ and 0.06 oocytes per generation in line A1077; García and Baselga, 2002a and Brun et al., 1992, respectively) (Table 1.4). However, this response was likely due to a decrease in 
foetal mortality in A line, selected by an index of selection for litter size at weaning (García and Baselga, 2002b).

In pigs and mice, like in rabbits, selection for increased litter size is usually associated with an increase in the number of shed ova without or with small changes in prenatal survival (Bolet et al., 1989; Haley and Lee, 1992 in pigs; Land and Falconer, 1969; Falconer, 1963; Bakker et al., 1978; Gion et al., 1990 in mice).

Table 1.4. Correlated response on litter size (LS, total number of kits born), number of kits born alive (NBA), number of rabbits at marketing (NM), ovulation rate (OR, ova) and prenatal survival (PS) estimated per generation in rabbits after selection for litter size at weaning (NW).

\begin{tabular}{|c|c|c|c|c|c|c|c|c|c|}
\hline \multirow{2}{*}{$\begin{array}{c}\text { Criteria } \\
\text { of } \\
\text { selection }\end{array}$} & \multicolumn{5}{|c|}{ Correlated response } & \multirow{2}{*}{$\mathbf{G}$} & \multirow{2}{*}{ Line } & \multirow{2}{*}{ Method } & \multirow{2}{*}{ Reference } \\
\hline & $\mathbf{L S}$ & NBA & $\mathbf{N M}$ & OR & PS & & & & \\
\hline \multirow{3}{*}{ NW } & $0.10^{\mathrm{a}}$ & $0.10^{\mathrm{a}}$ & $0.09^{\mathrm{a}}$ & 0.18 & 0.06 & $6^{\mathrm{b}}$ & \multirow{2}{*}{ V } & Cryo-CP & García and \\
\hline & 0.11 & 0.11 & 0.09 & - & - & 21 & & B-R & Baselga (2002b) \\
\hline & 0.16 & 0.18 & 0.19 & - & - & 26 & A & B-R & $\begin{array}{c}\text { García and } \\
\text { Baselga (2002b) }\end{array}$ \\
\hline
\end{tabular}

\footnotetext{
${ }^{\mathrm{a}}$ Standard error for LS, NBA and NM were ranged from 0.003 to 0.005 .

${ }^{\mathrm{b}}$ The control population was the generation 15 and the selected one was the generation 21 . $\mathrm{G}=$ Generation, Cryo- $\mathrm{CP}=$ Cryopreserved control population, $\mathrm{B}-\mathrm{R}=$ Best Linear Unbiased Prediction-Restricted Maximum Likelihood.
}

There are doubts about magnitude and sign of correlated response on growth traits after selection for litter size. In a rabbit maternal line (V line) selected for number of kits at weaning, Rochambeau et al. (1994) reported a negative correlated response on weaning weight. In the same line, García and Baselga (2002c) found no relevant correlated response for weaning weight and growth rate during fattening period $(-0.67$ grams per generation and -0.22 grams per day and generation, respectively), and no correlated response on marketing weight (-8.00 grams per generation). The correlated 
response was estimated by comparison to a cryopreserved control population and litter size at birth was included as a covariate in the model. On the other hand, Brun and Ouhayoun (1994) observed similar weaning weight and lower adult weight in the maternal line A1077 versus its control line (-10 \pm 17 and $-124 \pm 35$ grams, respectively) after 13 generations of selection.

The low response obtained after selection for litter size in closed populations led to the search for alternative methods of selection for improving more efficiently litter size. Selection for main components of litter size, ovulation rate and prenatal survival, has been proposed as a way to improve litter size. These topics will be discussed in the next sections.

\subsubsection{Litter size components: ovulation rate and prenatal survival}

Litter size is mainly limited by two major factors: ovulation rate and prenatal survival because fertilization rate is generally high in rabbits, near $100 \%$ (Adams, 1960a; Torrès et al., 1984; Santacreu et al., 1990; Theau-Clement et al., 2009), like in pigs (Bazer et al., 1988; Soede et al., 1995; Geisert and Schmitt, 2002) and mice (Joakimsen and Baker, 1977; Wilmut et al., 1986). Thus, an approach to improve litter size is through selection for its main components, ovulation rate and prenatal survival.

\subsubsection{Ovulation rate}

\section{Ovulation process}

In rabbit does, ovulation is induced by the mating stimulus. The coitus stimulates nervously secretion of gonadotropin-releasing hormone $(\mathrm{GnRH})$ in the hypothalamus. This hormone activates the synthesis and secretion of both follicle-stimulating hormone (FSH) and the luteinizing hormone ( $\mathrm{LH})$ at the anterior pituitary gland. Folliclestimulating hormone is the most important hormone for stimulating the growth of ovarian follicle, while LH stimulates the ovulation (Rosell, 2000). A simplified diagram 
of the hormonal sequence that leads to ovulation is presented in Figure 1.3. Ovulatory follicles begin to release the oocytes at about eight hours after coitum. Most of the follicles ovulate simultaneously in a short period of time, with a small proportion of them ovulating later. Ovulation is completed at 14 hours after coitum (Fujimoto et al., 1974). The length of this process can be one of the reasons of embryonic development variation. Both, oocyte maturation degree (oocyte quality) and ovulation time are depending on the development of ovarian follicle. Also, both can affect posterior embryonic and foetal development (Bazer et al., (2014) in pig, cited by Yuan et al., 2015).

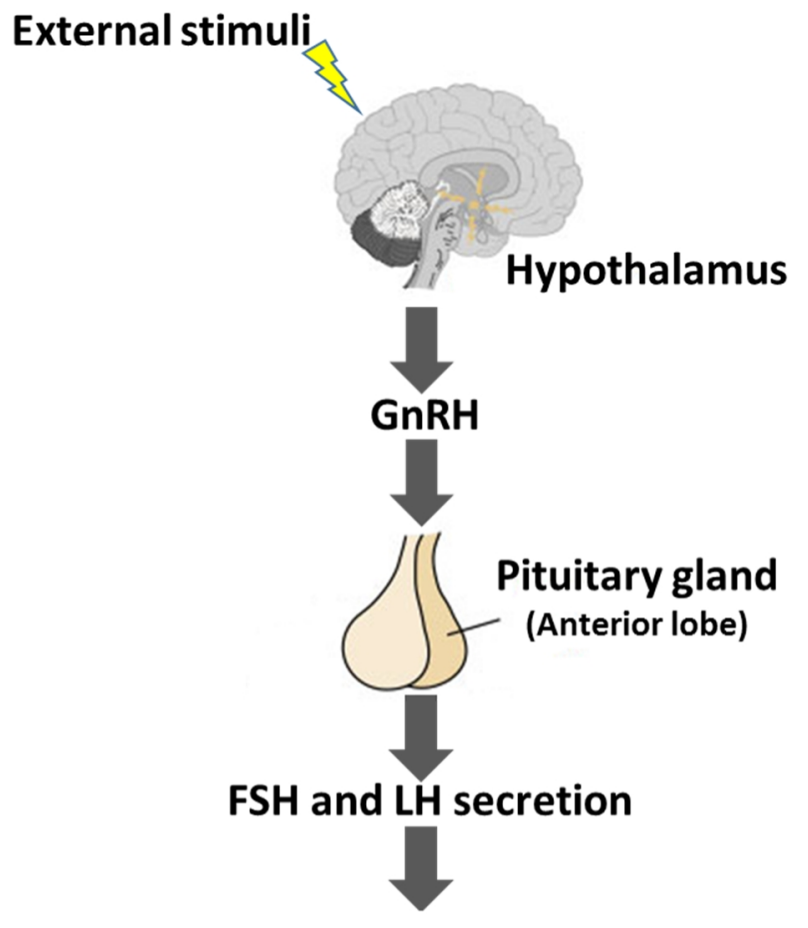

\section{Ovaries}

$\approx 10: 12 \mathrm{~h}$ after mating

\section{Ova}

Figure 1.3. Ovulation stimulation process in rabbit. 


\section{Estimation of ovulation rate}

Ovulation rate is the total number of ova shed by the ovaries at ovulation. In rabbits, ovulation rate is usually estimated as the number of corpora lutea in both ovaries, counted in vivo by laparoscopy (Figure 1.4) or post mortem after dissection of the ovary. Both procedures are very accurate techniques to measure ovulation rate (Santacreu et al., 1990).
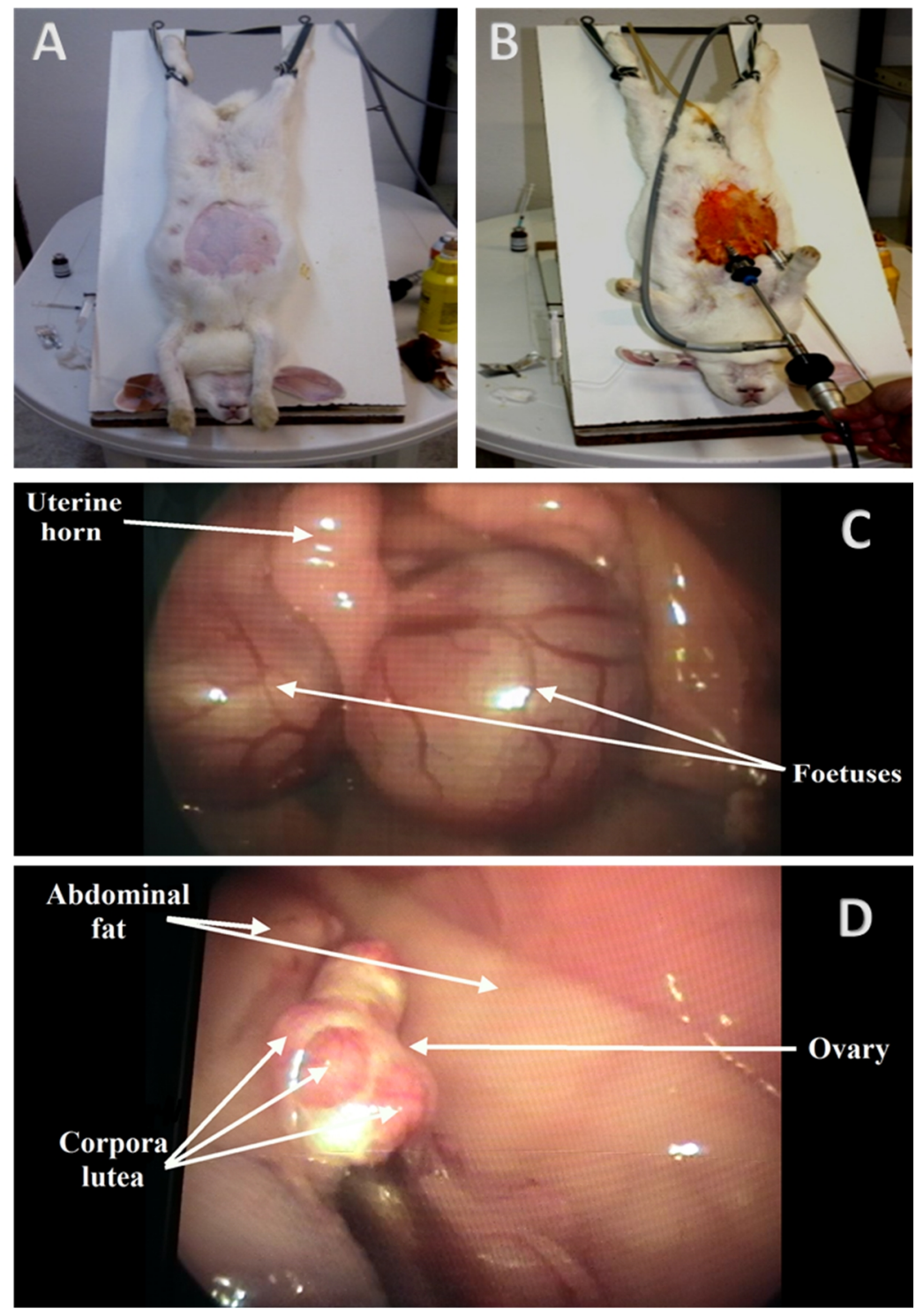

Figure 1.4. Description of the laparoscopy procedure performed at day 12 of gestation to record ovulation rate and number of implanted embryos. (A) Prepare and anesthetizing the doe. (B) Ready doe to do laparoscopy (in trendelenburg position). (C) Visualization of foetus. (D) Corpora lutea. 


\subsubsection{Prenatal survival.}

Prenatal survival is very important character in animal production because a higher prenatal survival leads to a higher litter size and consequently higher economics gains. Prenatal survival is around $70 \%$ in politocous species and it seems determined by the female (see reviews Bradford, 1979 and Blasco et al., 1993b; Mocé et al., 2004), whereas the foetus-embryo plays a secondary role. The part of prenatal survival due to the female is named uterine capacity when the uterus is overcrowded.

Prenatal survival may be divided in: pre-implantation survival (embryo survival) and post-implantation survival (foetal survival). The first one is the period from fertilization until implantation (embryonic period), and the second one is the period from implantation until birth (foetal period). Knowledge of the phenomena more important which take place during the embryonic and foetal development and also the mortality distribution along all the gestation is necessary in order to know the key moments in the determination of prenatal survival.

\section{Embryonic and foetal development}

\section{- First stages of development until implantation}

In rabbits, first embryo cleavages are observed 21-48 hours after coitus, and eight cell stage is reached 30-48 hours after coitus. Compacted morulae and blastocysts are observed 64-70 and 72-75 hours after coitus, respectively. In the blastocysts may be distinguished the inner cell mass or embryoblast and the trophoblast. The embryoblast will form the embryo and the trophoblast will form the extra-embryonic membranes, which will contribute to the placenta formation. During the first days of gestation, the covers that surround the embryo suffer important modifications (Hill, 2016).

Embryos are located in the oviducts until 66 hours after coitus, whereas 72 hours after coitus around $50 \%$ of the embryos are located into the uterus. Implantation has 
not still begun on day 6 of gestation, and the embryos are free in the uterus. Implantation begins on day 7 of gestation, and the trophoblast cells start to adhere to the epithelium of the uterus. The chronological succession of the most important phenomena observed from fertilization to implantation is showed in Table 1.5.

Table 1.5. Chronology of the major events observed from fertilization until implantation in rabbit.

\begin{tabular}{ll}
\hline Incident & Time post-coital \\
\hline Coitus and release of GnRH (hypothalamus) & 0 hour \\
Peak of LH and FSH (pituitary) & $20-120$ minutes \\
Ovulation (ovary) & $10-12$ hours \\
Fertilization & $14-18$ hours \\
Two cells & $21-28$ hours \\
Four cells & $25-32$ hours \\
Eight cells & $30-48$ hours \\
Compact morula (uterus) & $64-74$ hours \\
Blastulation & $75-96$ hours \\
Gastrulation & $120-168$ hours \\
Implantation & 7 days \\
\hline
\end{tabular}

Modified from Mocé (2003). From: Harper, 1961; Thibault, 1975; García Ximénez, 1991; López Bejar, 1995; Spies et al., 1997.

\section{- Placentation and late stages of gestation}

Placenta is formed by apposition or fusion of foetal membranes to the uterine mucosa. The primary role of placenta is to transport nutrients, respiratory gases and wastes between the maternal and foetal systems. Foetuses have four extraembryonic membranes: amnion, chorion, yolk sac and allantois.

Rabbit develop two kinds of placentas: an inverted yolk sac placentation at first and a chorioallantoic placenta. The yolk sac placentation regresses around 10 days of gestation in rabbits and serves as the primary placental organ prior to establishment of 
the chorioallantoic placenta. Chorioallantoic placenta begins its development at implantation time and finishes it around 12 day of gestation (Amoros 1952 cited by Adams 1960b). Little is known about the mechanism used by the yolk sac to nourish the foetus, but it is believed that, as equal as in mouse, it takes nutrients from uterine cavity and transfers them to the embryo through the viteline circulation (Foote and Carney, 2000). This type of nutrition is known as histiotrophic nutrition. The chorioallantoic placenta shows a different type of nutrition i.e. haemotrophic nutrition and the chorioallantoide placenta absorbs the nutrients directly from the maternal sanguineous circulation and passes them to the embryo (reviewed by Leiser and Kaufmann, 1994). In addition, important vasculature changes are observed as placentation occurs. For example, maternal blood vessels are bordered by trophoblast cells and form the lacunae typical of hemochorial placentation.
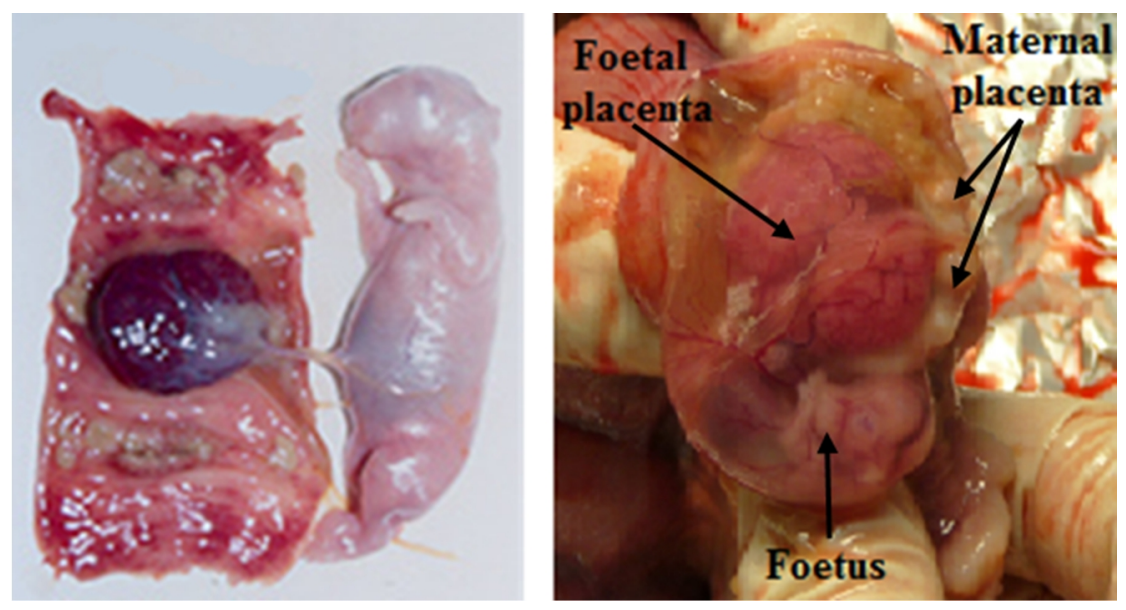

Figure 1.5. Picture of rabbit foetus and its placenta near term. From Mocé (2003) and Soriano (2014).

Chorioallantoic placenta in rabbits can be divided in two placental components, the foetal placenta (allantois portion) and the maternal placenta (chorion portion and decidua) (Figure 1.5). Both components are tightly fused but as gestation progresses it 
is easier dissected them. Foetal placental weight increases throughout gestation (1.00 gram versus 4.50 grams at 16 and 28 day of gestation, respectively) whereas maternal placental weight seems to remain constant (around 0.15 grams at 20 and 28 days of gestation; Bruce and Abdul-Karim, 1973). Moreover, it has been observed that blood flow to placenta increases as gestation progresses (Bruce and Abdul-Karim, 1973).

The final phase of the elongation of the uterus takes place in the period between days 18 and 23 of gestation. The last period of gestation is characterized by rapid growth of foetuses. This period coincides with the final phase of uterine elongation; in this moment, the tension supported by placental membranes, foetal fluids and foetus is maximum. Around day 30 of gestation, parturition is initiated by the foetuses with a complex cascade of biochemical and endocrine signals as a result of the stress caused by rapid foetal growth and the inability of the placenta to provide sufficient substrates for foetal metabolism (First and Bosc, 1979, cited by Alvariño, 1993).

\section{- Causes and distribution of prenatal mortality}

The study of mortality distribution along the gestation allows knowing the key moments in the determination of prenatal survival. Prenatal mortality in rabbits is about 30 \% (Adams, 1960b; Santacreu, 1992; Santacreu et al., 2000; García, 2001) (Figure 1.6).

Embryonic mortality varies among 10 and $14 \%$ (Adams, 1960a, 1960b; Santacreu, 1992; Santacreu et al., 2000; García, 2001) whereas foetal mortality varies among 20 and 22 \% (Adams, 1960b; Santacreu, 1992; Santacreu et al., 2000; García, 2001). Adams (1960b) observed two mortality peaks inside the post-implantation period. The first peak is located between the day 8 and 17 of gestation and it supposes the $66 \%$ of the global post-implantation mortality. During this period, a key point for foetal mortality is when the chorioallantoic placenta has finished its development and 
the nutrition begins to be controlled by the placenta around day 12 of gestation. Between day 17 and 23 of gestation, a second mortality peak takes place, and in this period the $27 \%$ of the global post-implantation mortality is produced. From day 24 until birth, very few losses are observed (Adams, 1960b).

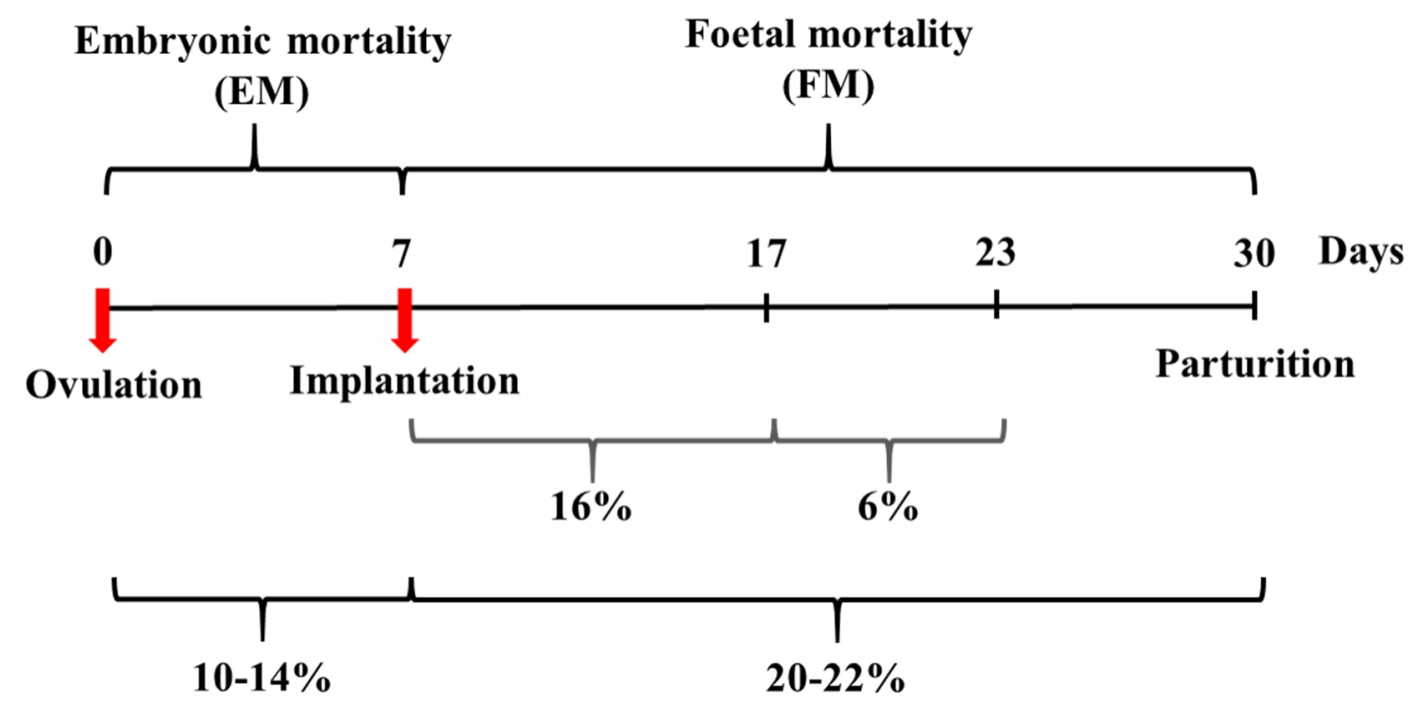

Figure 1.6. Percentage of embryonic mortality (EM) and foetal mortality (FM) in rabbits during gestation. Implantation occurs at day seven of gestation. Modified from Mocé (2003).

Some of the factors that contributed to prenatal mortality through gestation in rabbits and other prolific species are:

- Ovulation of immature oocyte (Torres, 1982 in rabbit, Koenig et al., 1986 in pigs)

- Variability of embryo development leading to an asynchrony between the embryo development and the maternal uterine environment (Torres et al., 1984 in rabbits; Pope, 1988 and Xie et al., 1990 in pigs; Wilmut et al., 1986 and Al-Shorepy et al., 1992 in mice). 
- Hormone levels and protein patterns of uterine and oviductal secretion no adequate (Beier, 2000 and Daniel, 2000 in rabbit; Bagchi et al., 2001 in humans and rats; Vallet et al., 1998 in pigs).

- Uterine overcrowding. Competition for the availability of space and nutrients among foetuses can increase embryo or/and foetal mortality (Adams, 1960b, Hafez, 1969, Argente et al., 2003 in rabbit).

\section{Estimation of prenatal survival}

Prenatal survival is calculated as the proportion of kits born from the number of corpora lutea. Besides, embryonic survival is calculated as the proportion of implanted embryos from the number of corpora lutea and foetal survival is calculated as the proportion of kits born from the number of implanted embryos.

Similar to ovulation rate, the number of implanted embryos can be counted in rabbits in vivo by laparoscopy with high accuracy (Santacreu et al., 1990), or post mortem. The laparoscopic method permits the estimation of embryonic and foetal survival in the same female, without affecting litter size. Unlike rabbits, implantation sites cannot be counted by the examination of uterine external surface using laparoscopy in pigs. All these facts support the use of rabbit as an animal experimental model to investigate the relationship between litter size and its components in the same female.

\subsubsection{Selection for ovulation rate}

The aim of selection for ovulation rate is to enhance litter size (Laborda et al., 2011). The possibility of improving litter size through the selection for ovulation rate depends on its genetic parameters. Moderate heritability of ovulation rate and its positive correlation with litter size supported the suggestion to improve litter size indirectly by selection for ovulation rate (reviewed by Blasco et al., 1993b). Besides, a 
correlated response on ovulation rate was found in lines selected by litter size (Brun et al., 1992; García and Baselga, 2002a in rabbits; Bolet et al., 1989 in pigs; Bakker et al., 1978; Gion et al., 1990 in mice).

\section{Genetic parameters}

Heritability values for ovulation rate ranged from 0.16 to 0.24 in rabbits (Table 1.6). Higher heritability for ovulation rate was estimated in pigs and mice.

Table 1.6. Heritability $\left(h^{2}\right)$ estimates for ovulation rate in different species.

\begin{tabular}{lcl}
\hline Species & \multicolumn{1}{c}{$\boldsymbol{h}^{\mathbf{2}}$} & Reference \\
\hline Rabbit & $0.21 \pm 0.11$ & Blasco et al. (1993a) \\
$0.24 \pm 0.04$ & Bolet et al. (1994) \\
& $0.16[0.07,0.25]^{1}$ & Laborda et al. (2011) \\
\hline Pig & $0.42 \pm 0.06$ & Cunningham et al. (1979) \\
& $0.17 \pm 0.08$ & Neal et al. (1989) \\
& $0.21 \pm 0.12$ & Bolet et al. (1989) \\
$0.27 \pm 0.02$ & Bidanel et al. (1996) \\
& 0.24 & Johnson et al. (1999) \\
& $0.42 \pm 0.06$ & Ruiz-Flores and Johnson (2001) \\
& 0.34 & Rosendo et al. (2007a) \\
\hline Mice & 0.31 & Land and Falconer (1969) \\
& 0.10 & Bradford (1969) \\
& $0.18 \pm 0.07$ & Long et al. (1991)
\end{tabular}

${ }^{1}$ High posterior density interval at $95 \%$.

Genetic correlations between ovulation rate and other reproductive traits are summarized in Table 1.7. As it was commented before, ovulation rate showed a low correlation with litter size in rabbits. Moreover, ovulation rate was negatively correlated with foetal and prenatal survival. Genetic correlations were low with prenatal survival and moderate with foetal survival (Table 1.7). The negative correlations between 
ovulation and survival rates agree with no correlated response on litter size and the decrease of foetal survival when selection for ovulation rate was performed.

Estimated genetic correlations between ovulation rate and growth traits from the unique experiment of selection for ovulation rate in rabbit were low and positive, 0.11 and 0.23 for weaning and marketing weight respectively, estimated with very low accuracy (Quirino et al., 2009).

Table 1.7. Genetic correlation $\left(r_{g}\right)$ estimates between ovulation rate and other litter size components in different species.

\begin{tabular}{llll}
\hline Species & Traits & \multicolumn{1}{c}{$\boldsymbol{r}_{g}$} & \multicolumn{1}{c}{ Reference } \\
\hline Rabbits & OR, LS & $-0.20[-0.77,0.30]^{1}$ & Laborda et al. (2011) \\
& OR, NBA & $-0.29[-0.99,0.18]^{1}$ & \\
\cline { 2 - 4 } & OR, IE & $0.58[0.16,0.93]^{1}$ & \\
& OR, ES & $0.02[-0.57,0.64]^{1}$ & Laborda et al. (2012a) \\
\hline OR, FS & $-0.58[-1.00,-0.26]^{1}$ & \\
\cline { 2 - 4 } & OR, PS & $-0.30 \pm 0.05$ & Blasco et al. (1993a) \\
& OR, ES & $-0.11 \pm 0.15$ & Laborda et al. (2012a) \\
\hline & & $-0.56 \pm 0.24$ & Bidanel et al. (1996) \\
& & -0.86 & Neal et al. (1989) \\
& OR, PL & 0.83 & Rohnson et al. (1999) \\
\cline { 2 - 4 } & OR, PS & -0.26 & Rosendo et al. (2007a) \\
\hline
\end{tabular}

\footnotetext{
${ }^{1}$ High posterior density interval at $95 \%$.

$\mathrm{LS}=$ Litter size, $\mathrm{OR}=$ Ovulation rate, $\mathrm{NBA}=$ Number of kits born alive, $\mathrm{IE}=$ Number of implanted embryos, ES= Embryo survival, $\mathrm{FS}=$ Foetal survival, $\mathrm{PS}=$ Prenatal survival, $\mathrm{PL}=$ Prenatal loss.
} 


\section{Response to selection}

Few experiments of selection for ovulation rate were performed in polytocous species. Only one selection experiment for ovulation rate has been carried out in rabbits (Laborda et al., 2011, 2012 a,b), three experiments in pigs (Cunningham et al., 1979; Leymaster and Christenson, 2000; Rosendo et al., 2007a) and two in mice (Bradford, 1969 and Land and Falconer, 1969).

In rabbit selection experiment, ovulation rate increased, almost $1 \%$ per generation, but no correlated response on litter size was found after ten generations of selection (Table 1.8) (Laborda et al., 2011 and Laborda et al., 2012b). Similar results were obtained after selection for ovulation rate in pigs (Johnson et al., 1984; Rosendo et al., 2007a) and mice (Bradford, 1969; Land and Falconer, 1969). The lacking of correlated response observed on litter size was mainly due to the increase of foetal mortality, around $1 \%$ per generation (Laborda et al., 2012 a,b; Table 1.8). Embryonic mortality was not modified. Studies are needed to explain the mechanism that has caused an increased foetal mortality in rabbits selected for high ovulation rate.

On the other hand, no correlated responses on growth traits were found after ten generations of selection for ovulation rate (Quirino et al., 2009). In pigs, Young et al. (1974) and Rosendo et al. (2007b) also reported no correlated response on both weaning weight and daily gain.

\section{High ovulation rate and prenatal mortality}

Some of the factors that could increase embryonic or foetal mortality in females with high ovulation rate have been quoted before: a higher proportion of immature oocytes, a greater variability in embryonic development and a higher embryonic or foetal competence for resources (reviewed by Santacreu, 2006 in rabbits; Geisert and Schmitt, 2002 in pigs). 
Similar to superovulated females, which release oocytes that are less competent (reviewed by Krisher, 2004), females with extremely high ovulation rates could ovulate immature oocytes, which may not be fertilized or may lead to poor-quality embryos that may die either before or after implantation. For example, in one of the experiments of selection for high ovulation rate in pigs, Koenig et al. (1986) found a higher proportion of oocytes classified as immature based on a chromosomal analysis in the selected females compared to unselected females, and in superovulated females compared to naturally ovulated ones; they suggested that immaturity of ova may account for a substantial proportion of prenatal mortality in gilts with high ovulation rate achieved by direct selection or through hormonal treatment.

On the other hand, Laborda et al. (2012a) suggested that the ovulatory process could take longer than usual in females with high ovulation rate. A long ovulatory duration could lead to an increased variability in embryonic development (Torres et al., 1984). In rabbits, pigs and mice, it was observed that the uterine environment was synchronic with the more developed embryos, which had a better chance to survive (Torres et al., 1984 in rabbits; Pope, 1988 and Xie et al., 1990 in pigs; Wilmut et al., 1986 and Al-Shorepy et al., 1992 in mice). Lesser developed embryos have been related to a lower embryonic and foetal survival in rabbits (Mocé et al., 2004 and Peiró et al., 2007).

In addition to the mortality associated to a reduced oocyte quality and an increased variability in embryo development, in rabbit females with extremely high ovulation rate, uterine overcrowding could reduce litter size. In females with extremely high ovulation rate and overcrowded uterine horns, the blood flow to each foetus could be reduced, decreasing their survival. The vascular supply to the foetus is especially important in rabbits due to their hemochorial placenta, an invasive placenta where foetal 
tissues directly contact the maternal blood supply (reviewed by Leiser and Kaufmann, 1994). Argente et al. (2003) observed that each additional implanted embryo implied a decrease in the blood flow that reached each foetus, reducing foetal and placental weight and increasing their probability to die.

Table 1.8. Direct response per generation in ovulation rate (OR, ova) and correlated response on litter size (LS, total number of kits born), number of kits born alive (NBA), number of implanted embryos (IE), prenatal survival (PS) and foetal survival (FS) estimated per generation in rabbits, pigs and mice.

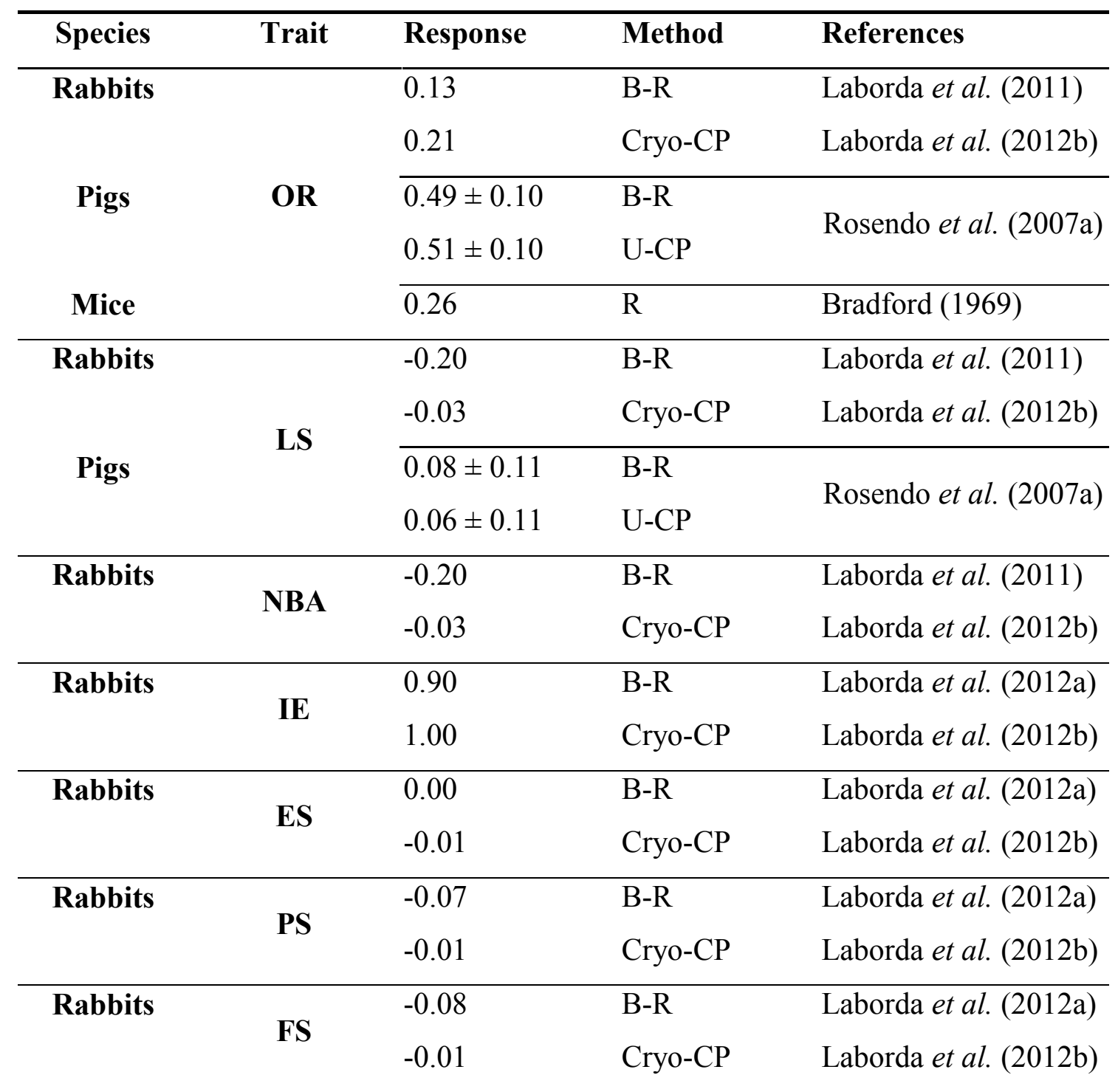

$\mathrm{B}-\mathrm{R}=$ Best Linear Unbiased Prediction-Restricted Maximum Likelihood, Cryo-CP= Cryopreserved control population, $\mathrm{U}-\mathrm{CP}=$ Unselected control population, $\mathrm{R}=$ Response estimated as a regression of generation mean on generation number. 


\subsubsection{Selection for uterine capacity}

Prenatal survival could be a good candidate to improve litter size more efficiently in rabbits (Blasco et al., 1993a). Selection for increase uterine capacity was proposed as a mean to change prenatal survival (Bennett and Leymaster, 1989).

Uterine capacity was defined by Christenson et al. (1987) as the maximum number of foetuses that a female is able to support at birth when ovulation rate is not a limiting factor. In rabbits, Blasco et al. (1994) proposed using unilateral ovariectomy to measure uterine capacity. Removing one ovary produces a duplication on average of the ovulation rate in the remaining ovary, leading to an overcrowding of embryos in the adjacent uterine horn. In female rabbit, the two uterine horns have separate cervical canals and transmigration of embryos cannot take place by way of the cervix (Fleming et al., 1984).

Two divergent selection experiments for uterine capacity were performed in rabbits, but the criterion of selection in both experiments was different. In the first experiment, selection was performed on number of dead foetuses from implantation to birth. After four generations of selection it was observed that the number of dead foetuses did not change and no significant response was obtained in litter size and its components (Bolet et al., 1994). In the second experiment, selection was made on litter size in unilateral ovariectomized females, which includes both embryo and foetal survival (Argente et al., 1997). Selection for uterine capacity through 10 generations was successful, although it does not seem to be more effective than direct selection for litter size. Similar results were obtained in pigs (Leymaster and Christenson, 2000; Gion et al., 1990) and mice (Kirby and Nielsen, 1993). Direct response on uterine capacity and correlated response on litter size and ovulation rate are represented in Table 1.9. 
Analyses based on genetic trends showed that divergence in uterine capacity between lines was 1.5 kits born after 10 generations (Blasco et al., 2005). Response was asymmetric; no differences on uterine capacity were found between the high and a cryopreserved control lines, whereas the low line and the control line differed by 1.08 kits (Mocé et al., 2005). The correlated response on litter size was also asymmetric and divergence between both lines was 2.35 kits. The low uterine capacity line had 1.88 kits less than the control line, while the high uterine capacity line differed with the control line in 0.5 kits (Santacreu et al., 2005). The correlated response on litter size in the low line was associated with a lower prenatal survival (difference between low and control lines around $7 \%$ ) and lower embryo survival. The major part of the embryonic mortality was produced before 72 hours of gestation. Moreover, embryos from the low line had a less advanced stage of development at 72 hours of gestation than embryos from the high line (Mocé et al., 2004).

Low estimated response found on uterine capacity was in agreement with low estimated heritability, around 0.10 like litter size (Bolet et al., 1994, Blasco et al., 2005, in rabbits; Kirby and Nielsen, 1993 in mice). 


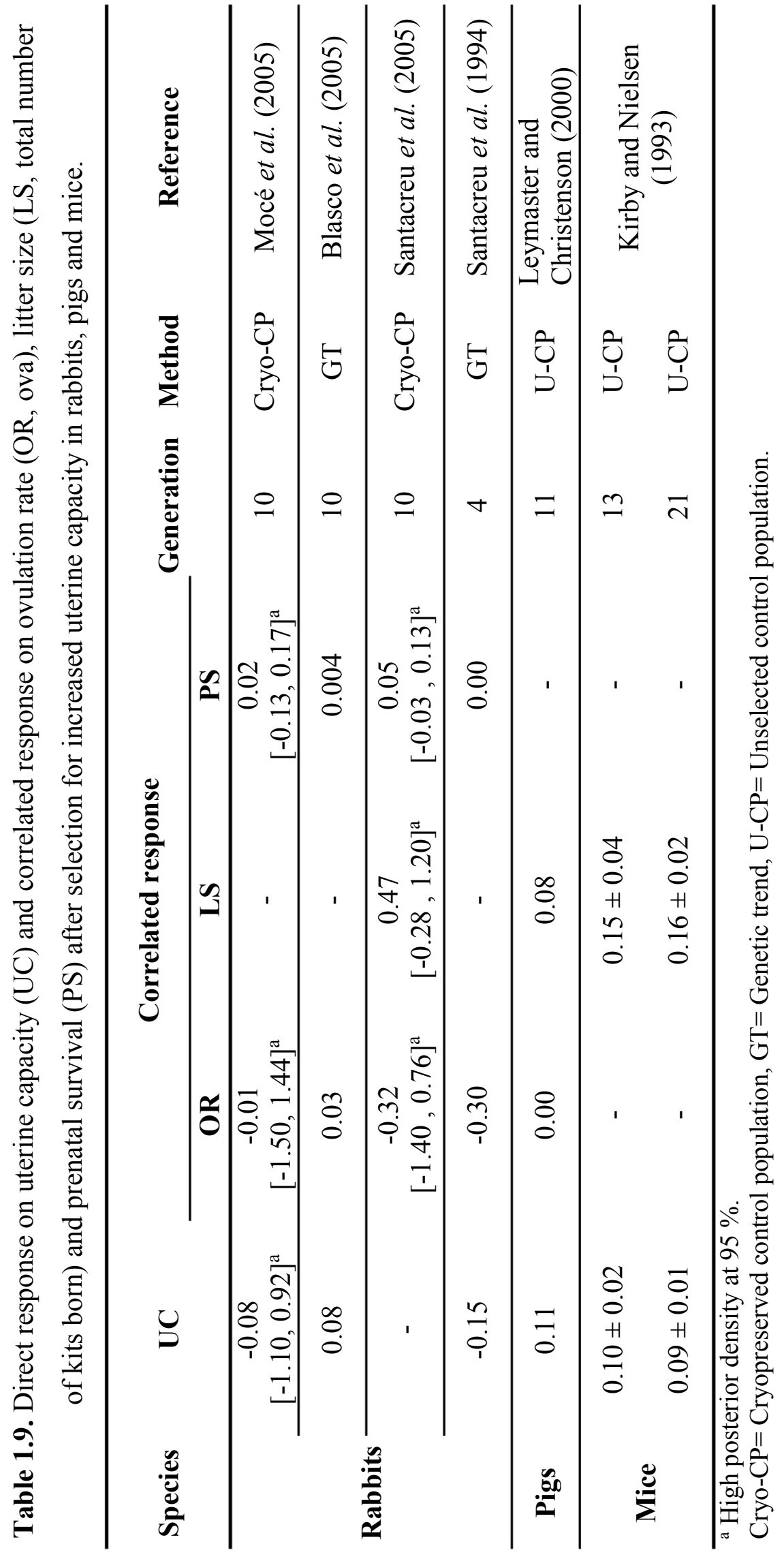




\subsubsection{Selection for ovulation rate and litter size}

Several authors predicted greater response on litter size from selection for an index of its components, ovulation rate and prenatal survival, than from direct selection for litter size in rabbits (Blasco et al., 1993b), pigs (Johnson et al., 1984; Bennett and Leymaster, 1989) and mice (Clutter et al., 1990; Ribeiro et al., 1997 a,b). Two experiments of index selection were performed in prolific species (Clutter et al., 1990 in mice; Johnson et al., 1999 in pigs). In these experiments, response on litter size was lower than expected. An alternative to an index to improve litter size could be independent culling levels (two-stage) selection to avoid the sensitivity of selection index to the genetic correlation estimated with low accuracy. In pigs, a two-stage experiment was successful to improve litter size (Ruíz-Flores and Johnson, 2001).

Ruiz-Flores and Johnson (2001) performed a two-stage selection by ovulation rate and litter size in pigs in a line selected previously for a selection index included ovulation rate and embryo survival for eight generations. Firstly, females born in $50 \%$ of highest litters in number of piglets were selected. In the second stage, $50 \%$ of these previously selected females were selected on their ovulation rate measured by laparotomy after 10 days of their second oestrus. Estimated responses after eight generations of selection were $0.33 \pm 0.06$ pigs and $0.26 \pm 0.07$ ova per generation for both litter size and ovulation rate, respectively. Also, an increase of $7.87 \%$ in prenatal survival was observed.

Effectiveness of the two-stage selection in pigs encouraged performing the same experiment in rabbits. The first experiment of two-stage selection for ovulation rate and litter size in rabbits has been performed in Universitat Politècnica de València. This $\mathrm{PhD}$ focuses on the study of genetic response after 11 generations of selection by 
independent culling levels for ovulation rate and litter size in a line previously selected for ovulation rate during six generations.

\subsection{REFERENCES}

Abou Khadiga, G., Y. M. K. Youssef and M. Baselga (2012). Characterization of reproductive performance of the APRI line of rabbits. In: Proceeding $10^{\text {th }}$ World Rabbit Congress, Sharm El- Sheikh, Egypt. Volume 1: 743-747.

Adams, C. E. (1960a). Prenatal mortality in the rabbit Oryctolagus cuniculus. Journal of Reproduction and Fertility, 1: 36-44.

Adams, C. E. (1960b). Studies on prenatal mortality in the rabbit, Oryctolagus cuniculus: the amount and distribution of loss before and after implantation. Journal of Endocrinology, 19: 325-344.

Adeniji, A. A., S. Rumak and R. A. Oluwafemi (2015). Effects of replacing groundnut cake with rumen content supplemented with or without enzyme in the diet of weaner rabbits. Lipids in Health and Disease, 1: 1-6.

Al-Shorepy, S. A., A. C. Clutter, R. M. Blair and M. K. Nielsen (1992). Effects of three methods of selection for litter size in mice on preimplantation embryonic development. Biology of Reproduction, 46: 958-963.

Alvariño, J. M. R. (1993). Control de la reproducción en el conejo. Mundi-prensa libros, Madrid, Spain.

Amoroso, E. C. (1952). Placentation. In: Marshall's physiology of reproduction. Longman, London, United Kingdom. Pages: 127-311. 
Argente M. J., M. A. Santacreu, A. Climent and A. Blasco (2003). Relationships between uterine and fetal traits in rabbits selected on uterine capacity. Journal of Animal Science, 81: 1265-1273.

Argente, M. J., M. A. Santacreu, A. Climent, G. Bolet and A. Blasco (1997). Divergent selection for uterine capacity in rabbits. Journal of Animal Science, 75: 23502354.

Armero, Q. and A. Blasco (1992). Economic weights for rabbit selection indices. Journal of Applied Rabbit Research, 15: 637-642.

Bagchi, I. C., Q. Li and Y. P. Cheon (2001). Role of steroid hormone-regulated genes in implantation. Annals of the New York Academy of Sciences, 943: 68-76.

Bakker, H., J. H. Wallinga and R. D. Politiek (1978). Reproduction and body weight of mice after long-term selection for large litter size. Journal of Animal Science, 46: $1572-1580$

Baselga, M. and A. Blasco (1989). Mejora Genética del Conejo de producción de carne. Mundi-prensa libros, Madrid, Spain.

Bazer, F. W., G. Wu, G. A. Johnson and X. Wang (2014). Environmental factors affecting pregnancy: endocrine disrupters, nutrients and metabolic pathways. Molecular and Cellular Endocrinology, 398: 53-68.

Bazer, F. W., W. W. Thatcher, F. Martinat-Botte and M. Terqui (1988). Conceptus development in Large White and prolific Chinese Meishan pigs. Journal of Reproduction and Fertility, 84: 37-42.

Beier, H. M. (2000). The discovery of uteroglobin and its significance for reproductive biology and endocrinology. Annals of the New York Academy of Sciences, 923: 9-24. 
Bennett, G. L., and K. A. Leymaster (1989). Integration of ovulation rate, potential embryonic viability and uterine capacity into a model of litter size in swine. Journal of Animal Science, 67: 1230-1241.

Bidanel, J. P., J. Gruand and J. Legault (1996). Genetic variability of age and weight at puberty, ovulation rate and embryo survival in gilts and relations with production traits. Genetics Selection Evolution, 28: 103-117.

Blasco, A., J. A. Ortega, M. A. Santacreu and A. Climent (2005). Divergent selection for uterine capacity in rabbits. I. Genetic parameters and response to selection. Journal of Animal Science, 83: 2297-2302.

Blasco, A., J. P. Bidanel, G. Bolet, C. Haley and M. A. Santacreu (1993b). The genetics of prenatal survival of pigs and rabbits: A review. Livestock Production Science, 37: $1-21$.

Blasco, A., M. A. Santacreu, R. Thompson and C. S. Haley (1993a). Estimates of genetic parameters for ovulation rate, prenatal survival and litter size in rabbits from an elliptical experiment. Livestock Production Science, 34: 163-174.

Blasco, A., P. Dando, J. Gogue and J. P. Bidanel (1996). Relationships between ovulation rate, prenatal survival and litter size in French Large White Pigs. Journal of Animal Science, 63: 143-148.

Blasco, A., M. J. Argente, C. Haley and M. A. Santacreu (1994). Relationships between components of litter size in unilaterally ovariectomized and intact rabbit does. Journal of Animal Science, 72: 3066-3072.

Bolet, G., L. Ollivier and P. Dando (1989). Sélection sur la prolificité chez le porc. I. Résultats d'une expérience de sélection sur onze générations. Genetics Selection Evolution, 21: 93-106. 
Bolet, G., M. A. Santacreu, M. J. Argente, A. Climent and A. Blasco (1994). Divergent selection for uterine efficiency in unilaterally ovariectomized rabbits. I. Phenotypic and genetic parameters. In: Proceeding $5^{\text {th }}$ World Congress on Genetics Applied to Livestock Production, Guelph, Canada. Volume 19: 261-264.

Bradford, G. E. (1968). Selection for litter size in mice in the presence and absence of gonadotropin treatment. Genetics, 58: 283-295.

Bradford, G. E. (1969). Genetic control of ovulation rate and embryo survival in mice. I. Response to selection. Genetics 61: 907-918.

Bradford, G. E. (1979). Genetic variation in prenatal survival and litter size. Journal of Animal Science, 49: 66-74.

Bruce, N. W. and R. W. Abdul-Karim (1973). Relationships between fetal weight, placental weight and maternal placental circulation in the rabbit at different stages of gestation. Journal of Reproduction and Fertility, 32: 15-24.

Brun J. M. and J. Ouhayoun (1994). Qualités bouchères de lapereaux issus d'un croisement diallèle de 3 souches: interaction du type génétique et de la taille de portée d'origine. Annales de Zootechnie, 43: 173-183.

Brun, J. M., G. Bolet and J. Ouhayoun (1992). The effects of crossbreeding and selection on productive and reproductive traits in a triallel experiment between three strains of rabbits. Journal of Applied Rabbit Research, 15: 181-189.

Camacho, J. and M. Baselga (1990). Genetic correlation between reproductive and growth traits in rabbits. In: Proceeding $4^{\text {th }}$ World Congress on Genetic Applied Livestock Production, Edinburgh, Scotland. Volume 16: 366-369. 
Cartuche, L., M. Pascual, E. A. Gómez and A. Blasco (2014). Economic weights in rabbit meat production. World Rabbit Science, 22: 165-177.

Christenson, R. K., K. A. Leymaster and L. D. Young (1987). Justification of unilateral hysterectomy-ovariectomy as a model to evaluate uterine capacity in swine. Journal of Animal Science, 65: 738-744.

Cifre, J., M. Baselga, F. Garcia-Ximenez and J. S. Vicente (1998). Performance of hyperprolific rabbit line. I. Litter size traits. Journal of Animal Breeding and Genetics, 115: 131-138.

Clutter, A. C., M. K. Nielsen and R. K. Johnson (1990). Alternative methods of selection for litter size in mice: Characterization of base population and development of methods. Journal of Animal Science, 68: 3536-3542.

Combes, S. (2004). Valeur nutritionnelle de la viande de lapin. INRA Productions Animales, 17: 373-383.

Cunningham, P. J., M. E. England, L. D. Young and D. R. Zimmerman (1979). Selection for ovulation rate in swine: Correlated response in litter size and weight. Journal of Animal Science, 48: 509-516.

Daniel, J. C. (2000). Discovery and perspectives from the blastokinin era. Annals of the New York Academy of Sciences, 923: 1-8.

Eady S. J. and H. Garreau (2007). Functional traits - can we find practical measures to quantify them and how important are they?. In: Proceeding Association for the Advancement of Animal Breeding and Genetics, Armidale, Australia. Volume 17: 495-498. 
EFSA (2005). The Impact of the current housing and husbandry systems on the health and welfare of farmed domestic rabbits. European Food Safety Authority Journal, 267: $1-31$.

Falconer, D. S. (1963). Qualitatively different responses to selection in opposite directions. In: Introduction to quantitative genetics. Prentice Hall, Essex, England. Pages: 487- 490.

Falconer, D. S. (1971). Improvement of litter size in a strain of mice at a selection limit. Genetics Research, 17: 215-235.

FAO-STAT. (2015). Statistics Data: Food and Agriculture organization. http://faostat3.fao.org/download/Q/QA/E

Fernández, E. N. (2016). Estimación de efectos genéticos aditivos y no aditivos en líneas maternales de conejos. Tesis Doctoral. Universidad Politécnica de Valencia, Valencia, España.

First, N. L. and M. J. Bosc (1979). Proposed mechanisms controlling parturition and the induction of parturition in swine. Journal of Animal Science, 48: 1407-1421.

Fleming, M. W., R. C. Rhodes and R. A. Dailey (1984). Compensatory responses after unilateral ovariectomy in rabbits. Biology of Reproduction, 30: 82-86.

Foote, R. H. and E. W. Carney (2000). The rabbit as a model for reproductive and developmental toxicity studies. Reproductive Toxicology, 14: 477-493.

Fujimoto, S., J. M. R. Rawson and W. R. Dukelow (1974). Hormonal influences on the time of ovulation in the rabbit as determined by laparoscopy. Journal of Reproduction and Fertility, 38: 97-103. 
García, M. L. (2001). Evaluación de la respuesta a la selección en dos líneas maternales de conejo. Tesis Doctoral. Universidad Politécnica de Valencia, Valencia, España.

García, M. L. and M. Baselga (2002a). Estimation of genetic response to selection in litter size of rabbits using a cryopreserved control population. Livestock Production Science, 74: 45-53.

García, M. L. and M. Baselga (2002c). Estimation of correlated response on growth traits to selection in litter size of rabbits using a cryopreserved control population and genetic trends. Livestock Production Science, 78: 91-98.

García, M. L. and M. Baselga. (2002b). Genetic response to selection for reproductive performance in a maternal line of rabbits. World Rabbit Science, 10: 71-76.

García-Ximenez, F. (1991). Manipulación de embriones de conejo: Técnicas básicas. Servicio de publicaciones de la Universidad Politécnica de Valencia, Valencia, España.

Garreau, H., Zs. Szendrö, C. Larzul and H. de Rochambeau (2000). Genetic parameters and genetic trends of growth and litter size traits in the White Pannon breed. In: Proceeding $7^{\text {th }}$ World Rabbit Congress, Valencia, Spain. Volume 1: 403-408.

Geisert, R. D. and R. A. M. Schmitt (2002). Early embryonic survival in the pig: Can it be improved?. Journal of Animal Science, 80 (Suppl. 1): E54-E65.

Gion, J. M., A. C. Clutter and M. K. Nielsen (1990). Alternative methods of selection for litter size in mice: II. Response to thirteen generations of selection. Journal of Animal Science, 68: 3543-3556. 
Gómez, E. A., M. Baselga, O. Rafel, and J. Ramon (1998). Comparison of carcass characteristics in five strains of meat rabbit selected on different traits. Livestock Production Science, 55: 53-64.

Hafez, E. S. E. (1969). Fetal survival in undercrowded and overcrowded unilaterally pregnant uteri in the rabbit. In: Proceeding $6^{\text {th }}$ International Congress on Animal Reproduction and Artificial Insemination, Paris, France. Volume 1: 575.

Haley, C. S., and G. J. Lee (1992). Genetic factors contributing to variation in litter size in British Large White gilts. Livestock Production Science, 30: 99-113.

Harper, M. J. K. (1961). The mechanism involved in the movement of newly ovulated eggs through the ampulla of the rabbit fallopian tube. Journal of Reproduction and Fertility, 2: 522-524.

Hill, M. A. (2016). Embryology. Rabbit development. https://embryology.med.unsw.edu.au/embryology/index.php/Rabbit_Developme nt

Joakimsen, O. and R. L. Baker (1977). Selection for litter size in mice. Acta Agriculturae Scandinavica, 27: 301-318.

Johnson, R. K., D. R. Zimmerman and R. J. Kittok (1984). Selection for components of reproduction in swine. Livestock Production Science, 11: 541-558.

Johnson, R. K., M. K. Nielsen and D. S. Casey (1999). Response in ovulation rate, embryonal survival and litter size traits in swine to 14 generations of selection to increase litter size. Journal of Animal Science, 77: 541-557.

Kirby, Y. K., and M. K. Nielsen (1993). Alternative methods of selection for litter size in mice: III. Response to 21 generations of selection. Journal of Animal Science, 71: $571-578$. 
Koenig, J. L. F., D. R. Zimmerman F. E. Eldrige and J. D. Kopf (1986). The effect of superovulation and selection for high ovulation rate on chromosomal abnormalities in swine ova. Journal of Animal Science, 63 (Suppl. 1): 202.

Krisher, R. L. (2004). The effect of oocyte quality on development. Journal of Animal Science, 82 (Suppl. 1): E14-E23.

Laborda P., L. Mocé, M. A. Santacreu and A. Blasco (2011). Selection for ovulation rate in rabbits: Genetic parameters, direct response and correlated response on litter size. Journal of Animal Science, 89: 2981-2987.

Laborda, P., M. A. Santacreu, A. Blasco and M. L. Mocé (2012b). Selection for ovulation rate in rabbits: direct and correlated responses estimated with a cryopreserved control population. Journal of Animal Science, 90: 3392-3397.

Laborda, P., M. L. Mocé, A. Blasco and M. A. Santacreu (2012a). Selection for ovulation rate in rabbits: Genetic parameters and correlated response on survival rates. Journal of Animal Science, 90: 439-446.

Land, R. B. and D. S. Falconer (1969). Genetic studies of ovulation rate in the mouse. Genetical Research, 13: 25-46.

Leiser, R. and P. Kaufmann (1994). Placental structure: in a comparative aspect. Experimental and Clinical Endocrinology, 102: 122-134.

Leymaster, K. A., and R. K. Christenson (2000). Direct and correlated responses to selection for ovulation rate or uterine capacity in swine. Journal of Animal Science, 78 (Suppl. 1): 68.

Long, C. R., W. R. Lamberson and R. O. Bates (1991). Genetic correlations among reproductive traits and uterine dimensions in mice. Journal of Animal Science, 69: 99-103. 
López Bejar, M. A. (1995). Evaluación de la viabilidad de embriones de conejo de diversos estadíos preimplantacionales crioconservados mediante procedimientos de congelación rápida. Tesis Doctoral. Universidad Autónoma de Barcelona, Barcelona, España.

McNitt, J. I., S. D. Lukefahr, P. R. Cheeke and N. M. Patton (2013). Rabbit production. CABI International publishing.

Mínguez, C., J. P. Sánchez, M. Ragab, A. G. El Nagar and M. Baselga (2012). Growth traits in four maternal lines. In: Proceeding $10^{\text {th }}$ World Rabbit Congress, Sharm El-Sheikh, Egypt. Volume 1: 55-59.

Mocé, L., M. A. Santacreu, A. Climent and A. Blasco (2005). Divergent selection for uterine capacity in rabbits. III. Responses on uterine capacity and its components estimated with a cryopreserved control population. Journal of Animal Science, 83: $2308-2312$.

Mocé, M. L. (2003). Maternal and embryonic genetic effects on prenatal survival in an experiment of divergent selection for uterine capacity in rabbit. Doctoral Thesis. Department of Animal Science, Polytechnic University of Valencia, Valencia, Spain.

Mocé, M. L., A. Blasco and M. A. Santacreu (2010). In vivo development of vitrified rabbit embryos: effects on prenatal survival and placental development. Theriogenology, 73: 704-710.

Mocé, M. L., M. A. Santacreu, A. Climent, and A. Blasco (2004). The effect of divergent selection for uterine capacity on prenatal survival in rabbits: Maternal and embryonic genetic effects. Journal of Animal Science, 82: 68-73. 
Neal, S. M., R. K. Johnson and R. J. Kittok (1989). Index selection for components of litter size in swine: Response to five generations of selection. Journal of Animal Science, 67: 1933-1945.

Nielsen, B., G. Su, M. S. Lund and P. Madsen (2013). Selection for increased number of piglets at day 5 after farrowing has increased litter size and reduced piglet mortality. Journal of Animal Science, 91: 2575-2582.

Nistor, E., V. A. Bampidis, N. Păcală, M. Pentea, J. Tozer and H. Prundeanu (2013). Nutrient Content of Rabbit Meat as Compared to Chicken, Beef and Pork Meat. Journal of Animal Production Advances, 3: 172-176.

Nofal, R., N. Hassan, A. Abdel-Ghany and V. Gyorgyi (2008). Estimation of genetic parameters for litter size and weight traits in NZW rabbits raised in Hungary. In: Proceeding $9^{\text {th }}$ World Rabbit Congress, Verona, Italy. Volume 1: 185-188.

Peiró, R., M. A. Santacreu, A. Climent and A. Blasco (2007). Early embryonic survival and embryo development in two divergent lines of rabbits selected for uterine capacity. Journal of Animal Science, 85: 1634-1639.

Piles, M., M. L. García, O. Rafel, J. Ramon and M. Baselga (2006). Genetics of litter size in three maternal lines of rabbits: Repeatability versus multiple-trait models. Journal of Animal Science, 84: 2309-2315.

Pope, W. F. (1988). Uterine asynchrony: A cause of embryonic loss. Biology of Reproduction, 39: 999-1003.

Quirino, C. R., R. Peiró, M. A. Santacreu and A. Blasco (2009). Genetic correlation between liveweight and ovulation rate in rabbits. In: Proceeding $60^{\text {th }}$ Annual Meeting of the European Association of Animal Science, Barcelona, Spain. Volume 1: 173. 
Ragab, M. (2012). Genetic analyses of reproductive traits in maternal lines of rabbits and in their diallel cross. Doctoral Thesis. Department of Animal Science, Polytechnic University of Valencia, Valencia, Spain.

Ragab, M. and M. Baselga (2011). A comparison of reproductive traits of four maternal lines of rabbits selected for litter size at weaning and founded on different criteria. Livestock Science, 136: 201-206.

Ribeiro, E. L., M. K. Nielsen, G. L. Bennett and K. A. Leymaster (1997a). A simulation model including ovulation rate, potential embryonic viability, and uterine capacity to explain litter size in mice: I. Model development and implementation. Journal of Animal Science, 75: 641-651.

Ribeiro, E. L., M. K. Nielsen, K. A. Leymaster and G. L. Bennett (1997b). A Simulation Model Including Ovulation Rate, Potential Embryonic Viability, and Uterine Capacity to Explain Litter Size in Mice: II. Responses to Alternative Criteria of Selection. Journal of Animal Science, 75: 652-656.

Rochambeau, H. de (1988). Genetic of rabbit for wool and meat production. In: Proceeding $4^{\text {th }}$ World Rabbit Congress, Budapest, Hungary. Volume 2: 1-68.

Rochambeau, H. de, G. Bolet and F. Tudela (1994). Long term selection. Comparison of two rabbit strains. In: Proceeding $5^{\text {th }}$ World Congress on Genetics Applied to Livestock Production, Guelph, Canada. Volume 19: 257-260.

Rochambeau, H. de, R. Duzert and F. Tudela (1998). Long term selection experiment in rabbit. Estimation of genetic progress on litter size at weaning. In: Proceeding $\sigma^{\text {th }}$ World Congress on Genetics Applied to Livestock Production, Armidale, Australia. Volume 26: 112-115. 
Rosell, J. M. (2000). Biología. In: Enfermedades del conejo. Mundi-prensa libros, Madrid, Spain. Pages: 55-127.

Rosendo, A. T, T. Druet, J. Gogué and J. P. Bidanel (2007a). Direct responses to six generations of selection for ovulation rate or prenatal survival in Large White pigs. Journal of Animal Science, 85: 356-364.

Rosendo, A., L. Canario, T. Druet, J. Gogué and J. P. Bidanel (2007b). Correlated responses of pre- and postweaning growth and backfat thickness to six generations of selection for ovulation rate or prenatal survival in French Large White pigs. Journal of Animal Science, 85: 3209-3217.

Rothschild, M. F. and J. P. Bidanel (1998). Biology and genetics of reproduction. In: The genetics of the pig. CAB International, Wallingford, United Kingdom. Pages: 313-343.

Ruíz-Flores, A. and R. K. Johnson. (2001). Direct and correlated responses to two-stage selection for ovulation rate and number of fully formed pigs at birth in swine. Journal of Animal Science, 79: 2286-2297.

Sánchez, J. P., P. Theilgaard, C. Mínguez and M. Baselga (2008). Constitution and evaluation of a long-lived productive rabbit line. Journal of Animal Science, 86: $515-525$.

Santacreu, M. A. (1992). Estimación de los parámetros genéticos de la tasa de ovulación, supervivencia prenatal y tamaño de camada en conejo. Tesis Doctoral. Universidad Politécnica de Valencia, Valencia, España.

Santacreu, M. A. (2006). La supervivencia prenatal en la coneja reproductora. In: Proceeding $31^{\text {st }}$ Symposium de Cunicultura, de ASESCU, Lorca (Murcia), Spain. Volume 1: 229-236. 
Santacreu, M. A., L. Mocé, A. Climent and A. Blasco (2005). Divergent selection for uterine capacity in rabbits. II Correlated response on litter size and its components estimated with a cryopreserved control population. Journal of Animal Science, 83: $2303-2307$.

Santacreu, M. A., M. J. Argente, A. Climent, A. Blasco and G. Bolet (1994). Divergent selection for uterine efficiency in unilaterally ovariectomized rabbits. II. Response to selection. In: Proceeding $5^{\text {th }}$ World Congress on Genetics Applied to Livestock Production, Guelph, Canada. Volume 19: 265- 267.

Santacreu, M. A., M. J. Argente, M. L. Mocé and A. Blasco (2000). Selection for uterine capacity. II. Response to selection estimated with a cryopreserved control population. In: Proceeding $7^{\text {th }}$ World Rabbit Congress, Valencia, Spain. Volume 1: 491-495.

Santacreu, M. A., M. P. Viudes and A. Blasco (1990). Evaluation par coelioscopie des corps jaunes et des embryons. Influence sur la taille de portee chez la lapine. Reproduction Nutrition Development, 30: 583-588.

Soede, N. M., C. C. H. Wetzels, W. Zondag, M. A. I. de Koning and B. Kemp (1995). Effects of time of insemination relative to ovulation, as determined by ultrasonography, on fertilization rate and accessory sperm count in sows. Journal of Reproduction and Fertility, 104: 99-106.

Soriano, J. J. (2014). Estudio del incremento de la tasa de ovulación sobre el desarrollo del feto y la supervivencia prenatal en conejo. Trabajo final de carrera. Universidad Politécnica de Valencia, Valencia, España. 
Spies, H. G., K. Y. Pau and S. P. Yang (1997). Coital and estrogen signals: a contrast in the preovulatory neuroendocrine networks of rabbits and rhesus monkeys. Biology of Reproduction, 56: 310-319.

Suttle, N. F. (2010). Mineral nutrition of livestock. CABI International, Oxfordshire, United Kingdom.

Szkucik, K. and R. Pyz-Łukasik (2009). Health quality of rabbit meat. Medycyna Weterynaryjna, 65: 665-669.

Theau-Clement, M., P. Salvetti, G. Bolet, G. Saleil and T. Joly (2009). Influence de l'intervalle entre le sevrage et l'insemination sur la production d'embryons et leur qualité chez la lapine. In: Proceeding $13^{\text {émes }}$ Journées de la Recherché Cunicole, Le Mans, France. Volume 1: 125-128.

Thibault, C, M. Gerard and Y. Menezo (1975). Preovulatory and ovulatory mechanisms in oocyte maturation. Journal of Reproduction and Fertility, 45: 605-610.

Torres, S. (1982). Etude de la mortalité embryonnaire chez la lapine. In: Proceeding $3^{\text {eme }}$ Congres Mondial de Cuniculture, Rome, Italy. Volume 2: 417-425.

Torres, S., F. Hulot and M. Meunier (1984). Étude comparée du développement et de la mortalité embryonnaire chez deux génotypes de lapines. In: Proceeding $3^{\text {rd }}$ World Rabbit Congress, Rome, Italy. Volume 2: 417-425.

Tudela, F., J. Hurtaud, H. Garreau and H. de Rochambeau (2003). Comparaison des performances zootechniques de femelles parentales issues d'une souche témoin et d'une souche sélectionnée sur la productivité numérique. In: Proceeding $10^{\text {èmes }}$ Journées Recherche Cunicole, Paris, France. Volume 1: 53-56. 
Vallet, J. L., R. K. Christenson, W. E. Trout and H. G. Klemcke (1998). Conceptus, progesterone, and breed effects on uterine protein secretion in swine. Journal of Animal Science, 76: 2657-2670.

Wilmut, I., D. I. Sales and C. J. Ashworth (1986). Maternal and embryonic factors associated with prenatal loss in mammals. Journal of Reproduction and Fertility, 76: 851-864.

Xie, S., D. M. Broermann, K. P. Nephew, R. D. Geisert and W. F. Pope (1990). Ovulation and early embryogenesis in swine. Biology of Reproduction, 43: 236240.

Young, L. D., I. T. Omtvedt and R. K. Johnson (1974). Relationships of various measures of performance with ovulation rate and number of embryos 30 days after breeding in gilts. Journal of Animal Science, 39: 480-487.

Yuan, T., Y. Zhu, M. Shi, T. Li, N. Li, G. Wu, F. W. Bazer, J. Zang, F. Wang and J. Wang (2015). Within-litter variation in birth weight: impact of nutritional status in the sow. Journal of Biomedicine and Biotechnology, 16: 417-435.

Zotte, D. A. (2000). Main factors influencing the rabbit carcass and meat quality. In: Proceeding $7^{\text {th }}$ World Rabbit Congress, Valencia, Spain. Volume 1: 507-537. 
CHAPTER TWO

OBJECTIVES 



\subsection{OBJECTIVES}

Litter size is an important economic trait in rabbit production. The general objective of this thesis is to evaluate the effect of selection for ovulation rate and litter size using independent culling levels aiming to increase the litter size.

The specific objectives of this thesis are to estimate:

1. Genetic direct response on ovulation rate and litter size.

2. Correlated response on number of implanted embryos and survival traits (embryo, foetal and prenatal survival).

3. Correlated response on growth traits (weight at 28 and 63 days old, and growth rate).

4. The effect of increased ovulation rate by hormonal treatment on embryo and foetal survival at 18 days of gestation as a model for selection by ovulation rate. 

CHAPTER THREE 



\section{CHAPTER 3}

Selection for Ovulation Rate and Litter Size Using Independent Levels in Rabbits: Genetic Parameters, Direct and Correlated Responses on Reproductive Traits

Acknowledgements: This study was supported by the Comisión Interministerial de Ciencia y Tecnología CICYT-AGL2011-29831-C03-01 and by funds from Generalitat Valenciana research programme (Prometeo 2009/125). A.Y. Badawy was supported by a grant of the Egyptian Ministry of Higher Education. 



\subsection{ABSTRACT}

This study was aiming to estimate the genetic parameters and response of reproductive traits in a rabbit line selected for ovulation rate and litter size. The experiment involved two selection periods. In the first one, selection was performed for ovulation rate, recorded by laparoscopy at day 12 of the second gestation. In the second one, selection was performed for ovulation rate and litter size using independent culling levels. Each generation consisted of about 75 females and 17 males, and the total selection pressure was around $30 \%$. The studied traits were ovulation rate (OR), number of implanted embryos (IE), number of live foetuses at 12 days of gestation $\left(\mathrm{LF}_{12}\right)$, litter size (LS), number of kits born alive (NBA), number of kits born dead (NBD), number of kits at weaning (NW) and number of rabbits at marketing (NM). Also survival rates, including embryo survival (ES) estimated as IE/OR, foetal survival (FS) estimated as LS/IE and prenatal survival (PS) estimated as LS/OR, were studied. Data was analysed using Bayesian inference methods. Heritability estimates were low for litter size traits: $0.10,0.07,0.07$ and 0.07 for LS, NBA, NW and NM, respectively. Heritability value was moderate for OR $(0.25)$ and low for IE and $\mathrm{LF}_{12}(0.13$ and 0.14 , respectively). Survival traits had low values of heritability, 0.09, 0.16 and 0.14 for ES, FS and PS, respectively. Although selection for ovulation rate during 6 generations improved OR ( 0.24 ova per generation), the correlated response on litter size was low (0.07 kits per generation). It was attributed to an increase of the prenatal mortality, especially during foetal period. However, an improvement in litter size was observed after 11 generations of selection for ovulation rate and litter size $(0.17$ kits per generation), due to the improvement in both components of litter size, OR ( 0.17 ova per generation) and PS (0.01 per generation). The improvement in PS was achieved by an increment of both ES and FS.

Keywords: selection, ovulation rate, litter size, survival traits, genetic response. 


\subsection{INTRODUCTION}

Litter size improvement is one of the major purposes in selection programs of commercial prolific species (rabbits and pigs). In rabbit maternal lines, improvement of litter size reduces the fixed cost (Cartuche et al., 2014). A low response was usually obtained after selection for litter size (Baselga, 2004 in rabbits and Blasco et al., 1993b in pigs). Since ovulation rate and prenatal survival are limiting factors for litter size in prolific species, selection for one or both of them was proposed as an indirect way to improve litter size. Response on ovulation rate was achieved by direct selection, but without a corresponding increase in litter size (Laborda et al., 2011 and 2012a in rabbits; Leymaster and Christenson, 2000 and Rosendo et al., 2007 in pigs; Bradford, 1969 and Land and Falconer, 1969 in mice). The low correlated response on litter size is attributed to the increase in prenatal mortality (Laborda et al., 2012a). Actually, around $20-40 \%$ of shed ova are lost during the pregnancy in rabbits, pigs and mice (reviewed by Blasco et al., 1993b). Therefore, an increase of prenatal survival should be a way to improve litter size. Bennet and Leymaster (1989) proposed selection for uterine capacity as a way to change prenatal survival, since it was defined as the maximum number of fetuses that a female is able to support at birth when ovulation rate is not a limiting factor. Selection for prenatal survival or uterine capacity causes an increase in litter size but not higher than the response obtained by direct selection (Santacreu et al., 2005 in rabbits; Rosendo et al., 2007 in pigs; Gion et al., 1990 in mice). Similar results were found after selection by an index combining ovulation rate and prenatal survival (Johnson et al., 1999 in pigs; Kirby and Nielsen, 1993 in mice), probably due to the sensitivity of the selection index to the genetic correlation value (Falconer and Mackay, 1996), which is usually estimated with low accuracy. In pigs, higher response on litter size than direct selection was obtained after performing a 2- 
stage selection procedure for litter size and ovulation rate (Ruiz-Flores and Johnson, 2001). Hence, the aim of this study was to estimate the genetic parameters and genetic responses on litter size and its components in a rabbit line, previously selected for ovulation rate during six generations, and subsequently selected by independent culling levels for ovulation rate and litter size during 11 generations.

\subsection{MATERIALS AND METHODS}

All experimental procedures involving animals were approved by the Universitat Politècnica de València Research Ethics Committee.

\subsubsection{Animals and experimental design}

Animals involved in this study came from a line (OR-LS) whose origin was the synthetic line (V line) first selected for litter size at weaning for 12 generations (García and Baselga, 2002a), then for high uterine capacity for 10 generations (Blasco et al., 2005), and then selection was relaxed for 6 generations. From there, founders were chosen at random within families to create the line OR-LS.

Line OR-LS underwent 17 generations of selection. From base generation to generation 6 (first selection period), females were selected only for ovulation rate at second gestation estimated by laparoscopy. From generation 7 to 17 (second selection period), a 2-stage selection for ovulation rate and litter size was performed. In stage 1, females having the highest ovulation rate at second gestation were selected. In stage 2, selection was for the highest average litter size of the first two parities of those females selected in stage 1 . There were no generations of relaxed selection between these periods of selection. Until the $6^{\text {th }}$ generation, selection pressure in females was about $30 \%$. From generation 7 to 17 , selection pressure was about 65 and $50 \%$ for ovulation rate and litter size, respectively. Males were selected within families from litters of best 
dams. The number of females and males was around 75 and 17 per generation, respectively.

Does were mated for the first time at 18 to 20 weeks of age, and 11 to 12 days after each parturition. Females that did not accept males were mated again one week afterward. Pregnancy was checked approximately 12 days after mating by abdominal palpation. Animals were housed at the farm of the Universitat Politècnica de València in individual cages (flat-deck) having extractable nest box with isolated plastic. Animals were reared under a photoperiod of 16-hours light: 8-hours dark and controlled temperature and ventilation. Animals were fed with a commercial diet supplied ad libitum (16.5\% crude protein, $15.0 \%$ crude fiber and $3.0 \%$ fat $)$.

\subsubsection{Traits}

Ovulation rate (OR), estimated as the number of corpora lutea in both ovaries, number of implanted embryos (IE), estimated as the number of implantation sites, and the number of live foetuses at 12 days of gestation $\left(\mathrm{LF}_{12}\right)$, estimated as the number of live foetuses (distinguishing live from dead foetuses by size and colour), were measured by laparoscopy at day 12 of second gestation and post-mortem in the last gestation (from $3^{\text {rd }}$ to $6^{\text {th }}$ gestation) of the females. Laparoscopy is an accurate technique for measuring these traits without affecting litter size (Santacreu et al., 1990). Litter size (LS), measured as total number of kits born, and number of kits born alive (NBA) and dead (NBD) were recorded. Number of kits at weaning (NW; 28 days of age) and number of rabbits at marketing (NM; 63 days of age) per litter were also recorded in up to five parities.

Embryo survival (ES) was estimated as IE/OR, foetal survival (FS) was estimated as LS/IE and prenatal survival (PS) was estimated as LS/OR. Data from 1210 
laparoscopy and 4480 parities were analysed. Number of records for each trait is presented in Table 3.1. The number of animals in the pedigree was 30,666.

\subsubsection{Statistical Analysis}

Data from 17 generations (6 from first selection period and 11 from second one) was analysed using Bayesian inference methods. Repeatability animal models were fitted to estimate the genetic parameters and genetic response for all traits except FS and PS, where the animal model was fitted. Genetic parameters and correlations between OR and LS were estimated using a bivariate model. Trivariate analysis included OR, LS and one of the remaining traits.

The model used to analyse the data for all traits (except FS and PS) was:

$$
y_{i j k l}=Y S_{i}+P H Y S_{j}+a_{k}+p_{k}+e_{i j k l}
$$

in which, $y_{i j k l}$ is the record of the trait, $Y S_{i}$ is the effect of year season (three months per each year season; 49 levels for litter size traits; 44 levels for OR, IE, $\mathrm{LF}_{12}$ and ES), $P H Y S_{j}$ is the effect of physiological status at mating (five levels for litter size traits; nulliparous, lactating primiparous, non-lactating primiparous, lactating multiparous and non-lactating multiparous; the latest four levels for OR, IE, $\mathrm{LF}_{12}$ and ES), $a_{k}$ is the additive value of the animal $\mathrm{k}, p_{k}$ is the permanent environmental non-additive effect of the female $\mathrm{k}$, and $e_{i j k l}$ is the residual of the model. Number of kits born dead (NBD) was analysed as a threshold trait, divided into three classes (zero; from one to three; more than three).

The model used to analyse FS and PS was:

$$
y_{i j k}=Y S_{i}+P H Y S_{j}+a_{k}+e_{i j k}
$$

in which, $Y S_{i}$ is the effect of year season (38 levels), $P H Y S_{j}$ is the effect of physiological status at mating (two levels; lactating and non-lactating primiparous), $a_{k}$ is the additive value of the animal $\mathrm{k}$, and $e_{i j k}$ is the residual of the model. 
For the bivariate repeatability model, the traits were assumed to be conditionally normally distributed as follows:

$$
\left[\begin{array}{l}
\mathbf{y}_{1} \\
\mathbf{y}_{2}
\end{array}\right] \mid \mathbf{b}_{1}, \mathbf{b}_{2}, \mathbf{a}_{1}, \mathbf{a}_{2}, \mathbf{p}_{1}, \mathbf{p}_{2}, \mathbf{R} \sim \mathbf{N}\left(\mathbf{X}\left[\begin{array}{l}
\mathbf{b}_{1} \\
\mathbf{b}_{2}
\end{array}\right]+\mathbf{Z}\left[\begin{array}{l}
\mathbf{a}_{1} \\
\mathbf{a}_{2}
\end{array}\right]+\mathbf{W}\left[\begin{array}{l}
\mathbf{p}_{1} \\
\mathbf{p}_{2}
\end{array}\right], \mathbf{R}\right)
$$

in which $\mathbf{b}_{1}$ and $\mathbf{b}_{2}$ were random vectors including the effects of YS and PHYS; $\mathbf{a}_{1}$ and a2 were vectors of individual additive genetic effects; $\mathbf{p}_{1}$ and $\mathbf{p}_{2}$ were vectors of permanent environmental effects. $\mathbf{X}, \mathbf{Z}$ and $\mathbf{W}$ were known incidence matrices; $\mathbf{R}$ was the residual (co)variance matrix. Between individuals, only the additive random effects were assumed correlated. Between traits, the additive, the permanent environmental and the residual effects were assumed correlated. The residual (co)variance matrix can be written as $\mathbf{R}_{\mathbf{0}} \otimes \mathbf{I}_{\mathbf{n}}$, with $\mathbf{R}_{\mathbf{0}}$ being the $2 \times 2$ residual (co)variance matrix between the traits analyzed and $\mathbf{I}_{\mathbf{n}}$ an identity matrix of appropriate order. Bounded uniform priors were used to represent vague previous knowledge of distributions of $\mathbf{b}_{1}$ and $\mathbf{b}_{2}$. Prior knowledge concerning additive and permanent effects was represented by assuming that they were normally distributed, conditionally on the associated (co)variance components, as follows:

$$
\left[\begin{array}{l}
\mathbf{a} 1 \\
\mathbf{a} 2
\end{array}\right]\left|\mathbf{G} \sim \mathbf{N}(\mathbf{0 , G}) \quad\left[\begin{array}{l}
\mathbf{p} 1 \\
\mathbf{p} 2
\end{array}\right]\right| \mathbf{P} \sim \mathbf{N}(\mathbf{0 , P})
$$

in which 0 is a vector of zeroes, $\mathbf{G}$ is the genetic (co)variance matrix and $\mathbf{P}$ is the (co)variance matrix of the permanent environmental non-additive effects of the doe. Matrices $\mathbf{G}$ and $\mathbf{P}$ could be written as $\mathbf{G}_{\mathbf{0}} \otimes \mathbf{A}$ and $\mathbf{P}_{\mathbf{0}} \otimes \mathbf{I}_{\mathbf{s}}$, respectively, where $\mathbf{G}_{\mathbf{0}}$ and $\mathbf{P}_{0}$ were the $2 \times 2$ genetic and permanent (co)variance matrices, $\mathbf{A}$ is the known additive genetic relationship matrix and $\mathbf{I}_{\mathbf{s}}$ the identity matrix of the same order as the number of levels of permanent effects. Bounded uniform priors were used for the components 
of the (co)variance matrices $\mathbf{R}_{\mathbf{0}}$ and $\mathbf{G}_{\mathbf{0}}$ and $\mathbf{P}_{\mathbf{0}}$. For trivariate repeatability analyses, the order of $\mathbf{R}, \mathbf{G}$ and $\mathbf{P}$ matrices was $3 \times 3$.

Marginal posterior distributions of all unknowns were estimated by using the Gibbs sampling algorithm. The data vector was augmented to have the same design matrices for all traits. Augmented data were not used for inferences but simplified computing by sampling from a predictive distribution of missing data (Sorensen and Gianola, 2002). The program TM developed by Legarra et al. (2008) was used for all Gibbs sampling procedures. After some exploratory analyses, chains of 3,000,000 samples were used, with a burn in period of 750,000 (except for ES; 1,200,000). One sample each 100 were saved to avoid high correlations between consecutive samples. Convergence was tested using the $\mathrm{Z}$ criterion of Geweke (Sorensen and Gianola, 2002).

\subsection{RESULTS AND DISCUSSION}

Means, standard deviations (SD) and coefficient of variation (CV) for all studied traits are shown in Table 3.1. Our results for litter size traits are in agreement with values published by other authors in maternal rabbit lines (García and Baselga, 2002a and Laborda et al., 2012b in rabbits; Blasco et al., 1996 and Johnson et al., 1999 in pigs), as well as ovulation rate (García and Baselga, 2002a; Argente et al., 2000 in rabbits; Blasco et al., 1996 and Johnson et al., 1999 in pigs; Clutter et al., 1990 in mice) and survival traits (García and Baselga, 2002a; in rabbits; Blasco et al., 1996 and Johnson et al., 1999 in pigs). For NBD, the coefficient of variation was out of range because the data are not normally distributed and approximately $50 \%$ of data is zero. 
Table 3.1. Descriptive analysis for ovulation rate (OR, ova), number of implanted embryos (IE), number of live foetus at 12 days of gestation $\left(\mathrm{LF}_{12}\right)$, litter size (LS, total number of kits born), number of kits born alive (NBA), number of kits born dead (NBD), number of kits at weaning (NW), number of rabbits at marketing (NM), embryo survival (ES), foetal survival (FS) and prenatal survival (PS).

\begin{tabular}{lcccccc}
\hline \multicolumn{1}{c}{ Trait } & N & Mean & SD & CV (\%) & Min. & Max. \\
\hline OR & 2013 & 16.04 & 2.63 & 16.38 & 8 & 26 \\
IE & 1566 & 12.28 & 3.84 & 31.30 & 1 & 23 \\
LF12 & 1539 & 11.50 & 3.99 & 34.69 & 0 & 22 \\
LS & 4480 & 9.09 & 3.18 & 35.02 & 1 & 19 \\
NBA & 4480 & 8.13 & 3.42 & 42.11 & 0 & 18 \\
NBD & 4480 & 0.96 & 1.85 & 192.75 & 0 & 16 \\
NW & 4474 & 7.10 & 3.23 & 45.53 & 0 & 16 \\
NM & 4439 & 6.76 & 3.23 & 47.73 & 0 & 16 \\
ES & 1566 & 0.764 & 0.220 & 28.76 & 0.053 & 1.000 \\
FS & 1108 & 0.761 & 0.175 & 22.95 & 0.067 & 1.000 \\
PS & 1121 & 0.589 & 0.200 & 33.96 & 0.048 & 1.000 \\
\hline N- Num & & & & & &
\end{tabular}

$\mathrm{N}=$ Number of data, $\mathrm{SD}=$ Standard deviation, $\mathrm{CV}=$ Coefficient of variation, Min. = Minimum, Max. $=$ Maximum.

\subsubsection{Genetic parameters}

In all analyses, mean and median were similar for all traits because the marginal posterior distributions were symmetric. Monte Carlo standard errors were small; no lack of convergence was detected by Geweke test.

\subsubsection{Heritability}

Features of the marginal posterior distributions of the heritability are shown in Table 3.2. The heritability estimates for OR was moderate, 0.25 , having a probability of $95 \%$ of being at least 0.18 . Heritability value decreased from ovulation up to parturition. Besides, values representing at least $95 \%$ of probability ( $\mathrm{k}$ value in the Table) were also reduced for these traits. Hence, in the day 12 of gestation, heritability 
estimates and $\mathrm{k}$ values for IE and $\mathrm{LF}_{12}$ were lower than OR. Litter size had a low heritability $(0.10)$ and the high posterior density interval at $95 \%$ ranging from 0.05 to 0.14. Afterward, similar heritabilities to LS were obtained for NBA, NW and NM (0.07). The estimated heritability for NBD, analyzed as threshold trait, was 0.14 .

Heritability values for ES, FS and PS were low, approximately 0.10 for ES and 0.15 for both FS and PS (Table 3.3). The probability of the heritability being higher than 0.10 was close to $100 \%$ for both FS and PS and with a probability of $95 \%$ of being at least 0.09 and 0.10 , respectively.

Generally, estimated heritabilities for litter size traits were in agreement with other studies evaluating rabbit maternal lines (Blasco et al., 1993a; Rochambeau et al., 1994; Ayyate et al., 1995; Lukefahr and Hamilton, 1997; Cifre et al., 1998; Argente et al., 2000; Garcia and Baselga, 2002a; Piles et al., 2006; Ragab, 2012; Nagy et al., 2013 and Fernández, 2016). Ruiz-Flores and Johnson (2001) reported a higher heritability estimate for NBD in pigs $(0.29 \pm 0.05)$.

For ovulation rate, similar heritability was published by Laborda et al. (2011) from a rabbit line selected for ovulation rate during 10 generations. However, higher estimated heritabilities were reported in pigs ( 0.42 by Ruiz-Flores and Johnson, 2001; 0.34 by Rosendo et al., 2007) and mice $(0.33$ by Clutter et al., 1990) than in rabbits. Ziadi et al. (2013) suggested the difference in OR heritability may be due to the dissimilarity in ovulation mechanism; rabbit ovulation is induced by the coitus. Survival traits and IE showed also similar values to those obtained by Laborda et al. (2012a) as previously quoted. Data from the first period of selection for ovulation rate of our experiment were coincident with the first six generations from Laborda et al. (2011 and 2012a). 
Table 3.2. Features of the marginal posterior distributions of the heritability $\left(h^{2}\right)$ of ovulation rate (OR), number of implanted embryos (IE), number of live foetus at 12 days of gestation $\left(\mathrm{LF}_{12}\right)$, litter size (LS, total number of kits born), number of kits born alive (NBA), number of kits born dead (NBD), number of kits at weaning (NW) and number of rabbits at marketing (NM).

\begin{tabular}{|c|c|c|c|c|c|}
\hline \multirow{2}{*}{ Trait } & \multicolumn{2}{|c|}{$h^{2}$} & \multirow{2}{*}{$P_{0.10}$} & \multirow{2}{*}{ HPD95\% } & \multirow{2}{*}{$\boldsymbol{k}$} \\
\hline & Mean & SD & & & \\
\hline OR & 0.25 & 0.04 & 1.00 & {$[0.17,0.33]$} & 0.18 \\
\hline IE & 0.13 & 0.03 & 0.87 & {$[0.08,0.19]$} & 0.09 \\
\hline $\mathbf{L F}_{12}$ & 0.14 & 0.03 & 0.91 & {$[0.08,0.19]$} & 0.09 \\
\hline LS & 0.10 & 0.02 & 0.43 & {$[0.05,0.14]$} & 0.06 \\
\hline NBA & 0.07 & 0.02 & 0.08 & {$[0.04,0.11]$} & 0.05 \\
\hline NBD & 0.14 & 0.03 & 0.92 & {$[0.08,0.21]$} & 0.09 \\
\hline NW & 0.07 & 0.02 & 0.15 & {$[0.04,0.12]$} & 0.04 \\
\hline NM & 0.07 & 0.02 & 0.09 & {$[0.04,0.11]$} & 0.05 \\
\hline
\end{tabular}

$\mathrm{SD}=$ Standard deviation; $P_{0.10}=$ Probability of the heritability being higher than $0.10 ; \mathrm{HPD}_{95 \%}=$ High posterior density interval at $95 \% ; k=$ Limit for the interval $[k,+1)$ of the heritability having a probability of $95 \%$.

Table 3.3. Features of the marginal posterior distributions of the heritability $\left(h^{2}\right)$ of embryonic survival (ES), foetal survival (FS) and prenatal survival (PS).

\begin{tabular}{|c|c|c|c|c|c|}
\hline \multirow{2}{*}{ Trait } & \multicolumn{2}{|c|}{$h^{2}$} & \multirow{2}{*}{$P_{0.10}$} & \multirow{2}{*}{ HPD95\% } & \multirow{2}{*}{$\boldsymbol{k}$} \\
\hline & Mean & SD & & & \\
\hline $\mathbf{E S}$ & 0.09 & 0.03 & 0.37 & {$[0.04,0.15]$} & 0.05 \\
\hline FS & 0.16 & 0.05 & 0.93 & {$[0.08,0.25]$} & 0.09 \\
\hline PS & 0.14 & 0.02 & 0.98 & {$[0.10,0.19]$} & 0.10 \\
\hline
\end{tabular}

$\mathrm{SD}=$ Standard deviation; $P_{0.10}=$ Probability of the heritability being higher than $0.10 ; \mathrm{HPD}_{95 \%}=$ High posterior density interval at $95 \% ; k=$ Limit for the interval $[k,+1)$ of the heritability having a probability of $95 \%$. 


\subsubsection{Repeatability $(r)$}

Features of the marginal posterior distributions of the repeatability for litter size traits, OR and ES are shown in Table (3.4). Similar to the heritabilities, repeatability estimations were decreased from ovulation (0.30) up to parturition (approximately 0.15 for all litter size traits). The permanent environmental effects on litter size traits have to be similar, since these traits showed similar heritabilities and repeatabilities.

Table 3.4. Features of the marginal posterior distributions of the repeatability $(r)$ for ovulation rate (OR), number of implanted embryos (IE), number of live foetus at 12 days of gestation ( $\mathrm{LF}_{12}$ ), embryo survival (ES), litter size (LS, total number of kits born), number of kits born alive (NBA), number of kits born dead (NBD), number of kits at weaning (NW) and number of rabbits at marketing $(\mathrm{NM})$.

\begin{tabular}{lccc}
\hline \multicolumn{1}{c}{ Trait } & Repeatability $(\boldsymbol{r})$ & HPD95\% & $\boldsymbol{k}$ \\
\hline OR & 0.30 & {$[0.24,0.37]$} & 0.25 \\
IE & 0.22 & {$[0.16,0.28]$} & 0.19 \\
LF12 & 0.22 & {$[0.16,0.28]$} & 0.17 \\
ES & 0.18 & {$[0.11,0.24]$} & 0.13 \\
LS & 0.17 & {$[0.13,0.20]$} & 0.14 \\
NBA & 0.16 & {$[0.13,0.19]$} & 0.13 \\
NBD & 0.24 & {$[0.19,0.30]$} & 0.20 \\
NW & 0.14 & {$[0.11,0.17]$} & 0.11 \\
NM & 0.13 & {$[0.10,0.16]$} & 0.11 \\
\hline
\end{tabular}

$\mathrm{HPD}_{95 \%}=$ High posterior density interval at $95 \% ; k=$ Limit for the interval $[k,+1)$ of the repeatability having a probability of $95 \%$.

Little information is available about the estimated repeatabilities for litter size components in prolific species. Similar estimations were found for OR, IE, $\mathrm{LF}_{12}$ and ES in rabbit maternal lines selected by OR (Laborda et al., 2012a). Similar repeatability values for litter size traits were also obtained by Rochambeau et al. (1994), Ayyate et 
al. (1995), Lukefahr and Hamilton (1997), Cifre et al. (1998), Garcia and Baselga (2002a), Ragab (2012) and Fernández (2016).

Repeatability of NBD was moderate (0.24) with HPD interval at $95 \%$ being from 0.19 to 0.30 . To our knowledge, there is no information about repeatability of NBD in rabbits.

\subsubsection{Genetic correlations between litter size and other traits}

Features of the marginal posterior distributions of the genetic correlation between litter size and other analyzed traits are shown in Table (3.5). All high posterior density intervals at $95 \%\left(\mathrm{HPD}_{95 \%}\right)$ for genetic correlation between LS and other traits were large. The estimate of genetic correlation between LS and OR was positive and moderate $(0.37)$. The probability that the genetic correlation between these traits was positive was $99 \%$ and the value representing at least $95 \%$ of probability was 0.11 .

From ovulation up to parturition, genetic correlation of LS and other traits increased. High positive genetic correlations between LS and both IE and $\mathrm{LF}_{12}$ were found ( 0.73 and 0.76 , respectively). The genetic correlation of LS with NBA was close to one $(0.89)$, as expected. The $\mathrm{k}$ value of this genetic correlation was also high, 0.81 . Similar genetic correlations of LS with NW and NM were obtained $(0.81$ and 0.78 , respectively). These results indicated that increasing litter size at birth will increase the number of kits at weaning and marketing. On the other hand, no genetic correlation was found between $\operatorname{LS}$ and NBD $(0.01 ; \mathrm{P}>0=0.51)$. Genetic correlations between LS and survival rate traits were found positive and ranged from moderate (with ES and FS) to high (with PS). 
Table 3.5. Features of the marginal posterior distributions of the genetic correlation $\left(\boldsymbol{r}_{\boldsymbol{g}}\right)$ between litter size (LS, total number of kits born) and ovulation rate (OR), number of implanted embryos (IE), number of live foetus at 12 days of gestation $\left(\mathrm{LF}_{12}\right)$, number of kits born alive (NBA), number of kits born dead (NBD), number of kits at weaning (NW), number of rabbits at marketing (NM), embryo survival (ES), foetal survival (FS) and prenatal survival (PS).

\begin{tabular}{|c|c|c|c|c|c|}
\hline \multirow{2}{*}{ Trait } & \multicolumn{2}{|c|}{$r_{g}$} & \multirow{2}{*}{$\boldsymbol{P}$} & \multirow{2}{*}{ HPD95\% } & \multirow{2}{*}{$\boldsymbol{k}$} \\
\hline & Mean & SD & & & \\
\hline OR & 0.37 & 0.15 & 0.99 & {$[0.07,0.66]$} & 0.11 \\
\hline IE & 0.73 & 0.10 & 1.00 & {$[0.52,0.91]$} & 0.54 \\
\hline $\mathbf{L F}_{12}$ & 0.76 & 0.08 & 1.00 & {$[0.61,0.91]$} & 0.62 \\
\hline NBA & 0.89 & 0.04 & 1.00 & {$[0.80,0.96]$} & 0.81 \\
\hline NBD & 0.01 & 0.21 & 0.51 & {$[-0.39,0.41]$} & -0.34 \\
\hline NW & 0.81 & 0.09 & 1.00 & {$[0.64,0.97]$} & 0.64 \\
\hline NM & 0.78 & 0.09 & 1.00 & {$[0.62,0.93]$} & 0.62 \\
\hline ES & 0.59 & 0.15 & 1.00 & {$[0.30,0.85]$} & 0.32 \\
\hline FS & 0.47 & 0.15 & 0.99 & {$[0.18,0.74]$} & 0.21 \\
\hline PS & 0.81 & 0.04 & 1.00 & {$[0.73,0.89]$} & 0.74 \\
\hline
\end{tabular}

$\mathrm{SD}=$ Standard deviation; $P=$ Probability of the genetic correlation being higher than zero; $\mathrm{HPD}_{95 \%}=$ High posterior density interval at $95 \%$; $k=$ Limit for the interval $[k,+1)$ of the genetic correlation having a probability of $95 \%$.

Similar genetic correlation between LS and OR was observed in rabbits by Blasco et al. (1993a) and Argente et al. (1997). On the contrary, Laborda et al. (2011) reported a value of -0.20 with a very large $\mathrm{HPD}_{95 \%}$ as a genetic correlation between LS and OR. In pigs, Rosendo et al. (2007) reported similar genetic correlation between LS and OR, while Ruiz-Flores and Johnson (2001) showed a higher value for this correlation (0.52). Besides, Ruiz-Flores and Johnson (2001) found a low correlation between LS with NBD (0.20). Estimated genetic correlations between LS and other litter size traits are in agreement with García and Baselga (2002 a,b). For the correlation estimates of LS with survival rates, similar values were obtained by Blasco et al. (1993a), Argente et 
al. (1997) and Laborda et al. (2012a). In pigs, Johnson et al. (1999) reported 0.85 as a genetic correlation value between LS and IE.

\subsubsection{Genetic correlations between ovulation rate and other traits}

Features of the marginal posterior distributions of the genetic correlation between OR and other analyzed traits are shown in Table (3.6). These genetic correlations were estimated with low precision since it is difficult to have a large numbers of records of traits measured by laparoscopy.

Moderate-high genetic correlations between OR and each of IE and $\mathrm{LF}_{12}$ were found ( 0.65 and 0.67 , respectively). A reduction in the genetic correlation was observed at parturition, as it was quoted before (0.37). The genetic correlations between OR and NBA was low, similar with both NW and NM. Generally, genetic correlation between OR and the other analyzed traits gradually decreased as the difference between them in timing period increased. For survival traits, no genetic correlation between OR and ES was found. However, negative and moderate genetic correlations for OR with FS and PS (-0.46 and -0.28 , respectively) were observed. Moreover, the probability of $95 \%$ of being at least -0.24 and -0.10 , respectively ( $\mathrm{k}$ value). On the other hand, a moderate positive genetic correlation between OR and NBD was observed. Genetic correlations between traits were estimated with low accuracy, but they are within the range of estimates published by Blasco et al. (1993a), Argente et al. (2000) and Laborda et al. (2012b) in rabbits. Null or low (positive and negative) genetic correlations between OR and litters size traits were found in pigs (Ruiz-Flores and Johnson, 2001) and Johnson et al. (1999) and mice (Clutter et al., 1990). Besides, similar to our results, positive and moderate-high genetic correlation between OR and NBD (0.62) was found by RuizFlores and Johnson (2001). All the estimations showed a low accuracy since a small set of data were available for components of litter size. 
Table 3.6. Features of the marginal posterior distributions of the genetic correlation $\left(\boldsymbol{r}_{\boldsymbol{g}}\right)$ between ovulation rate (OR) and number of implanted embryos (IE), number of live foetus at 12 days of gestation $\left(\mathrm{LF}_{12}\right)$, number of kits born alive (NBA), number of kits born dead (NBD), number of kits at weaning (NW), number of rabbits at marketing (NM), embryo survival (ES), foetal survival (FS) and prenatal survival (PS).

\begin{tabular}{|c|c|c|c|c|c|}
\hline \multirow{2}{*}{ Trait } & \multicolumn{2}{|c|}{$r_{g}$} & \multirow{2}{*}{$\boldsymbol{P}$} & \multirow{2}{*}{ HPD95\% } & \multirow{2}{*}{$\boldsymbol{k}$} \\
\hline & Mean & SD & & & \\
\hline IE & 0.65 & 0.10 & 1.00 & {$[0.45,0.84]$} & 0.47 \\
\hline $\mathbf{L F}_{12}$ & 0.67 & 0.11 & 1.00 & {$[0.43,0.86]$} & 0.46 \\
\hline NBA & 0.12 & 0.16 & 0.78 & {$[-0.18,0.43]$} & -0.14 \\
\hline NBD & 0.55 & 0.13 & 1.00 & {$[0.30,0.81]$} & 0.34 \\
\hline NW & 0.02 & 0.18 & 0.53 & {$[-0.31,0.35]$} & -0.27 \\
\hline NM & 0.06 & 0.16 & 0.64 & {$[-0.26,0.36]$} & -0.21 \\
\hline ES & -0.08 & 0.19 & 0.68 & {$[-0.44,0.28]$} & 0.24 \\
\hline FS & -0.46 & 0.13 & 1.00 & {$[-0.71,-0.21]$} & -0.24 \\
\hline PS & -0.28 & 0.10 & 0.99 & {$[-0.47,-0.07]$} & -0.11 \\
\hline
\end{tabular}

$\mathrm{SD}=$ Standard deviation; $P=$ Probability of the genetic correlation being higher than zero when the mean is positive or lower than zero when it is negative; $\mathrm{HPD}_{95 \%}=$ High posterior density interval at $95 \%$; $k=$ Limit for the interval $[k,+1)$ of the genetic correlation having a probability of $95 \%$ when the mean is positive or limit for the interval $(-1, k]$ when it is negative.

\subsubsection{Correlations between permanent effects}

Correlation between permanent effects for LS and OR was positive $(\mathrm{P}=0.92)$ and moderate (0.51; Table 3.7), although the estimation had a low accuracy. The estimated correlations of LS with ES, IE and LF12 were higher, the $\mathrm{k}$ values were $0.35,0.49$ and 0.74, respectively. Correlation between permanent effects of LS with NBA was also high, 0.81 , and the high posterior density interval at $95 \%$ ranged from 0.70 to 0.90 . Permanent effects for NW and NM showed positive moderate correlations with permanent effects of LS, around 0.50. Therefore, as it was expected, the environmental permanent effects influencing LS affect in the same sense their components traits and 
also the weaned and marketing litter size. Similar correlations between permanents effects of OR with the other analyzed traits were estimated, except for ES and NBD.

Table 3.7. Features of the marginal posterior distributions of the correlation between permanent effects $\left(r_{\text {permanent }}\right)$ for litter size (LS, total number of kits born) and ovulation rate (OR) with number of implanted embryos (IE), number of live foetus at 12 days of gestation ( $\left.\mathrm{LF}_{12}\right)$, embryo survival (ES), number of kits born alive (NBA), number of kits born dead (NBD), number of kits at weaning (NW) and number of rabbits at marketing (NM).

\begin{tabular}{lccccc}
\hline \multirow{2}{*}{ Trait } & \multicolumn{2}{c}{$\boldsymbol{r}_{\text {permanent }}$} & \multirow{2}{*}{$\boldsymbol{P}$} & HPD95\% & $\boldsymbol{k}$ \\
\cline { 2 - 4 } & Mean & SD & & & \\
\hline LS, OR & 0.51 & 0.35 & 0.92 & {$[-0.10,1.00]$} & -0.10 \\
LS, IE & 0.81 & 0.17 & 1.00 & {$[0.49,1.00]$} & 0.49 \\
LS, LF 12 & 0.91 & 0.10 & 1.00 & {$[0.74,1.00]$} & 0.74 \\
LS, ES & 0.72 & 0.20 & 1.00 & {$[0.35,1.00]$} & 0.35 \\
LS, NBA & 0.81 & 0.06 & 1.00 & {$[0.70,0.90]$} & 0.71 \\
LS, NBD & 0.25 & 0.26 & 0.84 & {$[-0.26,0.68]$} & -0.21 \\
LS, NW & 0.52 & 0.20 & 0.98 & {$[0.16,0.84]$} & 0.18 \\
LS, NM & 0.53 & 0.18 & 0.98 & {$[0.12,0.80]$} & 0.14 \\
\hline OR, IE & 0.48 & 0.28 & 0.94 & {$[-0.06,0.99]$} & -0.05 \\
OR, LF12 & 0.32 & 0.30 & 0.80 & {$[-0.22,0.83]$} & -0.19 \\
OR, ES & 0.01 & 0.41 & 0.50 & {$[-0.72,0.68]$} & -0.67 \\
OR, NBA & 0.72 & 0.17 & 1.00 & {$[0.40,0.98]$} & 0.41 \\
OR, NBD & -0.59 & 0.23 & 0.98 & {$[-0.99,-0.17]$} & -0.17 \\
OR, NW & 0.72 & 0.22 & 0.99 & {$[0.32,0.99]$} & 0.32 \\
OR, NM & 0.77 & 0.19 & 1.00 & {$[0.39,0.99]$} & 0.40 \\
\hline SD
\end{tabular}

$\mathrm{SD}=$ Standard deviation; $P=$ Probability of the correlation between permanent effects being higher than zero when the mean is positive or lower than zero when it is negative; $\mathrm{HPD}_{95 \%}=$ High posterior density interval at $95 \%$; $k=$ Limit for the interval $[k,+1)$ of the correlation between permanent effects having a probability of $95 \%$ when the mean is positive or limit for the interval $(-1, k]$ when it is negative.

\subsubsection{Phenotypic correlations}

Features of the estimated marginal posterior distributions of the phenotypic correlations of LS and OR with the other traits are showed in Tables 3.8 and 3.9. Mainly, phenotypic correlation values between different traits had the same attitude and sign as the genetic correlation. Low positive phenotypic correlation between OR and 
LS was estimated, 0.20. Moderate to high phenotypic correlations between LS and the other analyzed traits were obtained, ranging from 0.50 to 0.89 , except for NBD (0.15). Moderate to low positive phenotypic correlations between $\mathrm{OR}$ and IE, LF 12 , and litter size traits were obtained. However, negative phenotypic correlations between OR and survival traits were found. Similar results for the correlation of LS with the studied traits were reported in rabbits by Blasco et al. (1993a) and Ragab and Baselga (2011). All phenotypic correlations of OR with the other traits were similar to the correlations found by Laborda et al. $(2011,2012$ a) except for LS and OR, and also for NBA and OR, where no phenotypic correlations were found, according to the response estimated using a cryopreserved control population. 
Table 3.8. Features of the marginal posterior distributions of the phenotypic correlation $\left(\boldsymbol{r}_{\boldsymbol{p}}\right)$ between litter size (LS, total number of kits born) and ovulation rate (OR), number of implanted embryos (IE), number of live foetus at 12 days of gestation $\left(\mathrm{LF}_{12}\right)$, number of kits born alive (NBA), number of kits born dead (NBD), number of kits at weaning (NW), number of rabbits at marketing (NM), embryo survival (ES), foetal survival (FS) and prenatal survival (PS).

\begin{tabular}{lcccc}
\hline Trait & $\boldsymbol{r}_{\boldsymbol{p}}$ & $\boldsymbol{P}$ & HPD95\% & $\boldsymbol{k}$ \\
\hline OR & 0.20 & 1.00 & {$[0.14,0.25]$} & 0.15 \\
IE & 0.74 & 1.00 & {$[0.72,0.77]$} & 0.72 \\
LF12 & 0.77 & 1.00 & {$[0.75,0.79]$} & 0.75 \\
NBA & 0.85 & 1.00 & {$[0.84,0.86]$} & 0.84 \\
NBD & 0.15 & 1.00 & {$[0.11,0.19]$} & 0.12 \\
NW & 0.71 & 1.00 & {$[0.69,0.72]$} & 0.69 \\
NM & 0.67 & 1.00 & {$[0.65,0.69]$} & 0.66 \\
ES & 0.69 & 1.00 & {$[0.66,0.72]$} & 0.66 \\
FS & 0.50 & 1.00 & {$[0.45,0.54]$} & 0.46 \\
PS & 0.89 & 1.00 & {$[0.88,0.90]$} & 0.88 \\
\hline $\begin{array}{l}P=\text { Probability of the phenotypic correlation being higher than zero; HPD } \\
\text { density interval at } 95 \% ; k=\text { Limit for the interval }[k,+1) \text { of the phenotypic correlation having } \\
\text { a probability of } 95 \% \text { \% }\end{array}$ & & &
\end{tabular}


Table 3.9. Features of the marginal posterior distributions of the phenotypic correlation $\left(\boldsymbol{r}_{\boldsymbol{p}}\right)$ between ovulation rate (OR) and number of implanted embryos (IE), number of live foetus at 12 days of gestation $\left(\mathrm{LF}_{12}\right)$, number of kits born alive (NBA), number of kits born dead (NBD), number of kits at weaning (NW), number of rabbits at marketing (NM), embryo survival (ES), foetal survival (FS) and prenatal survival (PS).

\begin{tabular}{lcccc}
\hline Trait & $\boldsymbol{r}_{\boldsymbol{p}}$ & $\boldsymbol{P}$ & HPD95\% & $\boldsymbol{k}$ \\
\hline IE & 0.38 & 1.00 & {$[0.33,0.42]$} & 0.34 \\
LF12 & 0.34 & 1.00 & {$[0.29,0.38]$} & 0.30 \\
NBA & 0.11 & 1.00 & {$[0.06,0.17]$} & 0.07 \\
NBD & 0.18 & 1.00 & {$[0.11,0.24]$} & 0.12 \\
NW & 0.06 & 0.97 & {$[0.00,0.12]$} & 0.01 \\
NM & 0.06 & 0.97 & {$[0.00,0.12]$} & 0.01 \\
ES & -0.12 & 1.00 & {$[-0.18,-0.07]$} & -0.08 \\
FS & -0.23 & 1.00 & {$[-0.29,-0.17]$} & -0.18 \\
PS & -0.25 & 1.00 & {$[-0.30,-0.20]$} & -0.20 \\
\hline
\end{tabular}

$P=$ Probability of the phenotypic correlation being higher than zero when the mean is positive or lower than zero when it is negative; $\mathrm{HPD}_{95 \%}=$ High posterior density interval at $95 \% ; k=$ Limit for the interval $[k,+1)$ of the phenotypic correlation having a probability of $95 \%$ when the mean is positive or limit for the interval $(-1, k]$ when it is negative. 


\subsubsection{Response to selection}

Estimated direct response to selection for LS and OR is shown in Figure 3.1 and estimated correlated responses are shown in Figure 3.2 (IE and $\mathrm{LF}_{12}$ ), Figure 3.3 (survival rates) and Figure 3.4 (NBA, NBD, NW and NM). Direct and correlated responses to selection were estimated at the end of both periods of selection as the difference between the average breeding values of last and first generation. Both periods of selection were distinguished in all figures.

\subsubsection{Selection for ovulation rate}

Selection in the first period was performed only for OR. Ovulation rate improved 0.24 ova per generation, 1.44 ova after the 6 first generations (Fig. 3.1). Similar results were obtained in pigs (by Leymaster and Christenson, 2000 and 0.26 in mice by Bradford, 1969), whereas higher response was achieved in pigs ( 0.30 by Cunningham et al.,1979 and 0.51 by Rosendo et al., 2007) and 0.67 by Land and Falconer (1969) in mice.

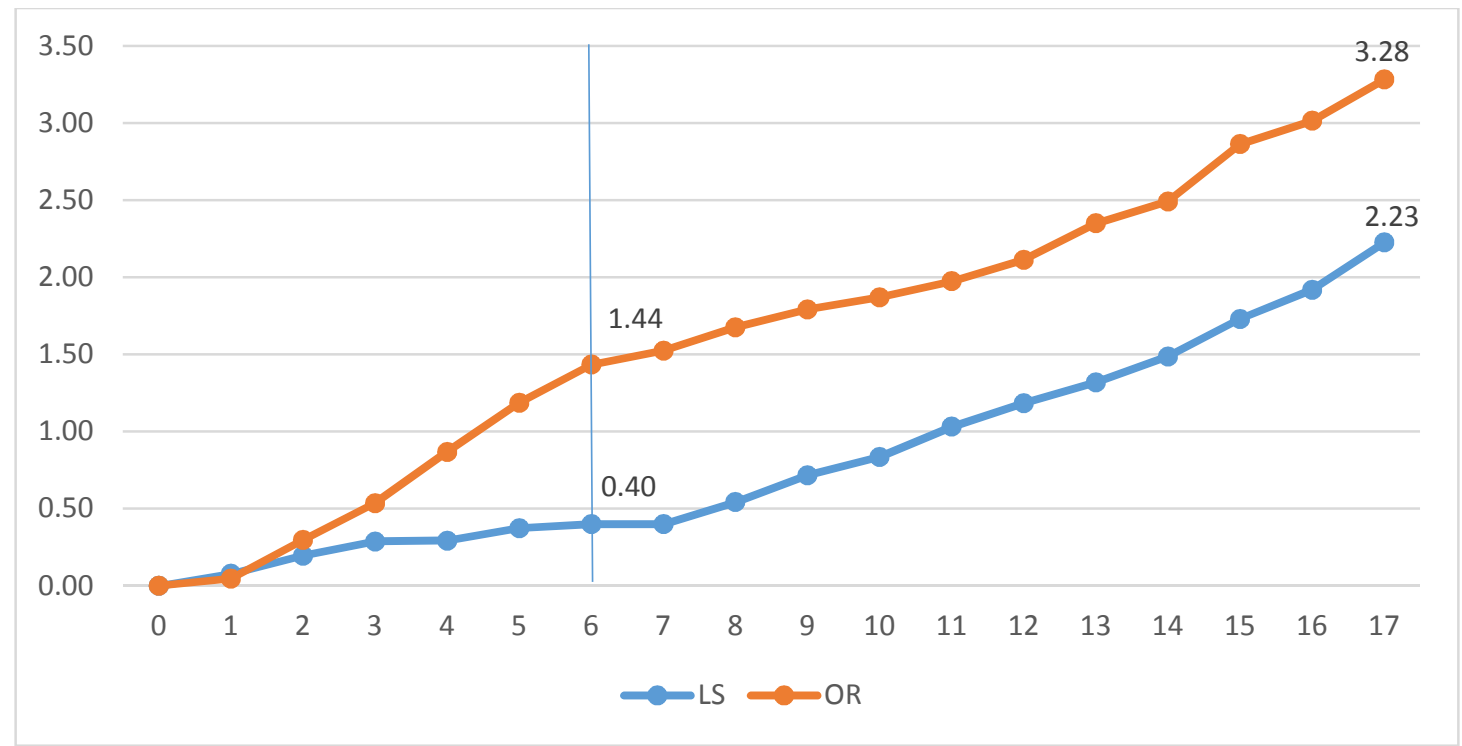

Figure 3.1. Genetic trends for ovulation rate (OR) and litter size (LS) of OR-LS line, initially selected for ovulation rate at second gestation from generation 0 to 6 and later for ovulation rate at second gestation and litter size of the first two parities from generation 7 to 17 . 
Selection for ovulation rate did not cause the expected improvement in litter size (0.07 kits per generation). Low correlated response on LS may be attributed to the limitation of uterine capacity which led to an increase on embryonic or foetal mortality when OR increases. Similar results were found for this period of selection in previous analyses published by Ziadi et al. (2013). The period of selection for OR finished without response on NBA and NBD. Similar results for LS and NBA were obtained after 6 and 9 generations of selection for OR in pigs, although all the estimations showed a low accuracy (Rosendo et al., 2007 and Cunningham et al., 1979). Correspondingly, no correlated response was observed for NW. Unexpectedly, a low correlated response on NM (0.035 kits per generation) was observed using TM program (0.21 kits after six generations). However, no correlated response for NM was obtained using VCE program (VCE, 2016). Therefore, no clear pattern about correlated response on NM was obtained after selecting OR during six generations.

Number of implanted embryos and $\mathrm{LF}_{12}$ increased 0.17 embryos and 0.15 foetus per generation, respectively (Fig. 3.2). No correlated response was observed on ES (Fig. 3.3) despite the obtained response on OR and IE. Foetal survival showed a negative genetic trend (-0.01 per generation, approximately). Prenatal survival showed a low negative response (around -0.005 per generation) as a result of decreased FS. For all survival traits, similar results were obtained in rabbits after 10 generations of selection for OR (Laborda et al., 2011 and 2012 a,b). The correlated response of PS obtained after 6 generations of selection by Rosendo et al. (2007) was also negative. 


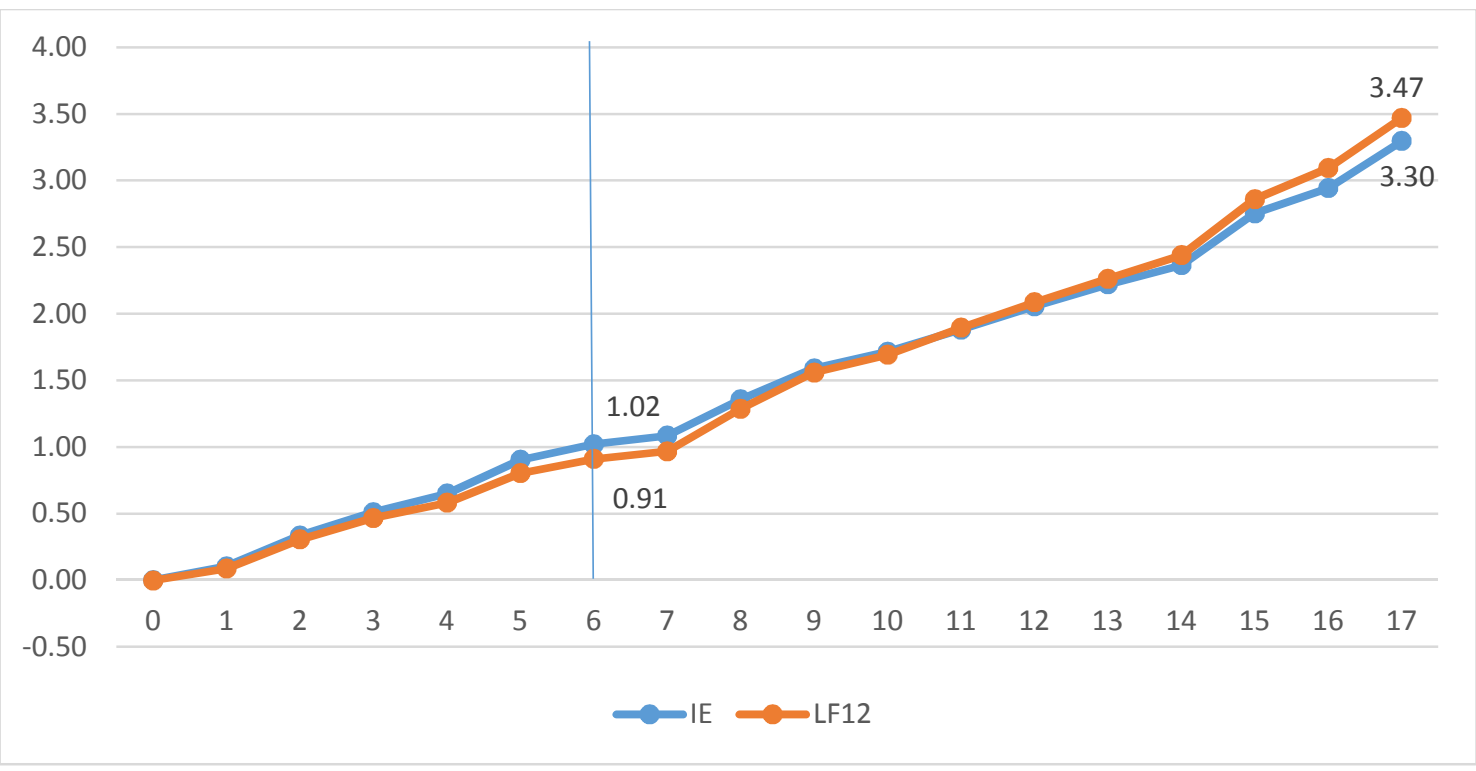

Figure 3.2. Genetic trends for number of implanted embryos (IE) and number of live fetuses at 12 days of gestation $\left(\mathrm{LF}_{12}\right)$ of OR-LS line, initially selected for ovulation rate at second gestation from generation 0 to 6 and later for ovulation rate at second gestation and litter size of the first two parities from generation 7 to 17 .

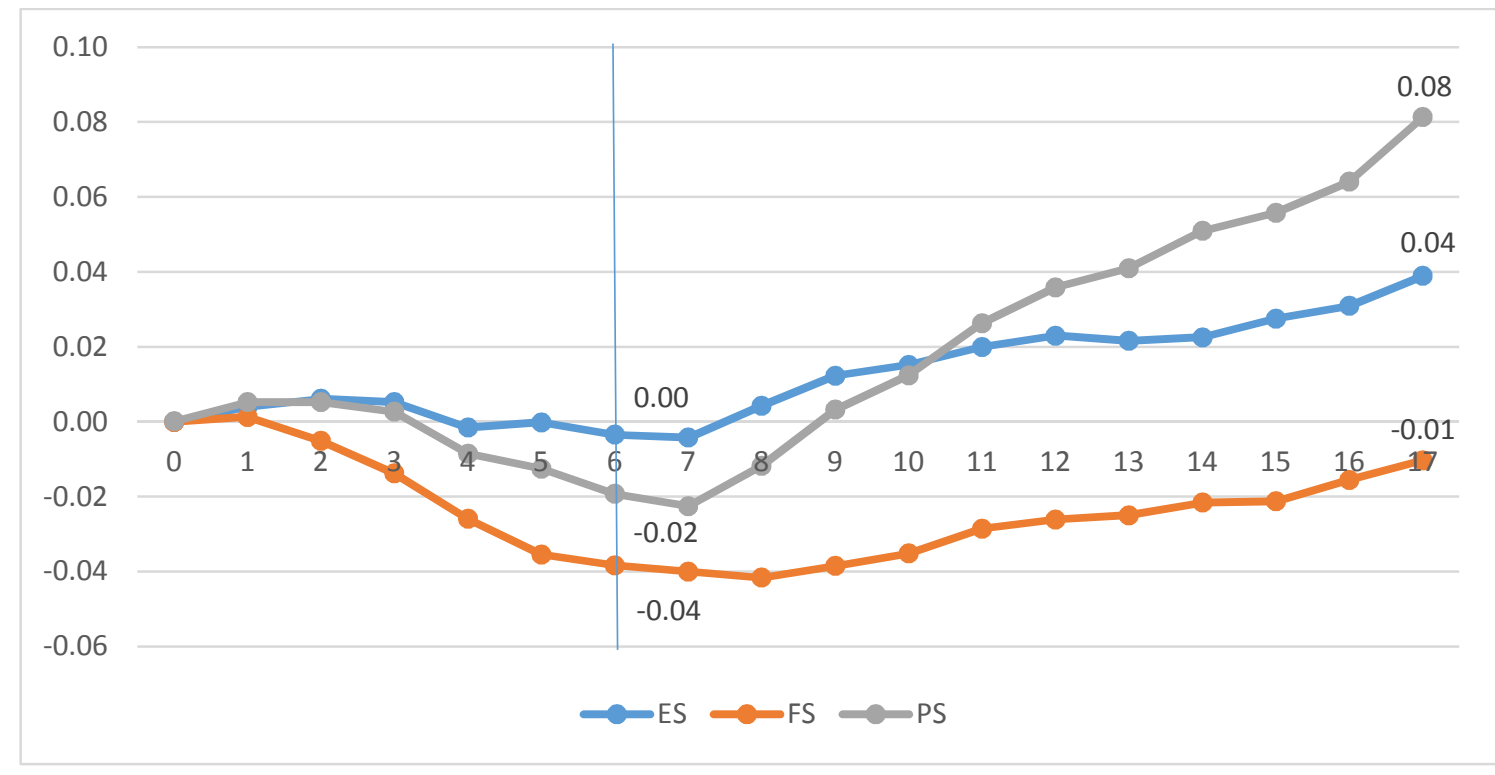

Figure 3.3. Genetic trends for embryo survival (ES), foetal survival (FS) and prenatal survival (PS) of OR-LS line, initially selected for ovulation rate at second gestation from generation 0 to 6 and later for ovulation rate at second gestation and litter size of the first two parities from generation 7 to 17 . 
Finally, results obtained in the present work, agreeing with those results obtained in other experiments of selection for ovulation rate, showed that selection for OR led to a lower response on LS than expected. This low correlated response on LS is mainly attributed to the increase in foetal mortality. Causes for foetal mortality postimplantation accompanying with the increased OR were suggested by Laborda et al. (2011); ovulation of immature oocyte, asynchrony between the foetal development and uterine environment since and increase of ovulation timing affects variability in embryonic and/or foetal development, and the competence for space and nutrients in overcrowded uterine horn.

A better knowledge of the timing of foetal mortality in females with high ovulation rate is needed to clarify the causes of foetal losses following selection for OR. Timing of mortality in females with high ovulation rate can be studied using hormones to increase OR as Van der Waaij et al. (2010) proposed. In rabbits, Badawy et al. (2016) studied the effect of $50 \mathrm{IU}$ of eCG hormone at 18 days of gestation on foetal survival and development (Chapter 5). Most of the foetal mortality appeared from 12 to 18 days of gestation; this is a critical period for foetal survival because the placenta begins controlling foetal nutrition (Adams, 1960). Hormonal treated females showed similar foetus weight to untreated. However, higher foetal placenta weight and lower variability of weights were observed in hormonal treated females than untreated females.

\subsubsection{Selection by independent culling levels for ovulation rate and litter size}

Selection for each one of litter size components separately did not increase LS more than direct selection. Thus, selection using both components as an alternative way to improve litter size was proposed (Johnson et al., 1984). Since index of selection is sensitive to the estimated genetic correlation values and these estimations had a low 
accuracy, selection by independent culling levels was proposed as an alternative to an index of selection.

During 11 generations of selection by OR and LS, the response on OR was 0.17 ova per generation (Fig. 3.1). The reduction in the selection differential can explain the decline in the response on OR during the second period compared to the first one. Correlated responses on IE and $\mathrm{LF}_{12}$ were achieved; 0.21 embryos and 0.23 foetus per generation, respectively (Fig. 3.2).

An increase in LS was observed, a total of 1.80 kits at the end of this period of selection (0.17 kits per generation; Fig. 3.1). Similar results were found by Ziadi et al. (2013) analyzing seven generations of selection. In rabbits, direct response on LS was around 0.10 kits per generation (reviews by Blasco et al. (1996) and García and Baselga, (2002a)). Therefore, selection for OR and LS could be a way to improve LS more effectively than direct selection.

Similar correlated response for NBA (0.12 kit per generation; Fig.3.4) was obtained in agreement to the high genetic correlation between LS and NBA. No correlated response for NBD was observed. The total improvement estimated during the second period of selection was 0.12 and 0.11 kits per generation for NW and NM, respectively. In pigs, Lamberson et al. (1991) observed a similar direct response on LS at birth ( 0.13 piglets per generation) using a selected line for eight generations, and previously selected for OR. Ruiz-Flores and Johnson (2001) obtained a similar response for OR $(0.27 \pm 0.07$ ova $)$, a higher response than expected for LS $(0.33 \pm 0.06$ piglets per generation) and a low correlated response on NBD $(0.11 \pm 0.03)$ after eight generations of selection by two-stage selection. 


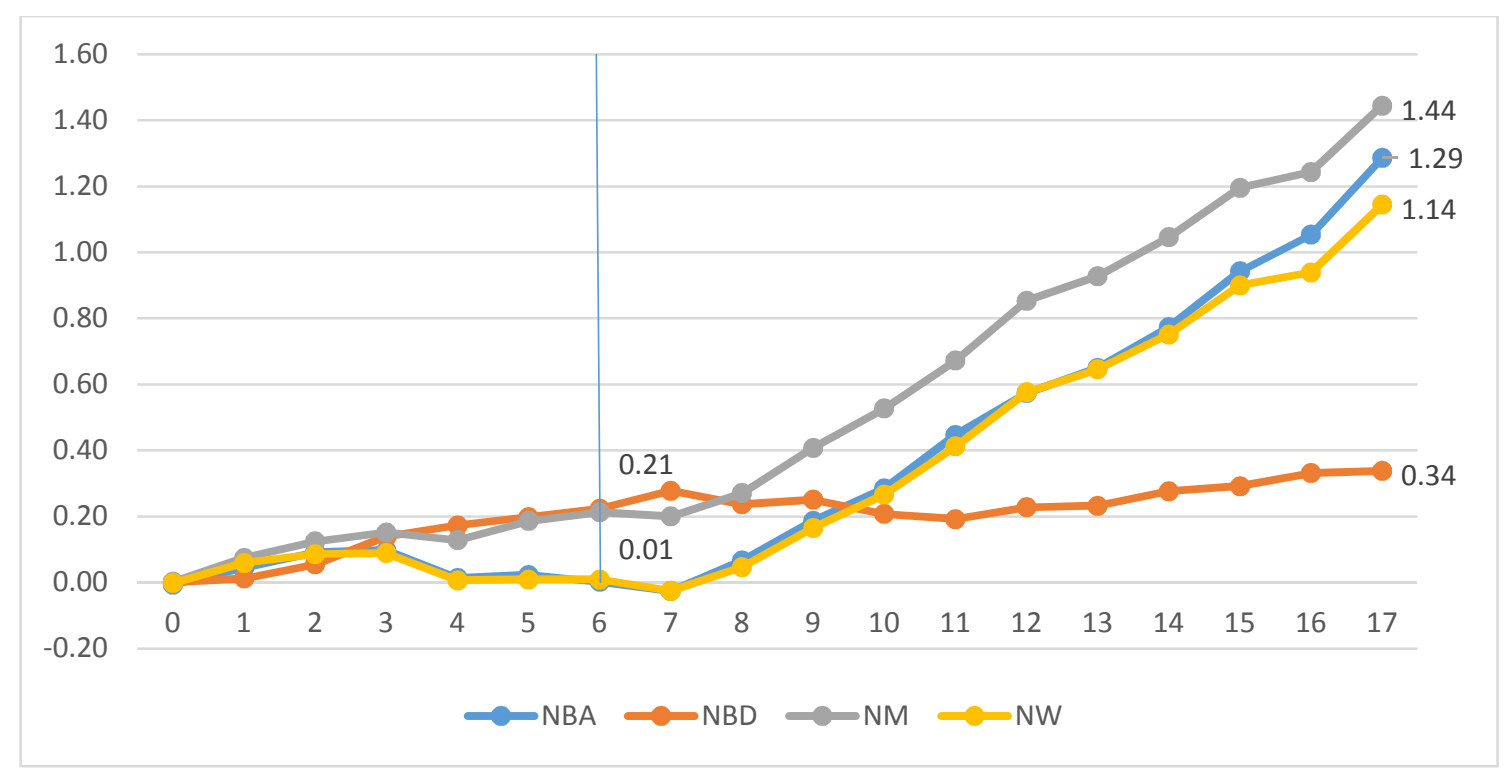

Figure 3.4. Genetic trends for number of kits born alive (NBA), number of kits born dead (NBD), number of kits at weaning (NW) and number of rabbits at marketing (NM) of OR-LS line, initially selected for ovulation rate at second gestation from generation 0 to 6 and later for ovulation rate at second gestation and litter size of the first two parities from generation 7 to 17.

Different correlated responses on survival traits were observed in the second period of selection compared to the first one. Positive correlated response on ES, FS and PS was achieved; approximately $0.005,0.003$ and 0.01 per generation, respectively (Fig. 3.3). The total increase in ES, FS and PS was 0.04, 0.03 and 0.1 in this second period of selection, respectively. Thus, the response on PS is due to the increase of survival rate in both embryo and foetal periods. This response on PS could be related to an improvement in uterine capacity. Uterine capacity is defined as the maximum number of foetus that a female can support until parturition when ovulation rate is not a limiting factor. In the present experiment, ovulation rate increased around three ova at the end of both periods of selection; therefore, a high number of females may express 
their uterine capacity and then selection for LS could improve uterine capacity by both embryo and foetal survival.

\subsection{CONCLUSION}

In conclusion, selection for OR resulted in an improvement in OR but without correlated response on LS due to the decrease in foetal survival. Selection using independent culling levels for OR and LS resulted in an improvement of both traits. The improvement in LS was achieved by an increment of OR and both ES and FS. Finally, selection for OR and LS could be more effective to improve LS than direct selection.

\subsection{REFERENCES}

Adams, C. E. (1960). Prenatal mortality in the rabbit Oryctolagus cuniculus. Journal of Reproduction and Fertility, 1: 36-44.

Argente, M. J., M. A. Santacreu, A. Climent and A. Blasco (2000). Genetic correlations between litter size and uterine capacity. In: Proceeding $7^{\text {th }}$ World Rabbit Congress, Valencia, Spain. Volume 1: 333-338.

Argente, M. J., M. A. Santacreu, A. Climent, A. Blasco and G. Bolet (1997). Divergent selection for uterine capacity in rabbits. Journal of Animal Science, 75: 23502354.

Ayyate, M. S., I. F. M. Marai and Gh. A. El-Sayiad (1995). Genetic and non-genetic factors affecting milk production and preweaning litter traits of New Zealand White does under Egyptian conditions. World Rabbit Science, 3: 119-124. 
Badawy A. Y., R. Peiró, A. Blasco and M. A. Santacreu (2016). Effect of increased ovulation rate on embryo and foetal survival as a model for selection by ovulation rate in rabbits. World Rabbit Science, 24: 87-94.

Baselga, M. (2004). Genetic improvement of meat rabbits. Programmes and diffusion. In: Proceeding $8^{\text {th }}$ World Rabbit Congress, Puebla, Mexico. Volume 1: 1-13.

Bennett, G. L., and K. A. Leymaster (1989). Integration of ovulation rate, potential embryonic viability and uterine capacity into a model of litter size in swine. Journal of Animal Science, 67: 1230-1241.

Blasco, A., J. A. Ortega, M. A. Santacreu and A. Climent (2005). Divergent selection for uterine capacity in rabbits. I. Genetic parameters and response to selection. Journal of Animal Science, 83: 2297-2302.

Blasco, A., J. P. Bidanel, G. Bolet, C. S. Haley and M. A. Santacreu (1993b). The genetics of prenatal survival of pigs and rabbits: A review. Livestock Production Science, 37: 1-21.

Blasco, A., M. A. Santacreu, R. Thompson and C. Haley (1993a). Estimates of genetic parameters for ovulation rate, prenatal survival and litter size in rabbits from an elliptical selection experiment. Livestock Production Science, 34: 163-174.

Blasco, A., P. Dando, J. Gogue and J. P. Bidanel (1996). Relationships between ovulation rate, prenatal survival and litter size in French Large White Pigs. Animal Science, 63: 143-148.

Bradford, G. E. (1969). Genetic control of ovulation rate and embryo survival in mice. I. Response to selection. Genetics, 61: 905-921.

Cartuche, L., M. Pascual, E. A. Gómez and A. Blasco (2014). Economic weights in rabbit meat production. World Rabbit Science, 22: 165-177. 
Cifre, J., M. Baselga, F. Garcia-Ximenez and J. S. Vicente (1998). Performance of hyperprolific rabbit line. I. Litter size traits. Journal of Animal Breeding and Genetics, 115: 131-138.

Clutter, A. C., M. K. Nielsen and R. K. Johnson (1990). Alternative methods of selection for litter size in mice: I. Characterization of base population and development of methods. Journal of Animal Science, 68: 3536-3542.

Cunningham, P. J., M. E. England, L. D. Young and D. R. Zimmerman (1979). Selection for ovulation rate in swine: Correlated response in litter size and weight. Journal of Animal Science, 48: 509-516.

Falconer, D. S. and T. F. C. Mackay (1996). Correlated characters. In: Introduction to quantitative genetics. Prentice Hall, Essex, England. Pages: 312-334.

Fernández, E. N. (2016). Estimación de efectos genéticos aditivos y no aditivos en líneas maternales de conejos. Tesis Doctoral. Universidad Politécnica de Valencia, Valencia, España.

García, M. L., and M. Baselga. (2002a). Estimation of genetic response to selection in litter size of rabbits using a cryopreserved control population. Livestock Production Science, 74: 45-53.

García, M. L., and M. Baselga. (2002b). Genetic response to selection for reproductive performance in a maternal line of rabbits. World Rabbit Science, 10: 71-76.

Gion, J. M., A. C. Clutter and M. K. Nielsen (1990). Alternative methods of selection for litter size in mice: II. Response to thirteen generations of selection. Journal of Animal Science, 68: 3543-3556.

Johnson, R. K., D. R. Zimmerman and R. J. Kittok (1984). Selection for components of reproduction in swine. Livestock Production Science, 11: 541-558. 
Johnson, R. K., M. K. Nielsen and D. S. Casey (1999). Responses in ovulation rate, embryonal survival and litter traits in swine to 14 generations of selection to increase litter size. Journal of Animal Science, 77: 541-557.

Kirby, Y. K. and M. K. Nielsen (1993). Alternative methods of selection for litter size in mice: III. Response to 21 generations of selection. Journal of Animal Science, 71: $571-578$.

Laborda, P., M. A. Santacreu, A. Blasco and M. L. Mocé (2012a). Selection for ovulation rate in rabbits: direct and correlated responses estimated with a cryopreserved control population. Journal of Animal Science, 90: 3392-3397.

Laborda, P., M. L. Mocé, A. Blasco and M. A. Santacreu (2012b). Selection for ovulation rate in rabbits: genetic parameters and correlated responses on survival rates. Journal of Animal Science, 90: 439-446.

Laborda, P., M. L. Mocé, M. A. Santacreu and A. Blasco (2011). Selection for ovulation rate in rabbits: I. genetic parameters, direct response and correlated response on litter size. Journal of Animal Science, 89: 2981-2987.

Lamberson, W. R., R. K. Johnson, D. R. Zimmerman and T. E. Long (1991). Direct response to selection for increased litter size, decreased age at puberty, or random selection following selection for ovulation rate in swine. Journal of Animal Science, 69: 3129-3143.

Land, R. D. and D. S. Falconer (1969). Genetic studies of ovulation rate in the mouse. Genetical Research, 13: 25-46.

Legarra, A., L. Varona and E. López de Maturana (2008). Program TM. http://snp.toulouse.inra. fr/ alegarra/ 
Leymaster, K. A. and R. K. Christenson (2000). Direct and correlated responses to selection for ovulation rate or uterine capacity in swine. Journal of Animal Science, 78 (Suppl.1): 68.

Lukefahr, S. D. and H. H. Hamilton (1997). Heritability and repeatability estimates of maternal performance traits in purebred and crossbred does. World Rabbit Science 3: 99-105.

Nagy, I., G. Gorjanc, I. Curik, J. Farkas, H. Kiszlinger and Zs. Szendrö (2013). The contribution of dominance and inbreeding depression in estimating variance components for litter size in Pannon White rabbits. Journal of Animal Breeding and Genetics, 130: 303-311.

Piles, M., M. L. Garcia, O. Rafel, J. Ramon and M. Baselga (2006). Genetics of litter size in three maternal lines of rabbits: Repeatability versus multiple-trait models. Journal of Animal Science, 84: 2309-2315.

Ragab, M. (2012). Genetic analyses of reproductive traits in maternal lines of rabbits and in their diallel cross. Tesis Doctoral. Universidad Politécnica de Valencia, Valencia, España.

Ragab, M. and M. Baselga (2011) A comparison of reproductive traits of four maternal lines of rabbits selected for litter size at weaning and founded on different criteria. Livestock Science, 136: 201-206.

Rochambeau, H. de, G. Bolet and F. Tudela (1994). Long term selection. Comparison of two rabbit strains. In: Proceeding $5^{\text {th }}$ World Congress on Genetics Applied to Livestock Production, Guelph, Canada. Volume 19: 257-260. 
Rosendo, A. T., T. Druet, J. Gogué and J. P. Bidanel (2007). Direct responses to six generations of selection for ovulation rate or prenatal survival in Large White pigs. Journal of Animal Science, 85: 356-364.

Ruiz-Flores, A. and R. K. Johnson (2001). Direct and correlated responses to two-stage selection for ovulation rate and number of fully formed pigs at birth in swine. Journal of Animal Science, 79: 2286-2299.

Santacreu, M. A., M. L. Mocé, A. Climent and A. Blasco (2005). Divergent selection for uterine capacity in rabbits. II. Correlated response in litter size and its components estimated with a cryopreserved control population. Journal of Animal Science, 83: 2303-2307.

Santacreu, M. A., P. Viudes and A. Blasco (1990). Evaluation par coelioscopie des corps jaunes et des embryons. Influence sur la taille de portée chez la lapine. Reproduction Nutrition Development, 30: 583-588.

Sorensen, D. and D. Gianola (2002). Likelihood, Bayesian, and MCMC methods in quantitative genetics. Springer-Verlag, New York, United States.

Van der Waaij, E. H., W. Hazeleger, N. M. Soede, B. F. A. Laurenssen and B. Kemp (2010). Effect of excessive, hormonally induced intrauterine crowding in the gilt on fetal development on d 40 of pregnancy. Journal of Animal Science, 88: 26112619.

VCE (2016). Variance Component Estimation software. https://vce.tzv.fal.de

Ziadi, C., M. L. Mocé, P. Laborda, A. Blasco and M. A. Santacreu (2013). Genetic selection for ovulation rate and litter size in rabbits: Estimation of genetic parameters and direct and correlated responses. Journal of Animal Science, 91: $3113-3120$ 



\section{CHAPTER FOUR}





\section{CHAPTER 4}

Selection for Ovulation Rate and Litter Size Using Independent Levels in Rabbits:

Genetic Parameters and Correlated Responses on Growth Traits

Acknowledgements: This study was supported by the Comisión Interministerial de Ciencia y Tecnología CICYT-AGL2011-29831-C03-01 and by funds from Generalitat Valenciana research programme (Prometeo 2009/125). A.Y. Badawy was supported by a grant of the Egyptian Ministry of Higher Education. 



\subsection{ABSTRACT}

The objective of this study was to evaluate the effect of selection for ovulation rate and litter size on growth traits in rabbit through estimation of genetic parameters and genetic response. The experiment involved two selection periods. In the first one, selection was performed for ovulation rate, recorded by laparoscopy at day 12 of second gestation. In the second one, selection was performed for ovulation rate and litter size using independent culling levels. Each generation consisted of about 75 females and 17 males, and the total selection pressure was around $30 \%$. The measured traits were ovulation rate (OR), litter size (LS), weaning weight (WW), marketing weight (MW) and growth rate during fattening period (GR). Data was analysed using Bayesian inference methods. Heritability estimates were low for LS (0.10) and growth traits $(0.09,0.13$ and 0.14 , for WW, MW and GR, respectively) and moderate for OR (0.25). Low environmental maternal effect for WW, MW and GR was obtained $(0.11,0.05$ and 0.01, respectively). Moderate environmental common litter effect was observed and also it decreased as the maternal one; 0.35 and 0.28 for WW and MW, respectively. Null genetic correlations were observed between LS and growth traits, whereas positive and low or moderate genetic correlations were observed between OR and growth traits. Positive correlated response in both periods were obtained for growth traits; WW, MW and GR. The positive moderate genetic correlation estimated between OR and MW could explain the correlated response found in MW. Correlated response on WW could be explained by positive and high genetic correlation between MW and WW.

Keywords: selection, litter size, ovulation rate, weaning weight, marketing weight, growth rate, genetic response. 


\subsection{INTRODUCTION}

The main objective of rabbit genetic improvement programs is to increase the production of rabbit for slaughter at a lower cost (Cartuche et al., 2014). Three lines, two maternal and one paternal lines are usually involved in rabbit genetic improvement programs. Maternal lines are selected for litter size at birth or at weaning and they are crossed in order to produce a hybrid commercial doe (Ragab and Baselga, 2011), while paternal line is selected for post-weaning daily gain (Rochambeau, 1988; Baselga, 2004). Crosses between hybrid females and males from a paternal line are performed to produce rabbit meat, depending on the higher reproductive performance of maternal lines and growth performance of paternal line. Since commercial progeny received 50 $\%$ of the genetic material from maternal lines, therefore these lines should show a proper level of growth performance.

There are very few estimates of genetic correlations between litter size and growth traits. Available information is varied depending on the population or breed. Studies do not show any clear pattern but generally estimated correlations are low and with a high standard error (Mocé and Santacreu, 2010). After 21 generations of selection for litter size at 28 days of age, García and Baselga (2002 a,b) reported no correlated response on weaning and marketing weight and growth rate using genetic trends and a cryopreserved control population. However, Brun and Ouhayoun (1994) observed lower weaning (at 30 days) and marketing (79 days) weights (-56 \pm 11 and $100 \pm 23$ grams, respectively) in a line selected for litter size at weaning (A1077) than the control one after 13 generations of selection, corresponding to 4.31 and 7.69 grams per generation, respectively. In agreement with these results, Rochambeau (1998) reported that the individual weight at weaning (at 30 days) decreased after 18 
generations of selection for litter size in lines A1077 and A2026 (-3.4 and -4.4 grams per generation, respectively).

Little is known about the relationship between components of litter size (ovulation rate and survival rates) and growth traits. Low positive genetic correlations between ovulation rate and growth traits were found after a selection experiment for ovulation rate during 10 generations (Quirino et al., 2009). The estimations ranged from 0.11 (for correlation with weaning weight) to 0.28 (for correlation with growth rate), although they had a low accuracy. Similar results for weaning weight were reported by Young et al. (1974) and by Rosendo et al. (2007) in pigs.

The aim of this study is to estimate the correlated response to selection for ovulation rate and litter size in weaning weight (28 days), marketing weight (63 days) and growth rate during the fattening period (from 28 to 63 days).

\subsection{MATERIALS AND METHODS}

All experimental procedures involving animals were approved by the Universitat Politècnica de València Research Ethics Committee.

\subsubsection{Animals and experimental design}

Animals involved in this study came from a line (OR-LS) whose origin was a synthetic line (V line) first selected for litter size at weaning (28 days) for 12 generations (García and Baselga, 2002a), then for high uterine capacity for 10 generations (Blasco et al., 2005), and then selection was relaxed for 6 generations. From there, founders were chosen at random within families to create the line OR-LS.

Line OR-LS underwent 17 generations of selection. From base generation to generation 6 (first selection period), females were selected only for ovulation rate at second gestation estimated by laparoscopy. From generation 7 to 17 (second selection 
period), a 2-stage selection for ovulation rate and litter size was performed. In stage 1, females having the highest ovulation rate at second gestation were selected. In stage 2, selection was for the highest average litter size of the first two parities of those females selected in stage 1 . There were no generations of relaxed selection between these two periods of selection. Until the generation six, selection pressure in females was about $30 \%$. From generation 7 to 17, selection pressure was about 65 and $50 \%$ for ovulation rate and litter size, respectively. Males were selected within families from litters of best dams. The number of females and males was around 75 and 17 per generation, respectively.

Does were mated for the first time at 18 to 20 weeks of age and 11 to 12 days after each parturition. Females that did not accept males were mated again one week afterward. Pregnancy was checked approximately 12 days after mating by abdominal palpation.

Adult animals were housed at the farm of the Universitat Politècnica de Valencia in individual cages (flat-deck) having extractable nest box with isolated plastic. Kits were housed in dam's cages up to the weaning (28 days) and then were placed in flat-deck cages to 63 days of age (eight-nine rabbits per cage). At 63 days, rabbits were placed in individual flat-deck cages until 18 to 20 weeks of age. During fattening period, rabbits were fed ad libitum with a commercial diet (crude protein, 15.0 $\%$; crude fiber, $16.8 \%$; crude fat, $2.4 \%$; ash, $7.3 \%$ as fed basis; NANTA, S.A. ${ }^{\circledR}$, Valencia, Spain). From 63 days of age, rabbits were fed with a commercial diet (crude protein, $16.5 \%$; crude fiber, $15.0 \%$; crude fat, $3.0 \%$; ash, $7.8 \%$ as fed basis; NANTA, S.A. ${ }^{\circledR}$ ). Animals were reared under a photoperiod of 16-hours light: 8-hours dark and controlled temperature and ventilation. 


\subsubsection{Traits}

Weaning (WW, kg) and marketing weight (MW, $\mathrm{kg}$ ) were estimated individually for each animal at 28 and 63 days of age, respectively. Growth rate (GR, kg) was estimated as the difference between both weights, (MW-WW).

Litter size (LS) was measured as the total number of kits born per litter up to five parities. Ovulation rate (OR), estimated as the number of corpora lutea in both ovaries, was measured by laparoscopy at day 12 of the second and post-mortem in the last gestation (from $3^{\text {rd }}$ to $6^{\text {th }}$ gestation).

Number of records for weaning weight (WW), marketing weight (MW) and growth rate (GR) were 30,420; 29,075 and 29,057, respectively (Table 4.1). These data came from 1317 dams with 4027 litters. Moreover, data from 1,210 laparoscopies and 4,480 parities were analysed. The number of animals in the pedigree was 30,666.

\subsubsection{Statistical Analysis}

Data from all 17 generations of selection were used in the analysis. Bayesian inference methods were used. Trivariate animal models were fitted to estimate the genetic parameters and genetic responses. Each trivariate analysis included LS, OR and one of each growth traits (WW, MW or GR).

The model used for analysed the data of OR and LS assumed to be:

$$
y_{i j k l}=Y S_{i}+P H Y S_{j}+a_{k}+p_{k}+e_{i j k l}
$$

in which, $y_{i j k l}$ is the record of the trait, $Y S_{i}$ is the effect of year season (three months per each year season; 49 and 44 levels for LS and OR, respectively), $P H Y S_{j}$ is the effect of physiological status at mating (five levels for litter size traits; nulliparous, lactating primiparous, non-lactating primiparous, lactating multiparous and non-lactating multiparous; the latest four levels for OR), $a_{k}$ is the additive value of the animal $\mathrm{k}, p_{k}$ is 
the permanent environmental non-additive effect of the female $\mathrm{k}$, and $e_{i j k l}$ is the residual of the model.

The model used for analysed the data of WW, MW and GR was:

$$
y_{i j k l m}=b \times N B A+Y S_{i}+P O_{j}+a_{k}+m_{l}+l i_{m}+e_{i j k l m}
$$

in which, $y_{i j k l m}$ is the record of the trait of animal $k$; NBA is the number of kits born alive in which the animal $k$ was born and $b$ is the regression coefficient on NBA (considering the effect of the litter size where rabbit is born); $Y S_{i}$ is the effect of year season (three months per each year season; 46 levels); $P O_{j}$ is the effect of the parity order in which the animal was born $\left(4\right.$ levels: $1^{\text {st }}, 2^{\text {nd }}, 3^{\text {rd }}$ and $\left.>3^{\text {th }}\right) ; a_{k}$ is the random additive value of animal $k ; m_{l}$ is the environmental random effect of the over all the parities of the dam of the animal $k$; $l i_{m}$ is the random effect of the common litter in which the animal $k$ was born; and $e_{i j k l m}$ is the residual effect.

The correlation structure between the random effects in the two models was established between the additive effects of the three traits; between the environmental maternal effect of growth traits $\left(m_{l}\right)$ and the permanent environmental effect of the doe on LS and OR $\left(p_{k}\right)$. Also, for the environmental covariance structure between each growth trait and reproductive traits, the term $e_{j k l}$, of LS and OR was divided into two parts, $c_{j k l}$ and $e^{*}{ }_{j k l}$, the first was assumed to be correlated with the litter of origin effect in the growth trait model $\left(l i_{m}\right)$ and the second was uncorrelated to any other term of the model fitting the growth trait (García and Baselga, 2002b; Mínguez et al., 2016).

The joint prior distribution assumed for additive genetic effects was $N(\mathbf{0}, \mathbf{G a} \otimes \mathbf{A})$, where $\mathbf{G}_{\mathbf{a}}$ was the genetic (co)variance matrix between the traits and $\mathbf{A}$ was the additive genetic relationship matrix. The prior distribution for the permanent environmental effect of the doe $\left(p_{k}\right)$ and the maternal effect of growth trait $\left(m_{l}\right)$ was $N\left(\mathbf{0}, \mathbf{G}_{\mathbf{p}} \otimes \boldsymbol{I}\right)$, where $\mathbf{G}_{\mathbf{p}}$ was the (co)variance matrix between these effects. The joint prior distribution for 
the litter of origin effect $\left(l i_{m}\right)$ in the growth trait and the term $c_{j k l}$ was $N\left(\mathbf{0}, \mathbf{G}_{\mathbf{l i}} \otimes \boldsymbol{I}\right)$, where $G_{l i}$ was the (co)variance matrix between these litter effects. The residual prior distribution was $N\left(\mathbf{0}, \mathbf{I} \sigma_{e^{*}}^{2}\right)$ for the LS and OR model and $N\left(\mathbf{0}, \mathbf{I} \sigma_{e}^{2}\right)$ for the growth traits model. The order of the identity matrix I was equal to the number of records measured in each case. Bounded uniform priors were used for the components of the (co)variance matrices.

Marginal posterior distributions of all unknowns were estimated by using the Gibbs sampling algorithm. The data vector was augmented to have the same design matrices for all traits. Augmented data were not used for inferences but simplified computing by sampling from a predictive distribution of missing data (Sorensen and Gianola, 2002). The program TM developed by Legarra et al. (2008) was used for all Gibbs sampling procedures. After some exploratory analyses, chains of 3,000,000 samples were used, with a burn in period of 750,000. One sample each 100 were saved to avoid high correlations between consecutive samples. Convergence was tested using the $\mathrm{Z}$ criterion of Geweke (Sorensen and Gianola, 2002).

\subsection{RESULTS AND DISCUSSION}

Means, standard deviations (SD) and coefficient of variation (CV) for growth traits are shown in Table 4.1. Values were similar to those presented by García and Baselga (2002b) in V line selected for number of kits at weaning, whose obtained 488 \pm 11 and $1831 \pm 23$ grams for weights at weaning and marketing, respectively. The growth rate during fattening period was $37.9 \pm 0.60$ grams per day. Mínguez et al. (2016), analysing a large set of data from four maternal lines, where V line was included, obtained an overall mean of $0.57 \pm 0.13 \mathrm{~kg}, 1.86 \pm 0.26 \mathrm{~kg}$ and $36.70 \pm 5.70$ grams per day for weaning and marketing weights and growth rate, respectively. In a 
line selected for ovulation rate during 10 generations, Quirino et al. (2009) reported

$0.52,1.76$ and $1.24 \mathrm{~kg}$ for weaning weight, marketing weight and growth rate.

Table 4.1. Descriptive statistics for weaning weight (WW, kg), marketing weight (MW, $\mathrm{kg}$ ) and growth rate (GR, $\mathrm{kg}$ ) after selection for six generations for ovulation rate and 11 generations for ovulation rate and litter size.

\begin{tabular}{lcccc}
\hline \multicolumn{1}{c}{ Trait } & N & Mean & SD & CV (\%) \\
\hline WW & 30,420 & 0.50 & 0.12 & 23.94 \\
MW & 29,075 & 1.74 & 0.24 & 13.75 \\
GR & 29,057 & 1.24 & 0.17 & 13.69 \\
\hline
\end{tabular}

$\mathrm{N}=$ Number of records, $\mathrm{SD}=$ Standard deviation, $\mathrm{CV}=$ Coefficient of variation.

\subsubsection{Genetic parameters}

In all analyses, mean and median were similar for all traits, because the marginal posterior distributions were symmetric. Monte Carlo standard errors were small; no lack of convergence was detected by Geweke test.

\subsubsection{Heritability}

Features of the marginal posterior distributions of the heritability are shown in Table 4.2.

Table 4.2. Features of marginal posterior distributions of the heritability $\left(h^{2}\right)$ of weaning weight (WW), marketing weight (MW) and growth rate (GR) during fattening period.

\begin{tabular}{lccccc}
\hline \multicolumn{1}{c}{ Trait } & $\boldsymbol{h}^{\mathbf{2}}$ & SD & $\boldsymbol{P}_{\text {0.10 }}$ & HPD95\% & $\boldsymbol{k}$ \\
\hline WW & 0.09 & 0.02 & 0.22 & {$[0.05,0.12]$} & 0.06 \\
MW & 0.13 & 0.02 & 0.92 & {$[0.09,0.17]$} & 0.09 \\
GR & 0.14 & 0.02 & 0.97 & {$[0.10,0.18]$} & 0.10
\end{tabular}

$\mathrm{SD}=$ Standard deviation; $P_{0.10}=$ Probability of the heritability being higher than $0.10 ; \mathrm{HPD}_{95 \%}=$ High posterior density interval at $95 \% ; k=$ Limit for the interval $[k,+1)$ of the heritability having a probability of $95 \%$. 
Heritability estimates for growth traits were low, $0.09\left[\mathrm{HPD}_{95 \%}=0.05,0.12\right]$ for WW, 0.13 for MW $\left[\mathrm{HPD}_{95 \%}=0.09,0.17\right]$ and 0.14 for $\mathrm{GR}\left[\mathrm{HPD}_{95 \%}=0.10,0.18\right]$. The probability that the heritability was higher than 0.10 was close to $95 \%$ for MW and GR. Similar estimates and accuracies were observed in a line selected for ovulation during 10 generations (Quirino et al., 2009; 0.09, 0.12 and 0.11 for WW, MW and GR, respectively). Mínguez et al. (2016), using data from four maternal lines, where V line was included, obtained similar heritability for WW. Higher estimated heritability was found for MW and GR; 0.19 and 0.21, respectively. García and Baselga (2002b), using a similar model, reported higher heritability values for growth traits after selection for litter size at weaning during 21 generations in $\mathrm{V}$ line. These values were $0.22 \pm 0.01$, $0.30 \pm 0.01$ and $0.20 \pm 0.01$ for WW, MW and GR, respectively. Low to moderate heretabilities for growth traits were obtained by Gómez et al. (2000) using a line selected for litter weight at 60 days $(\mathrm{WW}=0.14 \pm 0.014 ; \mathrm{MW}=0.23 \pm 0.015 ; \mathrm{GR}=0.27$ $\pm 0.016)$. Different heritabilities could be due to estimation methods, variability of the lines at foundation, environmental effects or sampling errors due to the small number of data used.

\subsubsection{Maternal effect $\left(m^{2}\right)$ and common litter effect $\left(c^{2}\right)$}

Features of marginal posterior distributions of proportion of the maternal effect variance respect to their phenotypic variances $\left(\mathrm{m}^{2}\right)$ for growth traits are shown in Table (4.3). High accuracy of these effects was obtained for all traits. Estimate of maternal effect in WW was low, 0.11, and higher than those obtained for MW and GR. These results showed the environmental effect of dam decreases with the advance in age. Similar estimates were obtained by Mínguez et al. (2016) in four maternal lines selected for number of kits at weaning $(0.11 \pm 0.004,0.04 \pm 0.003$ and $0.003 \pm 0.001$ for $\mathrm{WW}$, MW and GR, respectively). However, higher estimations were reported by García and 
Baselga (2002b) for WW, MW and GR $(0.18 \pm 0.004,0.21 \pm 0.007$ and $0.26 \pm 0.005$, respectively) in $\mathrm{V}$ line.

Table 4.3. Features of marginal posterior distributions of proportion of the maternal effect variance $\left(\mathrm{m}^{2}\right)$ respect to phenotypic variance for weaning weight (WW), marketing weight (MW) and growth rate (GR).

\begin{tabular}{lcccc}
\hline \multicolumn{1}{c}{ Trait } & $\boldsymbol{m}^{\mathbf{2}}$ & SD & HPD95\% & $\boldsymbol{k}$ \\
\hline WW & 0.11 & 0.01 & {$[0.09,0.13]$} & 0.09 \\
MW & 0.05 & 0.01 & {$[0.03,0.06]$} & 0.03 \\
GR & 0.01 & 0.00 & {$[0.00,0.02]$} & 0.00 \\
\hline
\end{tabular}

$\mathrm{SD}=$ Standard deviation; $\mathrm{HPD}_{95 \%}=$ High posterior density interval at $95 \% ; k=$ Limit for the interval $[k,+1)$ of the maternal effect variance respect to phenotypic variance having a probability of $95 \%$.

The environmental effect of common litter expresses the part of variance due to shared prenatal effects among embryos/foetus of the same gestation, like oviductal and uterine environment. Common litter effect also includes postnatal environment among kits of the same litter, like milk production, maternal behaviour and the non-lineal effects of litter size in which each kit was born. Features of the marginal posterior distributions of the environmental effect of common litter for growth traits are shown in Table (4.4). Estimated values for $c^{2}$ obtained in the present study were moderate for all growth traits and they were at least 0.34 for WW and 0.26 for both MW and GR with a probability of $95 \%$. Similar to maternal effects, the common litter effect decreased from WW to MW. Similar results were observed by Mínguez et al. (2016) in four maternal lines $(0.36 \pm 0.003,0.26 \pm 0.003$ and $0.29 \pm 0.003)$ and Garcia and Baselga (2002b) in V line $(0.42 \pm 0.01,0.28 \pm 0.01$ and $0.29 \pm 0.00)$ for $W W$, MW and GR, respectively. Similar effects for WW and GR were estimated by Mcnitt and Lukefahr (1996; 0.50 and 0.31, respectively). The high estimation of environmental common litter effect may express the important influence of pre-weaning environment 
on growth at least until marketing. The short fattening could explain the importance of maternal and litter effects on MW and GR.

Table 4.4. Features of marginal posterior distributions of the proportion of the common litter effect variance $\left(c^{2}\right)$ respect to phenotypic variance for weaning weight (WW), marketing weight (MW) and growth rate (GR).

\begin{tabular}{lcccc}
\hline \multicolumn{1}{c}{ Trait } & $\boldsymbol{c}^{2}$ & SD & HPD95\% & $\boldsymbol{k}$ \\
\hline WW & 0.35 & 0.01 & {$[0.33,0.37]$} & 0.34 \\
MW & 0.28 & 0.01 & {$[0.26,0.30]$} & 0.26 \\
GR & 0.27 & 0.01 & {$[0.25,0.29]$} & 0.26 \\
\hline
\end{tabular}

$\mathrm{SD}=$ Standard deviation; $\mathrm{HPD}_{95 \%}=$ High posterior density interval at $95 \% ; k=$ Limit for the interval $[k,+1)$ of the common litter effect variance respect to phenotypic variance having a probability of $95 \%$.

\subsubsection{Correlations between reproductive traits and growth traits}

Features of the marginal posterior distributions of the genetic correlation between studied traits are shown in Table (4.5). All genetic correlation values were estimated with a high posterior density interval at probability at $95 \%$. Null genetic correlations were observed between LS and growth traits, since values were close to zero $(P$ lower than 0.80 for all correlations). These results were in agreement with those found by García and Baselga (2002b) in the V line. However, Mínguez et al. (2016) reported a positive moderate correlation between litter size at weaning and WW (0.30) and low correlations between litter size at weaning and both MW and GR using four maternal lines selected for number of kits at weaning.

Positive genetic correlations were found between OR and growth traits, low for WW $(0.19 ; P=0.92)$ and moderate for MW and GR $(0.38$ and 0.36 , respectively; $P=1.00$ for both traits). Little is known about the genetic relationship between OR and weight traits. Quirino et al. (2009) reported also positive genetic correlations for these traits, with low accuracy, in a line selected for ovulation rate during 10 generations. In pigs, 
positive genetic correlations were reported between OR and average daily gain $(0.20 \pm$ 0.06) by Bidanel et al. (1996) and between OR and weaning weight $(0.11 \pm 0.12)$ by Rosendo et al. (2007). No genetic correlation was found between OR and GR from weaning to performance $(0.03 \pm 0.11)$ by these authors.

Little information is available about correlations between permanent effects of reproductive and growth traits. Features of the marginal posterior distributions of these correlations are shown in Table (4.6). Estimated correlations were positive and high between LS and growth traits (from 0.72 to 0.89 ), whereas positive and moderate correlations were obtained between OR and growth traits (from 0.45 to 0.55 ). Higher correlations were expected for LS vs OR because it was closer in time with growth traits.

Table 4.5. Features of marginal posterior distributions of the genetic correlation $\left(r_{g}\right)$ of litter size (LS) and ovulation rate (OR) with weaning weight (WW), marketing weight (MW) and growth rate (GR).

\begin{tabular}{lccccc}
\hline \multicolumn{1}{c}{ Trait } & $\boldsymbol{r}_{\boldsymbol{g}}$ & SD & $\boldsymbol{P}$ & HPD95\% & $\boldsymbol{k}$ \\
\hline LS, WW & -0.11 & 0.17 & 0.73 & {$[-0.43,0.23]$} & 0.17 \\
LS, MW & 0.03 & 0.15 & 0.58 & {$[-0.27,0.34]$} & -0.21 \\
LS, GR & 0.11 & 0.16 & 0.76 & {$[-0.18,0.42]$} & -0.14 \\
\hline OR, WW & 0.19 & 0.13 & 0.92 & {$[-0.07,0.45]$} & -0.03 \\
OR, MW & 0.38 & 0.11 & 1.00 & {$[0.16,0.60]$} & 0.19 \\
OR, GR & 0.36 & 0.11 & 1.00 & {$[0.14,0.58]$} & 0.17 \\
\hline
\end{tabular}

$\mathrm{SD}=$ Standard deviation; $P=$ Probability of the genetic correlation being higher than zero when the mean is positive or lower than zero when it is negative; $\mathrm{HPD}_{95 \%}=$ High posterior density interval at $95 \% ; k=$ Limit for the interval $[k,+1)$ of the genetic correlation having a probability of $95 \%$ when the mean is positive or limit for the interval $(-1, k]$ when it is negative. 
Table 4.6. Features of the marginal posterior distributions of the correlation between permanent effects $\left(r_{\text {permanent }}\right)$ for litter size (LS) and ovulation rate (OR) with weaning weigh (WW), marketing weight (MW) and growth rate (GR).

\begin{tabular}{lccccc}
\hline \multirow{2}{*}{ Trait } & \multicolumn{2}{c}{$\boldsymbol{r}_{\text {permanent }}$} & \multirow{P}{*}{ HPD95\% } & $\boldsymbol{k}$ \\
\cline { 2 - 3 } & Mean & SD & & & \\
\hline LS, WW & 0.89 & 0.14 & 1.00 & {$[0.59,1.00]$} & 0.59 \\
LS, MW & 0.83 & 0.23 & 0.99 & {$[0.35,1.00]$} & 0.35 \\
LS, GR & 0.72 & 0.50 & 0.94 & {$[-0.06,1.00]$} & -0.06 \\
\hline OR, WW & 0.45 & 0.33 & 0.88 & {$[-0.18,0.99]$} & -0.18 \\
OR, MW & 0.55 & 0.30 & 0.95 & {$[-0.03,1.00]$} & -0.03 \\
OR, GR & 0.52 & 0.36 & 0.91 & {$[-0.13,0.98]$} & -0.13 \\
\hline
\end{tabular}

$\mathrm{SD}=$ Standard deviation; $P=$ Probability of the correlation between permanent effects being higher than zero; $\mathrm{HPD}_{95 \%}=$ High posterior density interval at $95 \% ; k=$ Limit for the interval $[k$, +1 ) of the correlation between permanent effects having a probability of $95 \%$.

Table 4.7. Features of marginal posterior distributions of the phenotypic correlation $\left(r_{p}\right)$ of litter size (LS) and ovulation rate (OR) with weaning weight (WW), marketing weight (MW) and growth rate (GR).

\begin{tabular}{lcccc}
\hline \multicolumn{1}{c}{ Trait } & $\boldsymbol{r}_{\boldsymbol{p}}$ & $\boldsymbol{P}$ & HPD95\% & $\boldsymbol{k}$ \\
\hline LS, WW & 0.02 & 0.76 & {$[-0.04,0.09]$} & -0.03 \\
LS, MW & 0.07 & 0.93 & {$[-0.03,0.16]$} & -0.01 \\
LS, GR & 0.09 & 0.94 & {$[-0.02,0.19]$} & -0.00 \\
\hline OR, WW & 0.29 & 0.98 & {$[0.04,0.50]$} & 0.06 \\
OR, MW & 0.33 & 0.97 & {$[0.04,0.58]$} & 0.06 \\
OR, GR & 0.30 & 0.95 & {$[-0.02,0.57]$} & 0.00
\end{tabular}

$P=$ Probability of the phenotypic correlation being higher than zero; $\mathrm{HPD}_{95 \%}=$ High posterior density interval at $95 \%$; $k=$ Limit for the interval $[k,+1)$ of the phenotypic correlation having probability of $95 \%$.

Features of the marginal posterior distributions of the phenotypic correlation between studied traits are shown in Table (4.7). Similar to genetic correlations, phenotypic correlations were also null between LS and growth traits and also positive between OR and growth traits. 


\subsubsection{Response to selection}

In the first period, selection for ovulation rate during six generations improved OR in 0.24 ova per generation (corresponding to an improvement of $1.5 \%$ per generation) and a low correlated response on litter size was found (0.07 kits per generation, $0.8 \%$ per generation; chapter 3 ). For growth traits, a correlated response on WW, MW and GR was found, 2.7, 11.3 and 8.5 grams per generation, which means an improvement around $0.5 \%, 0.7 \%$ and $0.7 \%$ per generation, respectively (Figure 4.1 ).

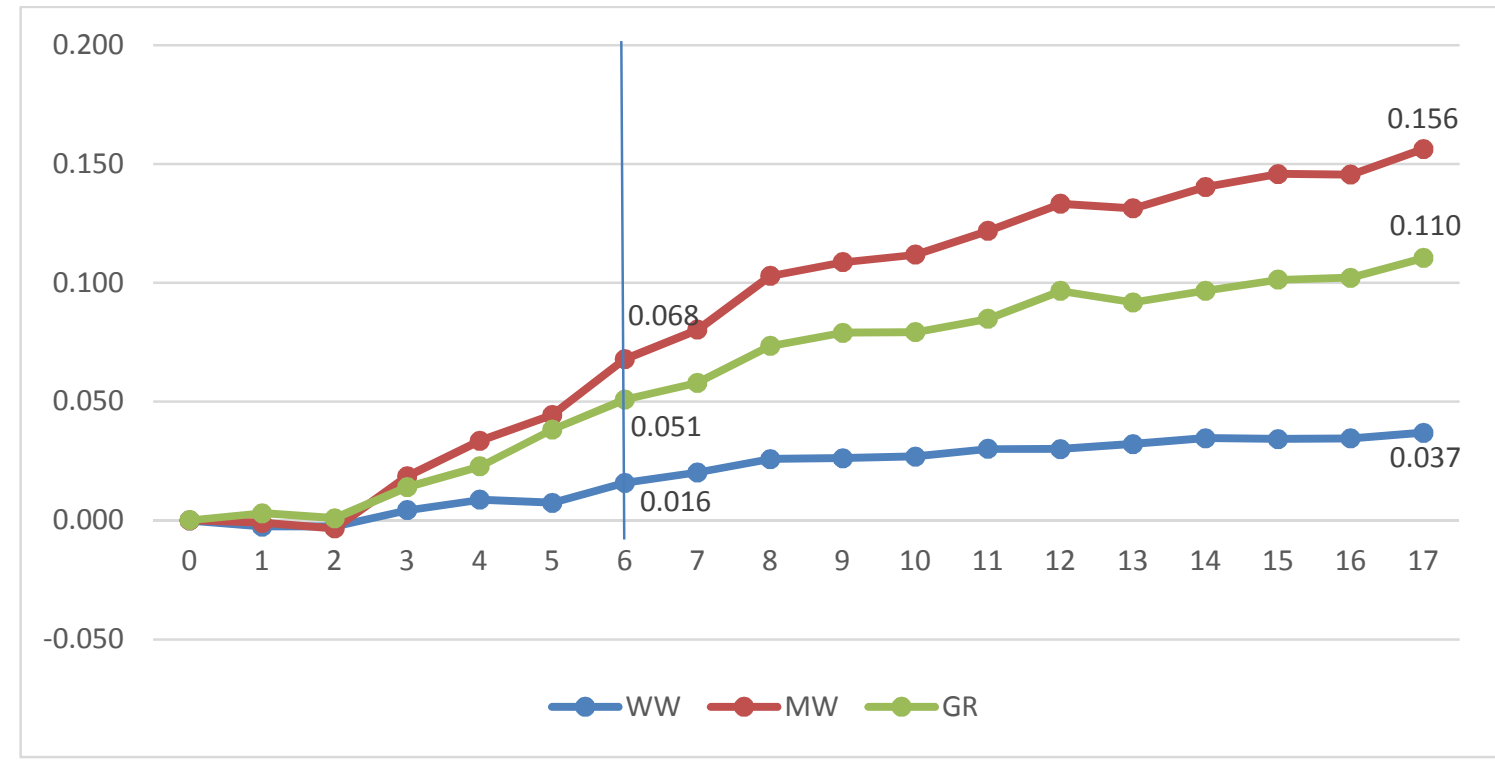

Figure 4.1. Genetic trends for weaning weight (WW; kg), marketing weight (MW; kg) and growth rate $(\mathrm{GR} ; \mathrm{kg}$ ) of OR-LS line, initially selected for ovulation rate at second gestation from generation 0 to 6 and later for ovulation rate at second gestation and litter size of the first two parities from generation 7 to 17.

In the second period of selection, an improvement in litter size was observed after 11 generations of two-stage selection ( 0.17 kits, i.e. $1.9 \%$ per generation; chapter 3$)$, due to the improvement in both components of litter size, OR $(0.17$ ova, i.e. $1.01 \%$ per generation) and PS (0.01, i.e. $1.7 \%$ per generation). During this second period of 
selection, the correlated response on growth traits was lower; 1.9, 8.0 and 5.4 grams, which means an improvement around $0.4 \%, 0.5 \%$ and $0.4 \%$ per generation for WW, MW and GR, respectively. The positive moderate genetic correlation estimated between OR and MW could explain the differences between two selection periods. During the first period of selection, a higher increase of ovulation rate was achieved, as it was quoted before, and therefore a higher correlated response on MW was obtained. Correlated response on WW could be explained by positive and high genetic correlation between WW and MW, since WW was slightly related to OR. No mention is done to GR since it is the difference between MW and WW and therefore all the comments done for both weights also apply. Similar correlated response on growth traits was observed in a line selected for ovulation in rabbits (Quirino et al., 2009) and in pigs (Rosendo et al., 2007). Another possible explanation for the obtained correlated response on growth traits could be an unintentional selection for growth traits when future breeding animals were selected for ovulation and litter size traits.

When using litter size as selection criteria, no clear pattern was found. In four maternal lines selected by litter size at weaning, Mínguez et al. (2016) found positive correlated response on growth traits. Previous results in V line, one of the four lines mentioned above, showed no correlated response on growth traits using genetic trends and a cryopreservated population (García and Baselga, 2002b). However, negative and low correlated response on MW and adult weight were obtained using a control line by Rochambeau (1998).

As commercial weight is determined by the market, an increase of MW should lead to slaughter earlier animals. This implies that the maintenance cost is reduced. However, slaughtering younger animals at the same commercial weight implies having lower carcass yield. Besides, weights are genetically correlated and an increase on MW 
could lead to an increase in adult weight as it was stressed by Blasco et al. (2003). Higher adult weights lead more maintenance cost and could lead to animals difficult to handle and with higher percentage of sore hocks. On the other hand, lower adult weight could reduce reproductive performance as it was suggested by Rochambeau (1998). Therefore, it is unknown the optimum adult weight to achieve the maximum benefit for this reproductive line in a three way crosses.

\subsection{CONCLUSION}

An improvement for growth traits, WW, MW and GR, was observed in both periods of selection. Correlated response on growth traits could be due to the positive moderate genetic correlation estimated between OR and MW or/and to unintentional selection for growth traits when future breeding animals were selected for ovulation and litter size traits.

\subsection{REFERENCES}

Baselga, M. (2004). Genetic improvement of meat rabbits. Programs and diffusion. In: Proceeding $8^{\text {th }}$ World Rabbit Congress, Puebla, Mexico. Volume 1: 1-13.

Bidanel, J. P., J. Gruand and C. Legault (1996). Genetic variability of age and weight at puberty, ovulation rate and embryo survival in gilts and relationship with production traits. Genetics Selection Evolution, 28: 103-115.

Blasco, A., J. A. Ortega, M. A. Santacreu and A. Climent (2005). Divergent selection for uterine capacity in rabbits. I. Genetic parameters and response to selection. Journal of Animal Science, 83: 2297-2302. 
Blasco, A., M. Piles and L. Varona (2003). A Bayesian analysis of the effect of selection for growth rate on growth curves in rabbits. Genetics Selection Evolution, 35: 21-41.

Brun J. M. and J. Ouhayoun (1994). Qualités bouchères de lapereaux issus d'un croisement diallèle de 3 souches: interaction du type génétique et de la taille de portée d'origine. Annales de Zootechnie, 43: 173-183.

Cartuche, L., M. Pascual, E. A. Gómez and A. Blasco (2014). Economic weights in rabbit meat production. World Rabbit Science, 22: 165-177.

García, M. L. and M. Baselga (2002b). Estimation of correlated response on growth traits to selection in litter size of rabbits using cryopreserved control population and genetic trends. Livestock Production Science, 78: 91-98.

García, M. L. and M. Baselga. (2002a). Genetic response to selection for reproductive performance in a maternal line of rabbits. World Rabbit Science, 10: 71-76.

Gómez, E. A., O. Rafel, and J. Ramon (2000). Preliminary genetic analysis of caldes line: A selection experiment for a global objective. In: Proceeding $7^{\text {th }}$ World Rabbit Congress, Valencia, Spain. Volume 1: 417-423.

Legarra, A., L. Varona and E. López de Maturana (2008). Program TM. http://snp.toulouse.inra. fr/ alegarra/

McNitt, J. I. and S. D. Lukefahr (1996). Genetic and environmental parameters for postweaning growth traits of rabbits using an animal model. In: Proceeding $6^{\text {th }}$ World Rabbit Congress, Toulouse, France. Volume 2: 325-329. 
Mínguez, C., J. P. Sánchez, A. G. El Nagar, M. Ragab and M. Baselga (2016). Growth traits of four maternal lines of rabbits founded on different criteria: comparisons at foundation and at last periods after selection. Journal of Animal Breeding and Genetics, 133: 303-315.

Mocé, M. L. and M. A. Santacreu (2010). Genetic improvement of litter size in rabbits: a review. In: $C D$ Proceeding $9^{\text {th }}$ World Congress on Genetics Applied to Livestock Production, Leipzig, Germany. Communication 25.

Quirino, C. R., R. Peiró, M. A. Santacreu and A. Blasco (2009). Genetic correlation between liveweight and ovulation rate in rabbits. In: Proceeding $60^{\text {th }}$ Annual Meeting of European Association of Animal Science, Barcelona, Spain. Volume 1: $1-5$.

Ragab, M. and M. Baselga (2011) A comparison of reproductive traits of four maternal lines of rabbits selected for litter size at weaning and founded on different criteria. Livestock Science, 136: 201-206.

Rochambeau H. de. (1998). La femelle parentale issue des souches expérimentales de 1'INRA: évolutions génétiques et perspectives. In : Proceeding $7^{\text {émes }}$ Journées de la Recherché Cunicole, Lyon, France. Volume 1: 3-14.

Rochambeau, H. de. (1988). Genetic of rabbit for wool and meat production. In: Proceeding $4^{\text {th }}$ World Rabbit Congress, Budapest, Hungary. Volume 2: 1-68.

Rosendo, A., L. Canario, T. Druet, J. Gogue and J. P. Bidanel (2007). Correlated responses of pre- and postweaning growth and backfat thickness to six generations of selection for ovulation rate or prenatal survival in French Large White pigs. Journal of Animal Science, 85: 3209-3217. 
Sorensen, D. and D. Gianola (2002). Likelihood, Bayesian, and MCMC methods in quantitative genetics. Springer-Verlag, New York, United States.

Young, L. D., I. T. Omtvedt and R. K. Johnson (1974). Relationships of various measures of performance with ovulation rate and number of embryos 30 days after breeding in gilts. Journal of Animal Science, 39: 480-487. 



\section{CHAPTER FIVE}





\title{
CHAPTER 5
}

\section{Effect of Increased Ovulation Rate on Embryo and Foetal Survival as A Model for Selection by Ovulation Rate in Rabbits}

\author{
Badawy A.Y.*†, Peiró R.*†, Blasco A.*, Santacreu M.A.* \\ *Instituto de Ciencia y Tecnología Animal, Universitat Politècnica de València, \\ 46022 Valencia, Spain. \\ $\dagger$ Animal Production Department, Faculty of Agriculture, Suez Canal University, \\ 41522 Ismailia, Egypt. \\ †Instituto de Conservación y Mejora de la Agrodiversidad Valenciana, Universitat \\ Politècnica de València, 46022 Valencia, Spain.
}

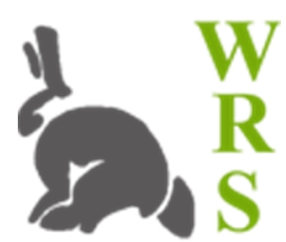

World Rabbit Sci. 2016, 24: 87-94

doi:10.4995/wrs.2016.3992

(C) WRSA, UPV, 2003

Acknowledgements: This study was supported by the Comisión Interministerial de Ciencia y Tecnología CICYT- AGL2011-29831-C03-01 and by funds from Generalitat Valenciana research programme (Prometeo 2009/125). A.Y. Badawy was supported by a grant of the Egyptian Ministry of Higher Education. 



\subsection{ABSTRACT}

Selection for ovulation rate in prolific species has not improved litter size, due to an increase in prenatal mortality, with most mortality observed in the foetal period. The aim of this study was to investigate the magnitude and timing of embryo and early foetal survival in females with high ovulation rate using hormonal treatment as a model for selection by ovulation rate. Two groups of females (treated and untreated) were used. Treated females were injected with 50 IU equine chorionic gonadotropin $48 \mathrm{~h}$ before mating. Females were slaughtered at day 18 of gestation. Ovulation rate (OR), number of implanted embryos (IE), number of live foetuses at days 12 and 18 (LF 12 and $\mathrm{LF}_{18}$, respectively) were recorded. In addition, embryo survival (ES=IE/OR), foetal survival at day 18 of gestation $\left(\mathrm{FS}_{\mathrm{LF} 18}=\mathrm{LF}_{18} / \mathrm{IE}\right)$, foetal survival between 12 and 18 days of gestation $\left(\mathrm{FS}_{\mathrm{LF} 18 / \mathrm{LF} 12}=\mathrm{LF}_{18} / \mathrm{LF}_{12}\right)$ and prenatal survival $\left(\mathrm{PS}_{\mathrm{LF} 18}=\mathrm{LF}_{18} / \mathrm{OR}\right)$ were estimated. For each female, the mean and variability of the weight for live foetuses (LFWm and LFWv, respectively) and their placentas (LFPWm and LFPWv, respectively) were calculated. Treated females had a higher ovulation rate (+3.02 ova) than untreated females, with a probability of 0.99 . An increase in the differences (D) between treated and untreated females was observed from implantation to day 18 of gestation $\left(\mathrm{D}=-0.33,-0.70\right.$ and -1.28 for $\mathrm{IE}, \mathrm{LF}_{12}$ and $\mathrm{LF}_{18}$, respectively). These differences had a low accuracy and the probability that treated females would have a lower number of foetuses also increased throughout gestation $(0.60,0.70$ and 0.86 for IE, $\mathrm{LF}_{12}$ and $\mathrm{LF}_{18}$, respectively). According to the previous results for $\mathrm{OR}$ and $\mathrm{LF}_{18}$, treated females showed a lower survival rate from ovulation to day 18 of gestation $(D=$ $-0.12, P=0.98$ for $\left.\mathrm{PS}_{\mathrm{LF} 18}\right)$. Treated females also had lower embryo and foetal survival $\left(\mathrm{D}=-0.10\right.$ and $P=0.94$ for $\mathrm{ES}$ and $\mathrm{D}=-0.08$ and $P=0.93$ for $\left.\mathrm{FS}_{\mathrm{LF} 18}\right)$. Main differences in foetal survival appeared from day 12 to 18 of gestation $(\mathrm{D}=-0.09$ and $P=0.98$ for 


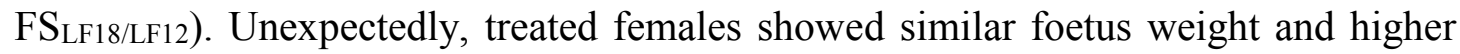
foetal placenta weight than untreated females $(\mathrm{D}=0.25 \mathrm{~g}, P=0.98)$ and lower variability for these traits $(\mathrm{D}=-0.02 \mathrm{~g}, P=0.72$ for LFWv and $\mathrm{D}=-0.05 \mathrm{~g}, P=0.83$ for LFPWv). These results are not related to a lower number of IE or $\mathrm{LF}_{18}$. Thus, the effect of increasing by three ova in rabbits leads to a lower embryo and early foetal survival. There seems to be no relationship between foetal mortality and foetus weight.

Key Words: early foetal survival, embryo survival, high ovulation rate, rabbit. 


\subsection{INTRODUCTION}

Increased ovulation rate has been considered as a way to improve litter size in both rabbits and pigs. However, selection for ovulation rate did not improve litter size, due to an increase in prenatal mortality (Laborda et al., 2011, 2012a in rabbits; Leymaster and Christenson, 2000; Rosendo et al., 2007 in pigs). In rabbit selection experiments for ovulation rate, most of the mortality was observed during the foetal period, which comprises the period from implantation to birth (Laborda et al., 2012a). Similar results were found in a line selected for ovulation rate in pigs (Freking et al., 2007). A better knowledge of the timing of foetal mortality in females with high ovulation rate is needed to propose alternative ways of improving litter size. In rabbit, most foetal mortalities occur until the day 18 of gestation. Early foetal period (between 8 and 18 days of gestation) is critical for foetal survival, as the placenta initiates controlling foetal nutrition during this period (Adams, 1960a). Moreover, placental development is related to foetal growth and survival (Argente et al., 2003 in rabbits; Knight et al., 1977 in pigs).

When there is no control population to study the effect of selection for ovulation rate on survivals traits, the effect of selection for ovulation rate can be modeled by implementing a low dose hormonal treatment in females, as previously proposed by Van der Waaij et al. (2010) in pigs. The aim of this study was to investigate the magnitude and timing of embryo and early foetal survival in females with high ovulation rate, using hormonal treatment as a model for selection by ovulation rate. Furthermore, the foetus and placenta weights were studied to assess the influence of a high ovulation rate on foetal and placental development at day 18 of gestation. 


\subsection{MATERIALS AND METHODS}

All experimental procedures involving animals were approved by the Universitat Politècnica de València Research Ethics Committee.

\subsubsection{Animals}

A total of 51 multiparous rabbit females from a line selected by ovulation rate and litter size for 14 generations were used. Details of this line can be found in Ziadi et al. (2013). Animals were housed at the selection farm of the Universitat Politècnica de València in individual cages and fed a commercial diet. Animals were reared under a photoperiod of 16-h light: 8-h dark.

\subsubsection{Treatment with eCG}

Females were randomly distributed in 2 groups: (i) control group with 27 females, and (ii) hormonal treated group in which 24 does were treated i.m. with a dose of $50 \mathrm{IU}$ equine chorionic gonadotropin (eCG; Folligon ${ }^{\circledR}$, Intervet Ireland Ltd, Dublin) $48 \mathrm{~h}$ before mating. This dose was used because previous results had shown an increase in the number of ova without reducing the early embryo survival and development (Mehaisen et al., 2005). Natural mating was carried out 10 days after the last parturition. Abdominal palpation was performed 12 days after mating. Pregnant females were slaughtered by stunning and exsanguination at day 18 of gestation.

\subsubsection{Traits}

After slaughter, the complete reproductive tract was removed. Ovulation rate (OR, ova) was determined by counting the number of corpora lutea in both ovaries. Both ovaries were weighted (OW, gr). Implantation sites were determined by uterine horn examination and classified according to presence of atrophic maternal placenta, foetal placenta, and dead and/or live foetuses. The following traits were recorded: number of sites with presence of only atrophic maternal placenta (MP), number of sites 
with presence of maternal and foetal placenta without foetus (FP), number of sites with presence of both placentas and dead foetus $\left(\mathrm{DF}_{18}\right)$ and number of sites with presence of both placentas and live foetus $\left(\mathrm{LF}_{18}\right)$. All foetuses and corresponding foetal placentas were removed from the uterine horn. Live foetuses were individually weighed after removal of placental membranes and fluids. Foetal placentas were also weighed, distinguishing between live and dead foetus placenta. For each female, the mean of the weight for live foetuses (LFWm), foetal placenta for live foetuses (LFPWm) and foetal placenta for dead foetuses (DFPWm) were estimated. Additionally, the variability of the live foetus weight (LFWv) and live foetus placental weight (LFPWv) for each female was calculated as a standard deviation.

Number of implanted embryos (IE) was estimated as the sum of MP, FP, DF 18 and $\mathrm{LF}_{18}$. Total number of foetuses at 18 days of gestation $\left(\mathrm{TF}_{18}\right)$ was estimated as the sum of $\mathrm{LF}_{18}$ and $\mathrm{DF}_{18}$. Foetal placenta initiates the control of foetal nutrition around 12 days of gestation, thus the number of live foetuses at 12 days $\left(\mathrm{LF}_{12}\right)$ was estimated as the number of implanted embryos minus the number of sites with only maternal placenta $\left(\mathrm{LF}_{12}=\mathrm{IE}-\mathrm{MP}\right)$. Embryo survival $(\mathrm{ES})$ was calculated as the ratio between IE and OR. Foetal survival at 12 days of gestation $\left(\mathrm{FS}_{\mathrm{LF} 12}\right)$ was estimated as the ratio between $\mathrm{LF}_{12}$ and IE.

Similarly, foetal survival at 18 days of gestation $\left(\mathrm{FS}_{\mathrm{LF18}}\right)$ was estimated as $\mathrm{LF}_{18} / \mathrm{IE}$. Besides, $\mathrm{FS}_{\mathrm{LF} 18 / \mathrm{LF} 12}$ was estimated as the ratio between $\mathrm{LF}_{18}$ and $\mathrm{LF}_{12}$. Prenatal survival (PS $\mathrm{LF18}_{18}$ ) was estimated as the ratio between $\mathrm{LF}_{18}$ and $\mathrm{OR}$.

\subsubsection{Statistical Analyses}

The analysis was based on Bayesian methods. Bounded uniform priors were used for all unknowns, and data were assumed to be normally distributed. 
To estimate differences between effects, the following model was fitted for OR, OW, IE, $\mathrm{LF}_{12}, \mathrm{LF}_{18}, \mathrm{TF}_{18}$ and survival rates and weight traits:

$$
\mathrm{y}_{\mathrm{ijk}}=\mathrm{T}_{\mathrm{i}}+\mathrm{L}_{\mathrm{j}}+(\mathrm{T} \times \mathrm{L})_{\mathrm{ij}}+\mathrm{e}_{\mathrm{ijk}}
$$

where $T_{i}$ is the effect of the treatment (treated and control group), $L_{j}$ is the effect of the lactation status (lactated and non-lactated female), $\mathrm{T} \times \mathrm{L}_{\mathrm{ij}}$ is the effect of the interaction (treatment and lactation status) and $\mathrm{e}_{\mathrm{ijk}}$ is the residual effect. Weight traits and their variability were also analysed with the same model including number of foetus at 18 days of gestation as a covariate.

Marginal posterior distributions of all unknowns were estimated by Gibbs Sampling (Sorensen and Gianola, 2002). The TM program developed by Legarra et al. (2008) was used for all Gibbs sampling procedures. After some exploratory analyses, we used one chain of $1,000,000$ samples, discarding the first 200,000 and saving every 100 thereafter. The Monte Carlo standard error (MCse) was estimated and convergence was tested using the $\mathrm{Z}$ criterion of Geweke as shown by Sorensen and Gianola (2002).

\subsection{RESULTS AND DISCUSSION}

Only one selection experiment for ovulation rate has been carried out in rabbits. In that experiment, ovulation rate responded to selection, but no correlated response on litter size was obtained due to a decrease in prenatal survival (Laborda et al., 2012a). There is little information on magnitude and timing of prenatal mortality in rabbits selected for ovulation rate. This selection process can be modelled implementing an adequate hormonal treatment in females. Comparing hormonal treated and untreated females allows us to assess the effect of the increased ovulation rate on prenatal survival and its components (embryo and foetal survival). 
Raw means and standard deviation for untreated females are shown in Table 5.1.

Ovulation rate was higher than in other maternal lines selected by litter size (15 ova;

García and Baselga, 2002) and uterine capacity (14.8; Santacreu et al., 2005), as the females used in this experiment came from a line selected for ovulation rate and litter size. Similar ovulation rate, around 16.4 ova, was published by Laborda et al. (2011) in a line selected by ovulation rate over 10 generations. Number of implanted embryos was within the range of all lines previously quoted, and embryo survival was lower (0.66 vs. 0.82 to 0.87$)$.

Table 5.1. Raw mean, standard deviation (SD) and coefficient of variation (CV) for studied traits for untreated females.

\begin{tabular}{|c|c|c|c|}
\hline Trait & Mean & SD & CV (\%) \\
\hline$\overline{\text { OR }}$ & 17.35 & 3.59 & 20.7 \\
\hline OW & 1.50 & 0.27 & 18.1 \\
\hline $\mathrm{IE}$ & 11.67 & 4.18 & 35.8 \\
\hline $\mathrm{LF}_{12}$ & 10.41 & 4.30 & 41.3 \\
\hline $\mathrm{TF}_{18}$ & 9.15 & 3.93 & 43.0 \\
\hline $\mathrm{LF}_{18}$ & 8.93 & 3.94 & 44.2 \\
\hline $\mathrm{ES}$ & 0.66 & 0.19 & 28.7 \\
\hline $\mathrm{FS}_{\mathrm{LF} 12}$ & 0.87 & 0.13 & 15.4 \\
\hline $\mathrm{FS}_{\mathrm{LF} 18 / \mathrm{LF} 12}$ & 0.85 & 0.13 & 15.8 \\
\hline $\mathrm{FS}_{\mathrm{LF} 18}$ & 0.75 & 0.17 & 22.5 \\
\hline $\mathrm{PS}_{\mathrm{LF} 18}$ & 0.50 & 0.19 & 37.8 \\
\hline LFWm & 1.93 & 0.37 & 19.3 \\
\hline LFPWm & 2.24 & 0.42 & 18.9 \\
\hline DFPWm & 0.60 & 0.31 & 51.9 \\
\hline LFWv & 0.24 & 0.10 & 41.8 \\
\hline LFPWv & 0.43 & 0.15 & 34.4 \\
\hline
\end{tabular}

$\mathrm{OR}=$ Ovulation rate, $\mathrm{OW}=$ Ovaries weight $(\mathrm{g}), \mathrm{IE}=$ Number of implanted embryos, $\mathrm{LF}_{12}=$ Number of live foetuses at 12 days of gestation, $\mathrm{TF}_{18}=$ Total number of foetuses at 18 days of gestation, $\mathrm{LF}_{18}=$ Number of live foetuses at 18 days of gestation, $\mathrm{ES}=$ Embryo survival, $\mathrm{FS}_{\mathrm{LF} 12}=$ Foetal survival of live foetuses at 12 days of gestation, $\mathrm{FS}_{\mathrm{LF} 18}=$ Foetal survival of live foetuses at 18 days of gestation, $\mathrm{FS}_{\mathrm{LF} 18 / \mathrm{LF} 12}=$ foetal survival between 12 and 18 days of gestation, $\mathrm{PS}_{\mathrm{LF} 18}=$ Prenatal survival of live foetuses at 18 days of gestation, LFWm=Live foetus weight (g), LFPWm=Live foetus placental weight (g), DFPWm=Dead foetus placental weight (g), $\mathrm{LFWv}_{\mathrm{v}}=$ Variability on live foetus weight $(\mathrm{g}), \mathrm{LFPWv}_{\mathrm{v}}=$ Variability on live foetus placental weight $(\mathrm{g})$. 
There is only scarce information about foetal traits at 18 day of gestation. Similar numbers of live foetuses at 18 day of gestation $\left(\mathrm{LF}_{18}\right)$ but lower FSLF18 (0.75 vs. 0.90$)$ and $\mathrm{PS}_{\mathrm{LF} 18}(0.50$ vs. 0.73$)$ were obtained comparing with a line selected for uterine capacity (Argente et al., 2008). Regarding the weight, similar LFWm and higher LFPWm from untreated females were found compared to the line quoted previously, which had similar IE (Argente et al., 2006).

\subsubsection{Ovulation rate, number of implanted embryos and foetuses}

Features of the estimated marginal posterior distributions of the differences between treated and untreated females for $\mathrm{OR}, \mathrm{OW}, \mathrm{IE}, \mathrm{LF}_{12}, \mathrm{TF}_{18}$ and $\mathrm{LF}_{18}$ are shown in Table 5.2. All MCse were very small and lack of convergence was not detected by the Geweke test. Marginal posterior distributions were approximately normal, thus mean, mode and median were similar.

Treated females had roughly 3 ova more than untreated females $(\mathrm{P}=0.99$, Table 5.2), in agreement with previous results in rabbits (Mehaisen et al., 2005). Low concentration of eCG was used to increase ovulation rate to a level similar to that obtained after ten generations of selection for ovulation rate (Laborda et al., 2012b). In this selection experiment, an increase of 2.1 ova [highest posterior density region of the difference at $\left.95 \%\left(\mathrm{HPD}_{95 \%}\right)=1.3,2.9\right]$ was estimated but no correlated response on litter size was found due to a decrease in prenatal survival (-0.12 kits). In the present experiment, the probability that treated females would show 1 or 2 ova more than the untreated females was high, 0.95 and 0.80 , respectively. Moreover, the probability of a difference between treated and untreated females higher than 6 ova was close to zero (0.01). Based on results obtained by Mehaisen et al. (2005), we assume that the low increment in ovulation rate obtained in the present work using $50 \mathrm{UI}$ eCG did not affect early embryo survival and development. Thus, the increase in ovulation rate using this 
hormone and dose could be a good model to provide some insight into the negative consequences on prenatal survival due to increased ovulation rate by selection. A disadvantage of using a hormonal treatment model is that the effect of selection for ovulation rate on other genetic correlated traits is not considered. There was no important difference between treated and untreated females for OW (Table 5.2). No information was found about the effect of increased OR on the ovary weight when superovulation treatment was applied. Comparing intact and unilateral ovariectomised females, Argente et al. (2008) reported the increased ovulation rate as a reason for increasing ovary weight; these authors showed that the ovary weight augmented $50 \%$ when a duplication of OR in the remaining functional ovary was achieved.

An increase in the posterior mean differences (D) between treated and untreated females was observed from implantation (IE) to 18 day of gestation $\left(\mathrm{LF}_{18}\right) ; \mathrm{D}=-0.33$, 0.70 and -1.28 for IE, $\mathrm{LF}_{12}$ and $\mathrm{LF}_{18}$, respectively. These estimated differences had a low accuracy (see high HPD95\%, Table 5.2) and the probability that treated females would have a lower number of foetuses also increased along gestation $(\mathrm{P}=0.60,0.70$ and 0.86 for IE, $\mathrm{LF}_{12}$ and $\mathrm{LF}_{18}$, respectively). Difference between treated and untreated females for $\mathrm{TF}_{18}$ was similar to difference for $\mathrm{LF}_{18}$, so similar numbers of dead foetuses were reached.

\subsubsection{Survival rates}

According to the previous results for $\mathrm{OR}$ and $\mathrm{LF}_{18}$, treated females showed a lower survival rate from ovulation to 18 day of gestation $\left(\mathrm{D}=-0.12, \mathrm{P}=0.98\right.$ for $\mathrm{PS}_{\mathrm{LF} 18}$, Table 5.3). In the rabbit selection experiment for ovulation rate cited earlier, the estimated difference between selected and control lines for prenatal survival from ovulation to birth was the same, $-0.12\left(\mathrm{HPD}_{95 \%}=-0.20,-0.04\right.$; Laborda et al., 2012b). The results confirmed that a moderate increased of ovulation rate by hormonal 
treatment could be used to assess the timing of prenatal mortality in ovulation rate selection experiments.

Table 5.2. Mean of the posterior distribution for treated and untreated females and features of the marginal posterior distributions of the differences between treated and untreated females for ovulation rate (OR, ova), ovaries weight $(\mathrm{OW}, \mathrm{g})$, number of implanted embryos (IE), number of live foetuses at 12 day of gestation $\left(\mathrm{LF}_{12}\right)$, total number of foetus at 18 day of gestation $\left(\mathrm{TF}_{18}\right)$, and number of live foetuses at 18 day of gestation $\left(\mathrm{LF}_{18}\right)$.

\begin{tabular}{lccccc}
\hline \multicolumn{1}{c}{ Trait } & Treated & Untreated & D & HPD95\% & $P$ \\
\hline OR & 20.54 & 17.45 & 3.02 & {$[0.60,5.35]$} & 0.99 \\
OW & 1.50 & 1.50 & -0.01 & {$[-0.19,0.17]$} & 0.53 \\
$\mathrm{IE}$ & 11.41 & 11.68 & -0.33 & {$[-3.03,2.30]$} & 0.60 \\
$\mathrm{LF}_{12}$ & 9.78 & 10.43 & -0.70 & {$[-3.33,1.88]$} & 0.70 \\
$\mathrm{TF}_{18}$ & 8.00 & 9.16 & -1.21 & {$[-3.69,1.21]$} & 0.84 \\
$\mathrm{LF}_{18}$ & 7.70 & 8.93 & -1.28 & {$[-3.67,1.06]$} & 0.86 \\
\hline
\end{tabular}

$\mathrm{D}=$ Posterior mean of differences between treated and untreated females, $\mathrm{HPD}_{95 \%}=$ Highest posterior density region of the difference at $95 \%, P=$ Probability of the difference being higher than zero when $\mathrm{D}>0$ or lower than zero when $\mathrm{D}<0$.

In rabbit, it is accepted that prenatal survival comprises an embryonic period (before implantation, day 7) and a foetal period (after implantation) (Mocé et al., 2010). For embryonic period, treated females showed lower survival $(D=-0.10$ and $P=0.94$ for ES; Table 5.3). Higher embryo loss has been reported in selected females for ovulation rate in rabbits and pigs. To our knowledge, there is no information about the effect of high ovulation rate on fertilisation rate. Usually, embryo mortality includes fertilisation failures and embryo losses. After 10 generations of selection by ovulation rate in rabbits, a negative correlated response on embryo survival, -0.05 (HPD95\% $=-$ $0.12,0.02)$, was observed when the selected line was compared to a control line (Laborda et al., 2012b). Besides, in pigs, Koenig et al. (1986) found a higher proportion 
of immature ova in selected females for high ovulation rate compared to unselected females, and in superovulated females compared to naturally ovulated ones; they suggest that immaturity of ova may account for a substantial proportion of prenatal mortality in gilts with high ovulation rate, either before or after implantation. Moreover, a second cause of this increase in embryo mortality could be a higher variability in embryonic development as a result of longer processing time of ovulation. Oocytes which ovulate first are fertilised earlier and advance the uterine secretions (Torres et al., 1984 in rabbits; Pope, 1988 and Xie et al., 1990 in pigs; Wilmut et al., 1986 and Al-Shorepy et al., 1992 in mice). Asynchrony between embryonic development and uterine secretions can cause embryo mortality, as shown in asynchronous embryo transfer experiments in rabbits (Wintenberger-Torres, 1974; Torres et al., 1987). For foetal period comprised from implantation to 18 days of gestation, treated females also had lower survival $\left(\mathrm{D}=-0.08\right.$ and $\mathrm{P}=0.93$ for $\mathrm{FS}_{\mathrm{LF} 18}$; Table 5.3). A decrease in foetal survival, from implantation to birth, has also been reported in rabbit females with high ovulation rate after 10 generations of selection for ovulation rate, $-0.12\left(\mathrm{HPD}_{95 \%}=\right.$ $-0.19,-0.6$; Laborda et al., 2012b). Based on the presence or absence of foetal placenta by uterine horn examination, foetal survival from implantation to 12 days of gestation was estimated and no difference between treated and untreated females was found $(D=$ -0.01 and $\mathrm{P}=0.63$ for $\mathrm{FS}_{\mathrm{LF} 12}$; Table 5.3). Thus, the main difference in foetal survival appeared from 12 to 18 days of gestation $\left(\mathrm{D}=-0.09\right.$ and $\mathrm{P}=0.98$ for $\left.\mathrm{FS}_{\mathrm{LF} 18 / \mathrm{LF} 12}\right)$. The number of dead foetuses present at 18 day of gestation is very low in both treated and untreated females (see mean values for $\mathrm{TF}_{18}$ and $\mathrm{LF}_{18}$, Table 5.2), therefore differences in foetal survival probably occur shortly after 12 day of gestation. This is a critical period for foetal survival because the placenta begins controlling foetal nutrition (Adams, 1960b). 
In agreement with these results obtained in rabbits, most prenatal mortality occurred during the early foetal period in an experiment of selection for ovulation rate in pigs (Freking et al., 2007). In females with high ovulation rate, foetal mortality could be due to competition among foetuses for uterine space and resources (Adams, 1960a, b, Hafez, 1969 and Argente et al. 2008, in rabbits; Geisert and Schmitt, 2002 in pigs). However, no difference in IE between treated and untreated females was found, thus higher foetal mortality in treated females cannot be attributed to higher competition among foetuses. Both oocyte quality and embryo development variability can also affect foetal survival. It has been shown that low quality embryos and lesser developed embryos can be implanted, although they will probably die later (Wintenberger-Torres et al., 1974 in rabbits; Pope, 1988; Wilde et al., 1988 in pigs).

\subsubsection{Placenta and foetus weight}

Table 5.4 shows features of the estimated marginal posterior distributions of the differences between treated and untreated females for weights of foetuses and their placentas, used to assess the influence of a high ovulation rate on foetal and placental development at 18 day of gestation. For weight of live foetuses, we found no differences between treated and untreated females, although the estimation had a low accuracy (see high HPD95\%, Table 5.4). Unexpectedly, foetal placenta weight of live foetuses in the treated females was heavier than in untreated ones $(\mathrm{D}=0.25 \mathrm{~g} ; P=0.98)$. A similar result was obtained for foetal placenta weight of dead foetuses. In rabbits, Argente et al. (2008) observed that each additional foetus implied a decrease in the blood flow that reached each foetus, reducing foetal and placental weight. Thus, higher placenta weight could be associated with a lower number of developed foetuses in treated females between 12 and 18 days of gestation $\left(D=-0.70\right.$ and -1.21 foetus for $L_{12}$ and $L_{18}$, 
respectively); however, estimated differences for LFPWm and DFPWm were similar when $\mathrm{LF}_{18}$ was included as a covariate (data not shown).

Table 5.3. Mean of the posterior distribution for treated and untreated females and features of the marginal posterior distributions of the differences between treated and untreated females in embryo survival (ES), foetal survival of live foetuses at both $12\left(\mathrm{FS}_{\mathrm{LF12}}\right)$ and $18\left(\mathrm{FS}_{\mathrm{LF1} 18}\right)$ days of gestation, foetal survival between 12 and 18 days of gestation $\left(\mathrm{FS}_{\mathrm{LF} 18 / \mathrm{LF} 12}\right)$, prenatal survival of live foetuses at 18 day of gestation ( $\left.\mathrm{PS}_{\mathrm{LF} 18}\right)$.

\begin{tabular}{lccccc}
\hline \multicolumn{1}{c}{ Trait } & Treated & Untreated & D & HPD95\% & $\boldsymbol{P}$ \\
\hline ES & 0.56 & 0.66 & -0.10 & {$[-0.23,0.03]$} & 0.94 \\
FS $_{\text {LF12 }}$ & 0.86 & 0.87 & -0.01 & {$[-0.10,0.07]$} & 0.63 \\
FS $_{\text {LF18/LF12 }}$ & 0.77 & 0.85 & -0.09 & {$[-0.17,0.00]$} & 0.98 \\
FS $_{\text {LF18 }}$ & 0.67 & 0.75 & -0.08 & {$[-0.19,0.03]$} & 0.93 \\
PS $_{\text {LF18 }}$ & 0.40 & 0.50 & -0.12 & {$[-0.24,-0.01]$} & 0.98 \\
\hline
\end{tabular}

$\mathrm{D}=$ Posterior mean of differences between treated and untreated females, $\mathrm{HPD}_{95 \%}=$ Highest posterior density region of the difference at $95 \%, P=$ Probability of the difference being lower than zero.

Features of the estimated marginal posterior distributions of the differences between treated and untreated females for the variability in weights of live foetuses and their foetal placentas are shown in Table 5.5. Treated females showed a lower variability than untreated females for weights of live foetuses $(D=-0.02 g ; P=0.72)$ and foetal placenta $(\mathrm{D}=-0.05 \mathrm{~g} ; P=0.83)$. The lower observed variability for $L F W v$ and LFPWv in the treated females seems not to be related to the lower number of foetuses at 18 day of gestation, as similar results were obtained when $\mathrm{LF}_{18}$ was included as a covariate (data not shown). In short, treated females showed similar foetus weight and higher foetal placenta weight to untreated females but lower variability for these traits. These results seem not to be related to a lower number of implanted embryos or number of live foetuses at 18 day of gestation. 
Table 5.4. Mean of the posterior distribution for treated and untreated females and features of the marginal posterior distributions of the differences between treated and untreated females in live foetus weight (LFWm, g), live foetus placental weight (LFPWm, g), and dead foetus placental weight (DFPWm, g) at 18 day of gestation.

\begin{tabular}{lccccc}
\hline \multicolumn{1}{c}{ Trait } & Treated & Untreated & D & HPD95\% & $\boldsymbol{P}$ \\
\hline LFWm & 2.00 & 1.93 & 0.03 & {$[-0.17,0.23]$} & 0.62 \\
LFPWm & 2.48 & 2.23 & 0.25 & {$[0.01,0.45]$} & 0.98 \\
DFPWm & 0.83 & 0.61 & 0.21 & {$[-0.08,0.46]$} & 0.93
\end{tabular}

$\mathrm{D}=$ Posterior mean of differences between treated and untreated females, $\mathrm{HPD}_{95 \%}=$ Highest posterior density region of the difference at $95 \%, P=$ Probability of the difference being higher than zero.

Table 5.5. Mean of the posterior distribution for treated and untreated females and features of the marginal posterior distributions of the differences between treated and untreated females in the variability on live foetus weight (LFWv, g) and variability on live foetus placental weight (LFPWv, g) at 18 day of gestation.

\begin{tabular}{lccccc}
\hline \multicolumn{1}{c}{ Trait } & Treated & Untreated & D & HPD95\% & $\boldsymbol{P}$ \\
\hline LFWv & 0.22 & 0.24 & -0.02 & {$[-0.07,0.02]$} & 0.72 \\
LFPWv & 0.38 & 0.43 & -0.05 & {$[-0.12,0.02]$} & 0.83 \\
\hline
\end{tabular}

$\mathrm{D}=$ Posterior mean of differences between treated and untreated females, $\mathrm{HPD}_{95 \%}=$ Highest posterior density region of the difference at $95 \%, P=$ Probability of the difference being lower than zero.

\subsection{CONCLUSION}

In conclusion, a low increase in ovulation rate by hormonal treatment could be a good model to assess consequences on embryo and foetal survival rates due to increased ovulation rate by selection. The effect of increasing by three ova in rabbits leads to a lower embryo and foetal survival. Most foetal mortality occurs shortly after 12 days of gestation, and cannot be attributed to competition among foetuses, as no effects of number of implanted embryos and foetal weight were found. 


\subsection{REFERENCES}

Adams, C. E. (1960a). Prenatal mortality in the rabbit Oryctolagus cuniculus. Journal of Reproduction and Fertility, 1: 36-44.

Adams, C. E. (1960b). Studies on prenatal mortality in the rabbit, Oryctolagus cuniculus: the amount and distribution of loss before and after implantation. Journal of Endocrinology, 19: 325-344.

Al-Shorepy, S. A., A. C. Clutter, R. M. Blair and M. K. Nielsen (1992). Effects of three methods of selection for litter size in mice on preimplantation embryonic development. Biology of Reproduction, 46: 958-963.

Argente, M. J., M. A. Santacreu, A. Climent and A. Blasco (2003). Relationships between uterine and fetal traits in rabbit selected on uterine capacity. Journal of Animal Science, 81: 1265-1273.

Argente, M. J., M. A. Santacreu, A. Climent and A. Blasco (2006). Influence of available uterine space per fetus on fetal development and prenatal survival in rabbits selected for uterine capacity. Livestock Science, 102: 83-91.

Argente, M. J., M. A. Santacreu, A. Climent and A. Blasco (2008). Effect of intrauterine crowding on available uterine space per fetus in rabbits. Livestock Science, 114: 211-219.

Freking, B. A., K. A. Leymaster, J. L.Vallet and R. K. Christenson (2007). Number of fetuses and conceptus growth throughout gestation in lines of pigs selected for ovulation rate or uterine capacity. Journal of Animal Science, 85: 2093-2103.

García, M. L. and M. Baselga (2002). Estimation of genetic response to selection in litter size of rabbits using a cryopreserved control population. Livestock Production Science, 74: 45-53. 
Geisert, R. D. and R. A. M. Schmitt (2002). Early embryonic survival in the pig: Can it be improved? Journal of Animal Science, 80: E54-E65.

Hafez, E. S. E. (1969). Fetal survival in undercrowded and overcrowded unilaterally pregnant uteri in the rabbit. In: Proceeding $6^{\text {th }}$ International Congress on Animal Reproduction and Artificial Insemination, Paris. France. Volume 1: 575.

Knight, J., W. F. W. Bazer, W. W. Thatcher, D. E. Franke and H. D. Wallace (1977). Conceptus development in intact and unilaterally hysterectomizedovariectomized gilts. Interrelations among hormonal status, placental development fetal fluids and fetal growth. Journal of Animal Science, 44: 620637.

Koenig, J. L. F., D. R. Zimmerman F. E. Eldrige and J. D. Kopf (1986). The effect of superovulation and selection for high ovulation rate on chromosomal abnormalities in swine ova. Journal of Animal Science, 63 (Suppl. 1): 202.

Laborda, P., M. A. Santacreu, A. Blasco and M. L. Mocé (2012b). Selection for ovulation rate in rabbits: Direct and correlated responses estimated with a cryopreserved control population. Journal of Animal Science, 90: 3392-3397.

Laborda, P., M. L. Mocé, A. Blasco and M. A. Santacreu (2012a). Selection for ovulation rate in rabbits: Genetics parameters and correlated responses on survival rates. Journal of Animal Science, 90: 439-446.

Laborda, P., M. L. Mocé, M. A. Santacreu and A. Blasco (2011). Selection for ovulation rate in rabbits: Genetic parameters, direct response, and correlated response on litter size. Journal of Animal Science, 89: 2981-2987.

Legarra, A., L. Varona and E. López de Maturana (2008). Program TM. http://snp.toulouse.inra. fr/ alegarra/ 
Leymaster, K. A. and R. Christenson (2000). Direct and correlated responses to selection for ovulation rate or uterine capacity in swine. Journal of Animal Science, 78 (Suppl. 1): 68.

Mehaisen, G. M., J. S. Vicente, R. Lavara and M. P. Viudes-de-Castro (2005). Effect of eCG dose and ovulation induction treatments on embryo recovery and in vitro development post-vitrification in two selected lines of rabbit does. Animal Reproduction Science, 90: 175-184.

Mocé, M. L., A. Blasco and M. A. Santacreu (2010). In vivo development of vitrified embryos: Effects on prenatal survival and placental development. Theriogenology, 73: 704-710.

Pope, W. F. (1988). Uterine asynchrony: A cause of embryonic loss. Biology of Reproduction, 39: 999-1003.

Rosendo, A., T. Druet, J. Gogué and J. P. Bidanel (2007). Direct response to six generations of selection for ovulation rate or prenatal survival in Large White pigs. Journal of Animal Science, 85: 356-364.

Santacreu, M. A., M. L. Mocé, A. Climent and A. Blasco (2005). Divergent selection for uterine capacity in rabbits. II. Correlated response on litter size and its components estimated with a cryopreserved control population. Journal of Animal Science, 83: 2303-2307.

Sorensen, D. and D. Gianola (2002). Likelihood, Bayesian, and MCMC methods in quantitative genetics. Springer-Verlag, New York, United States.

Torres, S., F. Hulot and M. Meunier (1984). Étude comparée du développement et de la mortalité embryonnaire chez deux génotypes de lapines. In: Proceeding $3^{\text {rd }}$ World Rabbit Congress. Rome, Italy. Volume 2: 417-425. 
Torres, S., F. Hulot, M. Meunier and C. Sevellec (1987). Comparative study of preimplantation development and embryonic loss in two rabbit strains. Reproduction Nutrition Development, 27: 707-714.

Van der Waaij, E. H., W. Hazeleger, N. M. Soede, B. F. A. Laurenssen and B. Kemp (2010). Effect of excessive, hormonally induced intrauterine crowding in the gilt on fetal development on day 40 of pregnancy. Journal of Animal Science, 88: 2611-2619.

Wilde, M. H., S. Xie, M. L. Day and W. F. Pope (1988). Survival of small and large littermate blastocysts in swine after synchronous and asynchronous transfer procedures. Theriogenology, 30: 1069-1074.

Wilmut, I., D. I. Sales and C. J. Ashworth (1986). Maternal and embryonic factors associated with prenatal loss in mammals. Journal of Reproduction and Fertility, 76: $851-864$

Wintenberger-Torres, S. (1974). Relation entre la taille des blastocystes de lapine a l'implantation et la survie embryonnaire. Annales de Biologie Animale, Biochimie, Biophysique, 14: 41-52.

Xie, S., D. M. Broermann, K. P. Nephew, R. D. Geisert and W. F. Pope (1990). Ovulation and early embryogenesis in swine. Biology of Reproduction, 43: 236240.

Ziadi, C., M. L. Mocé, P. Laborda, A. Blasco and M. A. Santacreu (2013). Genetic selection for ovulation rate and litter size in rabbits: Estimation of genetic parameters and direct and correlated responses. Journal of Animal Science, 91: $3113-3120$ 
CHAPTER SIX

GENERAL DISCUSSION 



\subsection{BACKGROUND}

In the last decades, demand on rabbit meat has been increased encouraging its production. Reproductive success is an important factor in rabbit production. Improvement of reproductive traits such as litter size and ovulation rate with low cost is a big challenge for scientists and breeders. Short generation interval, early puberty and large litter size are factors which put rabbits in an important position to be a model for genetic studies. Many efforts have been made to improve litter size; these efforts included using the direct selection for litter size and using alternatives ways to achieve the desired goal.

Low response on litter size was obtained by direct selection. Responses estimated in rabbit maternal lines were ranged from 0.05 to 0.13 kits per generation for number of kits born alive and number of kits at weaning (Baselga, 2004). Same trend of genetic response was observed in pigs (Ollivier and Bolet 1981; Holl and Robison, 2003) but higher response was obtained in mice (Bradford, 1968, 1969; Falconer, 1971; Bakker et al., 1978; Gion et al., 1990). The low observed response of litter size may be due to its low genetic variance, highly heterogeneity among parities, low selection intensity and finally negative correlation between direct and maternal effects (Baselga, 2004).

As a result of low response on litter size obtained from direct selection, several authors proposed other traits like ovulation rate, prenatal survival and uterine capacity as alternative criteria of selection to improve litter size in rabbits (Bolet et al., 1994; Blasco et al., 2005; Mocé et al., 2005; Santacreu et al., 2005; Laborda et al., 2011).

Direct selection for litter size led to an increase in ovulation rate (García and Baselga, 2002a in rabbits; Bolet et al., 1989 in pigs; Bakker et al., 1978 and Gion et al., 1990 in mice). Positive genetic correlation between litter size and ovulation rate and 
moderate heritability of ovulation rate supported the proposed of using the ovulation rate as a selection criterion to improve litter size (Blasco et al., 1993).

Different experiments were performed using ovulation rate as a criterion of selection (Laborda et al., 2011 in rabbit; Cunningham et al., 1979; Leymaster and Christenson, 2000; Rosendo et al., 2007 in pigs; Bradford, 1969 and Land and Falconer, 1969 in mice). From these experiments, direct response on ovulation rate was obtained but with a correlated response on litter size lower than that obtained from direct selection. In rabbits, the low response on litter size was attributed to the increase in prenatal mortality (Laborda et al., 2011).

Prenatal survival is the proportion of kits born from the ovulation rate and there is a positive and high genetic correlation between prenatal survival and litter size. Selection for prenatal survival was performed to enhance litter size in pigs (Rosendo et al., 2007) and mice (Bradford, 1969) but correlated response on litter size was lower than direct response.

Selection for uterine capacity was performed in rabbits and mice. In rabbits, uterine capacity was measured as litter size in unilateral ovariectomized females. Low response (1.5 kits) after 10 generations of divergent selection for uterine capacity was reported by Blasco et al. (2005). In mice, Kirby and Nielsen (1993), after 21 generations of selection for uterine capacity, concluded that direct selection for litter size in mice is more effective than selection for uterine capacity. In conclusion, low direct response on uterine capacity and also correlated response on litter size were obtained in both rabbits and mice discouraged the use of uterine capacity to improve litter size.

In pigs and mice, higher response on litter size was predicted when selecting for an index of ovulation rate and prenatal survival (Johnson et al., 1984 and Ribeiro et al., 1997, respectively). However, response on litter size was lower than expected (Johnson 
et al., 1999, in pigs; Kirby and Nielsen, 1993, in mice) probably due to the low accuracy of the genetic correlations and the use of inappropriate economic weights (Falconer and Mackay, 1996).

Ruiz-Flores and Johnson (2001) suggested selection for ovulation rate and litter size using independent culling levels in pigs to avoid the sensitivity of selection index to the estimated genetic correlation. High responses were obtained in litter size $(0.33 \pm$ $0.06 \mathrm{pigs} /$ generation $)$ and ovulation rate $(0.26 \pm 0.07$ ova per generation $)$ after eight generations of selection. Also, an increase of $7.87 \%$ was observed in prenatal survival. Effectiveness of the two-stage selection in pigs encouraged performing the same selection procedure in rabbits.

\subsection{RELEVANT FINDINGS}

\subsubsection{Selection for ovulation rate}

After six generations of selection for ovulation rate, the direct genetic response was 1.44 ova ( 0.24 ova per generation) and a correlated response of 0.07 kits per generation was obtained in litter size (Chapter 3). Low response on litter size can be explained by the negative genetic response on prenatal survival (-0.02 after six generations of selection). Similar results were reported by Cunningham et al. (1979), Leymaster and Christenson (2000) and Rosendo et al. (2007) in pigs and by Bradford (1969) in mice. This low correlated response on litter size may be attributed to the limitation of uterine capacity which led to an increase in prenatal mortality when ovulation rate increases. Overcrowded uterine horns were achieved when ovulation rate is high in both ovaries and then uterine capacity can be expressed.

Prenatal survival showed a negative response mainly due to a reduction in foetal survival (-0.04 after six generations of selection). As expected, similar results were 
obtained for foetal survival after 10 generations of selection for ovulation rate (Laborda et al., 2011 and 2012 a,b) since the first six generations were shared between both experiments. Laborda et al. (2011 and 2012a) proposed possible causes for this mortality accompanying with the increased ovulation rate:

1) Ovulation of immature oocytes.

2) Increase of ovulation timing which led to variation in embryonic development and caused foetal losses as a result of the asynchrony between the foetal development and maternal uterus status.

3) Foetal losses from the competence for space and nutrients in overcrowded uterine horn.

\section{High ovulation rate and prenatal mortality}

The available information about magnitude and timing of prenatal mortality in rabbits after selection for ovulation rate is insufficient. Van der Waaij et al. (2010) proposed to investigate the influence of high ovulation rate on foetal and placental development through gestation using hormonal treatment. Even though selection is likely to change other aspects of the uterine capacity and foetal characteristics, hormonally induced superovulation could provide some insight in the negative consequences of further increased ovulation rate. Therefore, an experiment was performed using hormonal treatment as a model for ovulation rate selection experiment (chapter 5).

An increase of 2.1 ova (Laborda et al., 2012b) was achieved after 10 generations of selection for ovulation rate using a control population. A low concentration of eCG (Mehaisen et al., 2005) was used to achieve a similar increase in ovulation rate. Difference of three ova was obtained between hormonal treated and untreated females using $50 \mathrm{UI}$ of eCG. Thus, the increase in ovulation rate using this hormone and dose 
could be a good model to provide some insight into the negative consequences on prenatal survival due to increased ovulation rate after direct selection during the first period of selection presented in this thesis (chapter 3) and after 10 generations of selection by ovulation rate published by Laborda et al. (2011).

Prenatal survival at day 18 of gestation for treated females was lower (0.12) than untreated females. Prenatal survival is composed of survival rate at the embryonic period (from ovulation to implantation at day 7) and foetal period (after implantation). For the embryonic period, lower embryo survival was obtained in treated females (0.10). Similar results were obtained in selected females for ovulation rate compared to the control one in rabbits (Laborda et al., 2012b). Embryonic mortality includes fertilization failure and embryonic losses. No difference in number of implanted embryo between treated and untreated females were found. Assuming that fertilization rate is high (near $100 \%$ ), like in untreated females (Adams, 1960a; Torrès et al., 1984; Santacreu et al., 1990), lower embryo survival in treated females can be attributed to the increase in ovulation rate. One of the possible reasons for the lower embryo survival could be a higher proportion of immature ova in the treated females. Koenig et al. (1986) found a higher proportion of immature ova in selected females for high ovulation rate compared to unselected females, and also in superovulated females compared to naturally ovulated ones; they suggested that immaturity of ova may cause a proportion of prenatal mortality either before or after implantation in gilts with high ovulation rate. As it was mentioned in chapter 3 , an increase in the number of ova shed may also cause longer ovulation process timing, producing higher variability in embryonic development. Asynchrony between embryonic development and oviduct and/or uterine secretions can cause embryo mortality (Wintenberger-Torres, 1974; Torres et al., 1987). 
Period from 12 to 18 days of gestation is a critical period for foetal survival because the placenta begins controlling foetal nutrition (Adams, 1960b). In agreement, the main difference in foetal survival between treated and untreated females appeared from 12 to $18 \mathrm{~d}$ of gestation (0.09). Several authors stressed that foetal mortality could increase when overcrowding was achieved due to the competence between fetuses for uterine space and resources. Since no difference in implanted embryos between treated and untreated females was found, higher foetal mortality in treated females cannot be attributed to higher competition among fetuses. Difference in foetal survival could be due to the same causes quoted before to explain differences obtained in embryo survival.

\section{Selection for ovulation rate and litter size}

Low genetic response on litter size was obtained after selection for ovulation rate supported changing the selection criteria to improve litter size more efficiently. Selection was performed using the independent culling levels to select females depending on ovulation rate and litter size. Females with the highest ovulation rate were selected. Within this group of selected females, selection was made for the mean litter size of the first two parities. Selection was done for 11 generations.

Selection for ovulation rate and litter size in the second period results in:

- $\quad$ Direct response on ovulation rate was produced, but with lower response $(0.17$ ova per generation) than the first six generations ( 0.24 ova per generation; chapter 3$)$.

- $\quad$ Direct response on litter size was higher ( 0.17 kits per generation) than the first six generations (0.07 per generation; chapter 3$)$.

- $\quad$ Positive correlated response on growth traits.

Response on ovulation rate was similar to the unique two-stage selection for ovulation rate and litter size performed in pigs (Ruiz-Flores and Johnson, 2001). A 
relevant response on litter size was achieved, 0.17 kits per generation, being lower than the obtained in pig two-stage experiment. Therefore, selection for two-stage for ovulation rate and litter size could be a way to improve litter size more effectively than direct selection, which achieved an improvement of around 0.10 kits per generation (reviews by Blasco et al., 1996 and García and Baselga, 2002a). Further research is needed to assess the use of this selected line for rabbit meat production. The cost of laparoscopy to measure ovulation rate should be taken into account in this evaluation although this cost will probably be unimportant because it is divided by the total litters produced by the nucleus females, representing a small part of the cost of the rabbit sold to the slaughterhouse. On the other hand, it should be considered that estimated response could be biased, mixed model methodology permits to estimate the response although the estimations are strongly dependent on the genetic parameters used in the model and estimations tend to be buoyant.

The higher response on litter size was mainly attributed to the enhancement on its components (ovulation rate and prenatal survival). The improvement in prenatal survival was achieved by an increment of both embryo and foetal survival and it could be related to an improvement in uterine capacity. Uterine capacity is defined as the maximum number of foetus that a female can support until parturition when ovulation rate is not a limiting factor. Due to the increase in ovulation rate achieved by selection (three ova at the end of both periods of selection), the percentage of females with a high ovulation rate was increased, and therefore a higher number of females could express their uterine capacity. Then, selection for litter size could improve uterine capacity by both embryo and foetal survival. 
Correlated response on number of born alive, number of kits at weaning and at marketing was estimated, assessing the proposal that selection by two-stage could be a way to improve litter size more efficiently than direct selection.

No clear pattern for correlated response on growth traits was found when using litter size as selection criteria in rabbits (Rochambeau, 1998; García and Baselga, 2002c; Mínguez et al., 2016). Besides, a correlated response on growth traits was observed in a line selected for ovulation in rabbits (Quirino et al., 2009) and in pigs (Rosendo et al., 2007). In agreement with these last results regarding to the effect of selection for ovulation rate, a positive correlated response on weaning weight, marketing weight and growth rate was found in both periods of selection. The correlated response during the first period was higher than during the second one for all growth traits in agreement to the higher genetic improvement in ovulation rate in the first period of selection ( 0.24 and 0.17 ova for the first and second period of selection, respectively). Therefore, the higher correlated response on marketing weight could be due to the estimated positive and moderate genetic correlation with ovulation rate (0.38). Correlated response on weaning weight could be explained by the positive and high genetic correlation between both weights. Another possible explanation for the correlated response on growth traits could be an unintentional selection for growth traits when future breeding animals were selected for ovulation and litter size traits.

Consequences of the increase of growth traits in maternal lines are not well known. A reduction in the fattening period to achieve the commercial weight implies a lower maintenance cost but also lower carcass yield. Besides, a correlated response on adult weight could be accomplished without knowledge of its consequences since it is unknown the optimum adult weight to achieve the maximum benefit for this reproductive line in a three way crosses. 
Summarizing, selecting for two-stage for ovulation rate and litter size could be a way to improve litter size more effectively than direct selection. Further studies to know better the consequences of increasing ovulation rate and which factors determine uterine capacity are needed. Besides, an evaluation of the reproductive performance of line OR-LS in a three way crosses scheme would be suitable before it can be recommended for commercial production.

\subsection{REFERENCES}

Adams, C. E. (1960a). Prenatal mortality in the rabbit Oryctolagus cuniculus. Journal of Reproduction and Fertility, 1: 36-44.

Adams, C. E. (1960b). Studies on prenatal mortality in the rabbit, Oryctolagus cuniculus: the amount and distribution of loss before and after implantation. Journal of Endocrinology, 19: 325-344.

Bakker, H., J. H. Wallinga and R. D. Politiek (1978). Reproduction and body weight of mice after longterm selection for large litter size. Journal of Animal Science, 46: $1572-1580$.

Baselga, M. (2004). Genetic improvement of meat rabbits. Programs and diffusion. In: Proceeding $8^{\text {th }}$ World Rabbit Congress, Puebla, Mexico. Volume 1: 1-13.

Blasco, A., J. A. Ortega, M. A. Santacreu and A. Climent (2005). Divergent selection for uterine capacity in rabbits. I. Genetic parameters and response to selection. Journal of Animal Science, 83: 2297-2302.

Blasco, A., J. P. Bidanel, G. Bolet, C. Haley, and M. A. Santacreu (1993). The genetics of prenatal survival of pigs and rabbits, a review. Livestock Production Science, 37: $1-21$. 
Blasco, A., P. Dando, J. Gogue and J. P. Bidanel (1996). Relationships between ovulation rate, prenatal survival and litter size in French Large White Pigs. Animal Science, 63: 143-148.

Bolet, G., L. Ollivier and P. Dando (1989). Sélection sur la prolificité chez le porc. I. Résultats d'une expérience de sélection sur onze générations. Genetics Selection Evolution, 21: 93-106.

Bolet, G., M. A. Santacreu, M. J. Argente, A. Climent and A. Blasco (1994). Divergent selection for uterine capacity in unilaterally ovariectomized rabbits. I. Phenotypic and genetic parameters. In: Proceeding $5^{\text {th }}$ World Congress on Genetics Applied Livestock Production, Guelph, Canada. Volume 19: 261-264.

Bradford, G. E. (1968). Selection for litter size in mice in the presence and absence of gonadotropin treatment. Genetics, 58: 283-295.

Bradford, G. E. (1969). Genetic control of ovulation rate and embryo survival in mice. I. Response to selection. Genetics, 61: 907-918.

Cunningham, P. J., M. E. England, L. D. Young and D. R. Zimmerman (1979). Selection for ovulation rate in swine: Correlated response in litter size and weight. Journal of Animal Science, 48: 509-516.

Falconer, D. S. (1971). Improvement of litter size in a strain of mice at a selection limit. Genetics Research, 17: 215-235.

Falconer, D. S. and T. F. C. Mackay (1996). Correlated characters. In: Introduction to quantitative genetics. Prentice Hall, Essex, England. Pages: 312-334.

García, M. L. and M. Baselga (2002a). Estimation of genetic response to selection in litter size of rabbits using a cryopreserved control population. Livestock Production Science, 74: 45-53. 
García, M. L. and M. Baselga (2002c). Estimation of correlated response on growth traits to selection in litter size of rabbits using a cryopreserved control population and genetic trends. Livestock Production Science, 78: 91-98.

García, M. L. and M. Baselga. (2002b). Genetic response to selection for reproductive performance in a maternal line of rabbits. World Rabbit Science, 10: 71-76.

Gion, J. M., A. C. Clutter and M. K. Nielsen (1990). Alternative methods of selection for litter size in mice: II. Response to thirteen generations of selection. Journal of Animal Science, 68: 3543-3556.

Holl, J. W., and O. W. Robison (2003). Results from nine generations of selection for increased litter size in swine. Journal of Animal Science, 81: 624-629.

Johnson, R. K., D. R. Zimmerman and R. J. Kittok (1984). Selection for components of reproduction in swine. Livestock Production Science, 11: 541-558.

Johnson, R. K., M. K. Nielsen and D. S. Casey (1999). Response in ovulation rate, embryonal survival and litter size traits in swine to 14 generations of selection to increase litter size. Journal of Animal Science, 77: 541-557.

Kirby, Y. K. and M. K. Nielsen (1993). Alternative methods of selection for litter size in mice: III. Response to 21 generations of selection. Journal of Animal Science, 71: $571-578$.

Koenig, J. L. F., D. R. Zimmerman F. E. Eldrige and J. D. Kopf (1986). The effect of superovulation and selection for high ovulation rate on chromosomal abnormalities in swine ova. Journal of Animal Science, 63 (Suppl. 1): 202.

Laborda, P., M. A. Santacreu, A. Blasco and M. L. Mocé (2012a). Selection for ovulation rate in rabbits: direct and correlated responses estimated with a cryopreserved control population. Journal of Animal Science, 90: 3392-3397. 
Laborda, P., M. L. Mocé, A. Blasco and M. A. Santacreu (2012b). Selection for ovulation rate in rabbits: genetic parameters and correlated responses on survival rates. Journal of Animal Science, 90: 439-446.

Laborda, P., M. L. Mocé, M. A. Santacreu and A. Blasco (2011). Selection for ovulation rate in rabbits: I. genetic parameters, direct response and correlated response on litter size. Journal of Animal Science, 89: 2981-2987.

Land, R. D. and D. S. Falconer (1969). Genetic studies of ovulation rate in the mouse. Genetical Research, 13: 25-46.

Leymaster, K. A. and R. K. Christenson (2000). Direct and correlated responses to selection for ovulation rate or uterine capacity in swine. Journal of Animal Science, 78 (Suppl.1): 68.

Mehaisen, G. M., J. S. Vicente, R. Lavara and M. P. Viudes-de-Castro (2005). Effect of eCG dose and ovulation induction treatments on embryo recovery and in vitro development post-vitrification in two selected lines of rabbit does. Animal Reproduction Science, 90: 175-184.

Mínguez, C., J. P. Sánchez, A. G. El Nagar, M. Ragab and M. Baselga (2016). Growth traits of four maternal lines of rabbits founded on different criteria: comparisons at foundation and at last periods after selection. Journal of Animal Breeding and Genetics, 133: 303-315.

Mocé, L., M. A. Santacreu, A. Climent and A. Blasco (2005). Divergent selection for uterine capacity in rabbits. III. Responses on uterine capacity and its components estimated with a cryopreserved control population. Journal of Animal Science, 83: $2308-2312$. 
Ollivier, L., and G. Bolet. (1981). Selection for prolificacy in the pig: results of a ten generation selection experiment. Annales de Zootechnie, 30: 382.

Quirino, C. R., R. Peiró, M. A. Santacreu and A. Blasco (2009). Genetic correlation between liveweight and ovulation rate in rabbits. In: Proceeding $60^{\text {th }}$ Annual Meeting of European Association of Animal Science, Barcelona, Spain. Volume 1: $1-5$.

Ribeiro, E. L., M. K. Nielsen, G. L. Bennett and K. A. Leymaster (1997). A simulation model including ovulation rate, potential embryonic viability, and uterine capacity to explain litter size in mice: I. Model development and implementation. Journal of Animal Science, 75: 641-651.

Rochambeau, H. de, R. Duzert and F. Tudela (1998). Long term selection experiment in rabbit. Estimation of genetic progress on litter size at weaning. In: Proceeding $\sigma^{\text {th }}$ World Congress on Genetics Applied to Livestock Production, Armidale, Australia. Volume 26: 112-115.

Rosendo, A., T. Druet, J. Gogue and J.P. Bidanel (2007). Direct response to six generations of selection for ovulation rate or prenatal survival in large white pigs. Journal of Animal Science, 85: 356-364.

Ruíz-Flores, A., and R. K. Johnson. (2001). Direct and correlated responses to twostage selection for ovulation rate and number of fully formed pigs at birth in swine. Journal of Animal Science, 79: 2286-2297.

Santacreu, M. A., L. Mocé, A. Climent and A. Blasco (2005). Divergent selection for uterine capacity in rabbits. II Correlated response on litter size and its components estimated with a cryopreserved control population. Journal of Animal Science, 83: 2303-2307. 
Santacreu, M. A., P. Viudes and A. Blasco (1990). Evaluation par coelioscopie des corps jaunes et des embryons. Influence sur la taille de portée chez la lapine. Reproduction Nutrition Development, 30: 583-588.

Torrès, S., F. Hulot and M. Meunier (1984). Étude comparée du développement et de la mortalité embryonnaire chez deux genotypes de lapines. In: Proceeding $3^{\text {rd }}$ World Rabbit Congress, Rome, Italy. Volume 2: 417-425.

Torrès, S., F. Hulot, M. Meunier and C. Sevellec (1987). Comparative study of preimplantation development and embryonic loss in two rabbit strains. Reproduction Nutrition Development, 27: 707-714.

Van der Waaij, E. H., W. Hazeleger, N. M. Soede, B. F. A. Laurenssen and B. Kemp (2010). Effect of excessive, hormonally induced intrauterine crowding in the gilt on fetal development on d 40 of pregnancy. Journal of Animal Science, 88: 26112619.

Wintenberger-Torres, S. (1974). Relation entre la taille des blastocystes de lapine a l'implantation et la survie embryonnaire. Annales de Biologie Animale, Biochimie, Biophysique, 14: 41-52. 
CHAPTER SEVEN

CONCLUSIONS 



\section{Genetics and environmental parameters}

- Estimated heritability of litter size and its components, ovulation rate, implanted embryos and survival traits were low to moderate, from 0.07 to 0.25 in agreement with previous results in rabbits.

- Survival rates showed moderate to high positive genetic correlation with LS (from 0.47 to 0.81 ), and moderate to low negative genetic correlation with OR (0.46 to -0.08$)$.

- Estimated heritability of growth traits (weaning weight, marketing weight and growth rate) was low, from 0.09 to 0.14 .

- Growth traits were no related genetically with LS and showed low or moderate positive genetic correlation with OR (from 0.19 to 0.38 ).

- Low environmental maternal effect $(0.11,0.05$ and 0.01$)$ and moderate environmental common litter effect $(0.35,0.28$, and 0.27$)$ were estimated for WW, MW and GR. Both environmental effects of dam decrease from weaning to 63 days, which corresponds to marketing weight.

\section{Response to selection}

- Selection for ovulation rate led to direct response of 0.24 ova per generation and a correlated response of $0.07 \mathrm{kits} /$ generation in LS due to a decrease in prenatal survival mainly because of a decrease in foetal survival (-0.02 and -0.04 , respectively).

- Selection for ovulation rate and litter size reduced the response on OR to 0.17 ova per generation, but the response on LS increased up to 0.17 kits per generation.

- Correlated response on NBA, NW and NM (0.12, 0.12 and 0.11 kits per generation, respectively) were also found in agreement with positive and high 
genetic correlation between LS and those traits $(0.89,0.81$ and 0.78 , respectively).

- Similar correlated response was obtained in NBD in both periods.

- $\quad$ Response on LS was due to an improvement of both ovulation rate (1.84 ova) and prenatal survival $(0.10)$ when two-stage selection for LS and OR were performed. Improvement in prenatal survival was due to an increase in embryo survival (0.04) and in foetal survival (0.03).

- Correlated response in both periods were obtained for growth traits; WW, MW and GR. An improvement of 0.7 and $0.5 \%$ for MW were achieved in each period, respectively. These improvement could be due to moderate correlation between MW and OR and/or for unintentional selection for growth traits when future breeding animals were selected for reproductive traits.

\section{High ovulation rate and prenatal mortality}

- The effect of increasing 3 ova by hormonal treatment leaded to a lower embryo and foetal survival at 18 days of gestation in treated females.

- Most of foetal mortality occurred during the early foetal period after day 12 of gestation; it is a critical period for foetal survival because the placenta begins controlling foetal nutrition.

- For weight of live foetuses, differences between treated and untreated females were found, although the estimation had a low accuracy. Unexpectedly, foetal placenta weight of live foetuses in the treated females was heavier than in untreated ones.

- A moderate increase of ovulation rate using 50 IU of equine chorionic gonadotropin (eCG) could be a good model to assess the timing of prenatal 
mortality to provide some insight on the negative consequences on prenatal survival due to increased ovulation rate by selection. 